\title{
Water-Level Variations and Their Effects on Tree Growth and Mortality and on the Biogeochemical System at the Phytoremediation Demonstration Site in Fort Worth, Texas, 1996-2003
}

By Christopher L. Braun, Sandra M. Eberts, Sonya A. Jones, and Gregory J. Harvey

In cooperation with the U.S. Air Force, Aeronautical Systems Center,

Environmental Management Directorate, Wright-Patterson Air Force Base, Ohio

Scientific Investigations Report 2004-5107 


\title{
U.S. Department of the Interior Gale A. Norton, Secretary
}

\author{
U.S. Geological Survey \\ Charles G. Groat, Director
}

\section{U.S. Geological Survey, Reston, Virginia: 2004}

For sale by U.S. Geological Survey, Information Services

Box 25286, Denver Federal Center

Denver, CO 80225

For more information about the USGS and its products:

Telephone: 1-888-ASK-USGS

World Wide Web: http://www.usgs.gov/

Any use of trade, product, or firm names in this publication is for descriptive purposes only and does not imply endorsement by the U.S. Government.

Although this report is in the public domain, permission must be secured from the individual copyright owners to reproduce any copyrighted materials contained within this report.

Braun, C.L., Eberts, S.M., Jones, S.A., and Harvey, G.J., 2004, Water-level variations and their effects on tree growth and mortality and on the biogeochemical system at the phytoremediation demonstration site in Fort Worth, Texas, 1996-2003: U.S. Geological Survey Scientific Investigations Report 2004-5107, 39 p. 


\section{Contents}

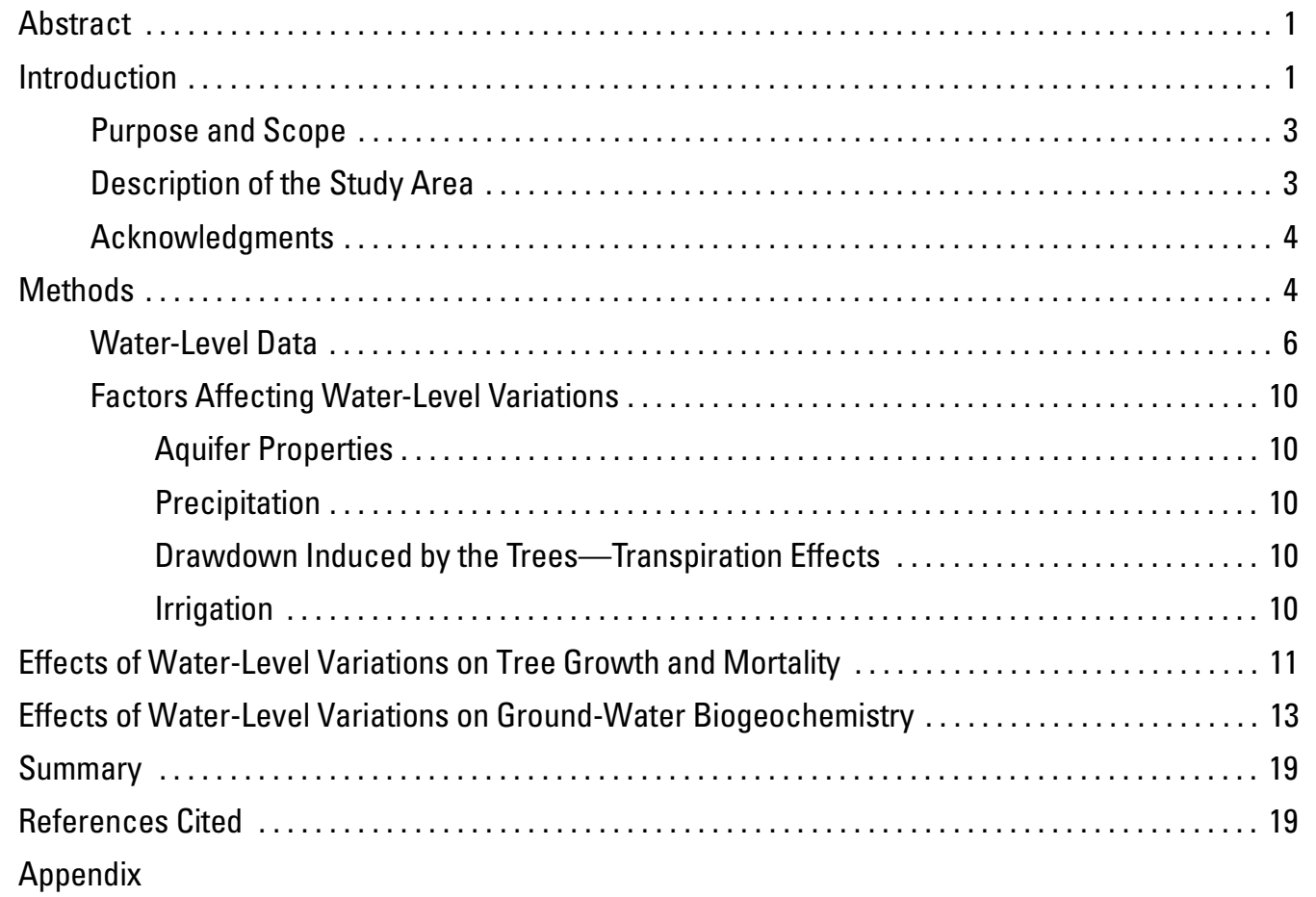

Figures-Maps showing (a) lines of equal ground-water depths and (b) water-level altitude contours for

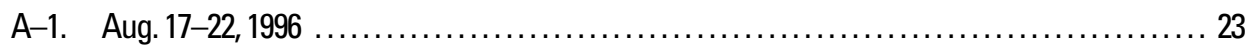

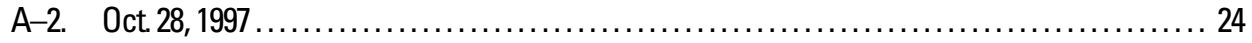

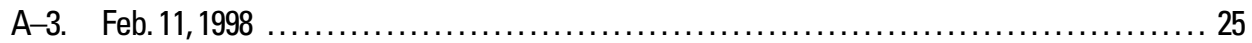

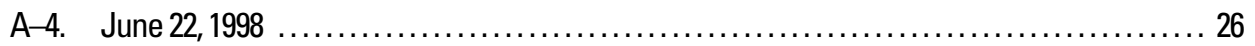

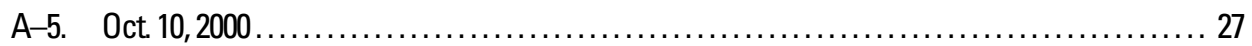

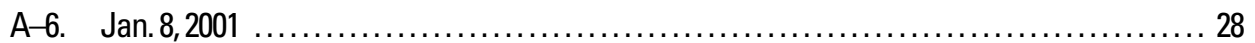

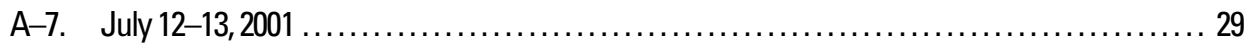

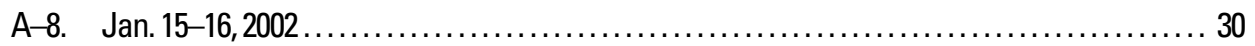

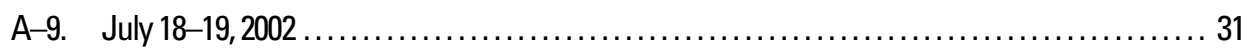

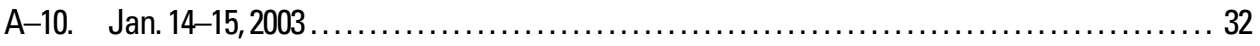

Tables

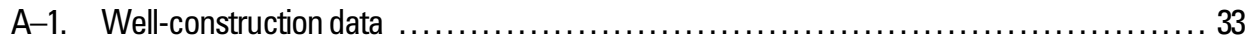

A-2. Trichloroethene concentrations from six sampling events $\ldots \ldots \ldots \ldots \ldots \ldots \ldots \ldots \ldots \ldots \ldots \ldots \ldots \ldots \ldots \ldots \ldots \ldots$

A-3. cis-Dichloroethene concentrations from six sampling events ...................... 36

A-4. Molar ratios of trichloroethene to cis-dichloroethene from six sampling events ........... 37

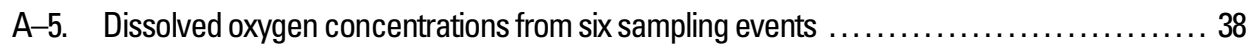

A-6. Dissolved organic carbon concentrations from September 2000 sampling event ......... 39

A-7. Quality-control results for trichloroethene (TCE), cis-dichloroethene (cis-DCE), and molar ratios of TCE to cis-DCE (TCE/cis-DCE) for four of six sampling events ............. 39 


\section{Figures}

1-5. Maps showing:

1. Location of study area, alluvial aquifer ground-water-flow directions, and

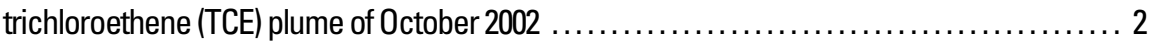

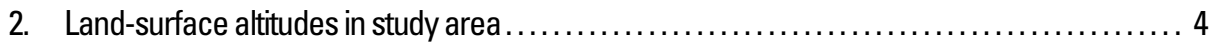

3. Location of wells within the study area and location of low hydraulic conductivity

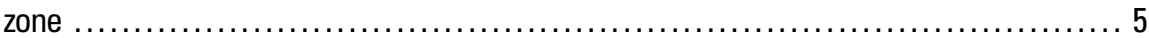

4. Location and relative diameter of existing trees, January 2003, and relations between mean tree diameter and ground-water depth (September 2000) and between mortality and ground-water depth (September 2000) within the whip plantation .................. 7

5. Location and relative diameter of existing trees and location of trees stunted by beaver activity within the caliper plantation, January $2003 \ldots \ldots \ldots \ldots \ldots \ldots \ldots \ldots \ldots$

6. Graphs showing daily mean water-level altitudes for wells 513,514 , and 515 , daily mean stream stage at Farmers Branch Creek, and monthly precipitation at Naval Air Station-Joint Reserve Base Carswell Field, November 1998-August 2002

7-11. Maps showing:

7. Estimated drawdown attributed to planted trees, June 22, 1998 11

8. Estimated drawdown attributed to planted trees, September 19-20, 2000 .... 12

9. Lines of equal ground-water depths and (a) molar ratio of trichloroethene (TCE) to cis-dichloroethene (cis-DCE), and (b) dissolved oxygen concentrations, June 22, 1998 ..... 14

10. Lines of equal ground-water depths and (a) molar ratio of trichloroethene (TCE) to cis-dichloroethene (cis-DCE), and (b) dissolved oxygen concentrations, January 8, 2001 .

11. Lines of equal ground-water depths and (a) molar ratio of trichloroethene (TCE) to cis-dichloroethene (cis-DCE), and (b) dissolved oxygen concentrations, July 12-13, 2001 ....

12. Boxplots showing distribution of (a) dissolved oxygen concentrations, September 2000July 2002, and (b) molar ratios of trichloroethene (TCE) to cis-dichloroethene (cis-DCE), September 2000-July 2002 for selected ground-water depths

13. Map showing location and relative diameter of remaining trees within the whip plantation near well 516, graphs of dissolved oxygen concentration and molar ratio of trichloroethene (TCE) to cis-dichloroethene (cis-DCE) from well 516 samples for selected sampling events, and graph of monthly precipitation from the nearby Naval Air Station-Joint Reserve Base Carswell Field

\section{Vertical Datum}

Vertical coordinate information is referenced to the North American Vertical Datum of 1988 (NAVD 88). 


\title{
Water-Level Variations and Their Effects on Tree Growth and Mortality and on the Biogeochemical System at the Phytoremediation Demonstration Site in Fort Worth, Texas, 1996-2003
}

\author{
By Christopher L. Braun ${ }^{1}$, Sandra M. Eberts ${ }^{1}$, Sonya A. Jones ${ }^{1}$, and Gregory J. Harvey ${ }^{2}$
}

\section{Abstract}

In 1996, a field-scale phytoremediation demonstration project was initiated and managed by the U.S. Air Force at a site in western Fort Worth, Texas, using a plantation of 1-year-old stems harvested from branches of eastern cottonwoods during the dormant season (whips) and a plantation of 1-year-old eastern cottonwood seedlings (calipers). The primary objective of the demonstration project was to determine the effectiveness of eastern cottonwoods at reducing the mass of dissolved trichloroethene transported within an alluvial aquifer. The U.S. Geological Survey conducted a study, in cooperation with the U.S. Air Force, to determine water-level variations and their effects on tree growth and mortality and on the biogeochemical system at the phytoremediation site. As part of the study, waterlevel and water-quality data were collected throughout the duration of the project.

This report presents water-level variations at periodic sampling events; data from August 1996 to January 2003 are presented in this report. Water levels are affected by aquifer properties, precipitation, drawdown attributable to the trees in the study area, and irrigation. This report also evaluates the effects of ground-water depth on tree growth and mortality rates and on the biogeochemical system including subsurface oxidation-reduction processes.

Overall, both whips and calipers showed a substantial increase in height, canopy diameter, and trunk diameter over the first 3 years of the study. By the fifth growing season (September 2000), the height of the calipers varied predictably with height decreasing with increasing depth to ground water. Percent mortality was relatively constant at about 25 percent in the whip plantation in January 2003 where ground-water levels were less than 10 feet below land surface during the drought in September 2000. The mortality rate increased where the

\footnotetext{
${ }^{1}$ U.S. Geological Survey.

${ }^{2}$ Environmental Management Directorate, Wright-Patterson Air Force Base, Ohio.
}

ground-water levels were greater than 10 feet below land surface and approached 90 percent where ground-water levels were between 12 and 13 feet.

A decrease in molar ratio of trichloroethene to cisdichloroethene was measured in ground water within and downgradient from the planted area over time. Decreases in these ratios appeared to be related to ground-water depth. The molar ratios of trichloroethene to cis-dichloroethene during the third growing season were relatively constant, between 3.0 and 4.0 , in samples collected from wells across the site. By the end of the fifth growing season the lowest ratio was measured in areas where ground-water depth was less than 10 feet below land surface; these same areas had the lowest dissolved oxygen concentrations ( 0.93 to 1.7 milligrams per liter) and the highest dissolved organic carbon concentrations (1.6 to 1.8 milligrams per liter). This indicates that between the third and fifth growing seasons, a labile fraction of dissolved organic carbon had been introduced into the aquifer by the planted trees that was capable of stimulating reductive dechlorination of trichloroethene.

\section{Introduction}

A field-scale phytoremediation demonstration project was initiated in 1996 by the U.S. Air Force at a site in western Fort Worth, Tex., near Air Force Plant 4 (AFP4) (fig. 1). The primary objective of the project was to determine the effectiveness of eastern cottonwoods (Populus deltoides) at reducing the mass of dissolved trichloroethene (TCE) that is being transported within an alluvial aquifer. TCE has been used at the site in aircraft manufacturing processes for decades; spills and leaks from TCE tanks within the manufacturing building have resulted in shallow ground-water contamination on-site and downgradient from the facility (Eberts and others, 2003). Before the development of the phytoremediation demonstration site, which is located 0.9 mile downgradient from the suspected source, natural attenuation of TCE at the site was limited to sorption, dispersion, dilution, and possibly volatilization. Some 

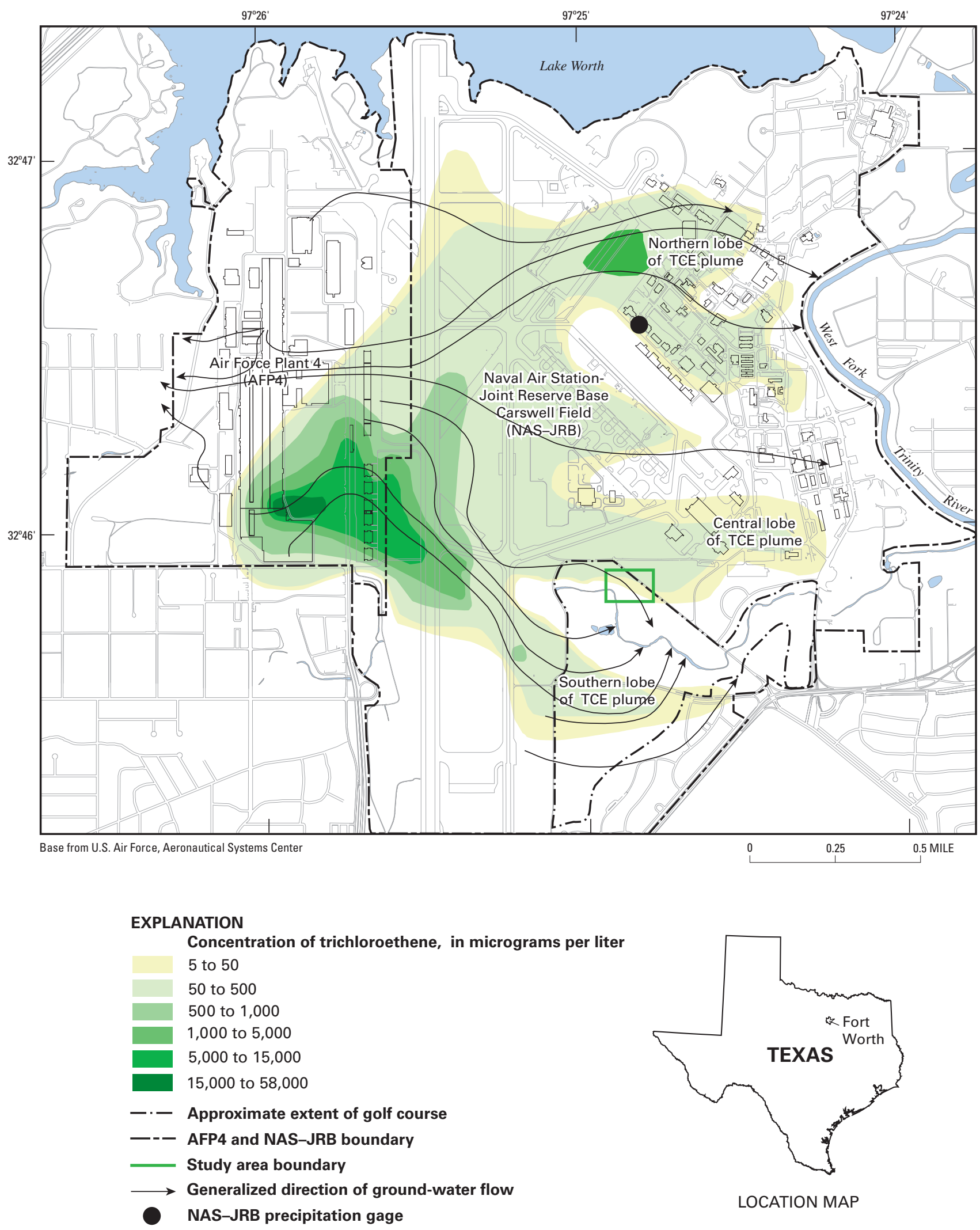

LOCATION MAP

Figure 1. Location of study area, alluvial aquifer ground-water-flow directions, and trichloroethene (TCE) plume of October 2002 (derived from data obtained from U.S. Air Force, Air Force Center for Environmental Excellence, 1997). 
in-place biodegradation of the plume might have occurred upgradient from the demonstration site (RUST Geotech, 1996). Background sampling and site characterization during 1996 indicated a lack of in-place TCE biodegradation at the site. Dissolved oxygen (DO) concentrations typically were greater than 5 milligrams per liter $(\mathrm{mg} / \mathrm{L})$, dissolved organic carbon (DOC) concentrations generally were less than $1.5 \mathrm{mg} / \mathrm{L}$, and ratios of TCE to its daughter products were relatively stable across the site (Jacobs Engineering Group Inc., 1996).

Carbon must be available as an electron donor for biodegradation of chlorinated solvents by means of reductive dechlorination to occur. DO is the first electron acceptor to be used, but once DO is depleted, anaerobic microorganisms tend to use available electron acceptors in the following order: nitrate, ferric iron, oxyhydroxide (from DO), sulfate, and carbon dioxide (Eberts and others, 2003). In the absence of DO or nitrate, chlorinated solvents might act as electron donors in place of ferric iron, sulfate, and carbon dioxide. Biodegradation of chlorinated solvents, such as TCE, tends to be limited by the availability of electron donors because the primary process in the biodegradation of chlorinated solvents under natural conditions is the use of chlorinated solvents as electron acceptors (Wiedemeier and others, 1996).

Eastern cottonwood trees, which are a type of poplar tree, have the potential to add organic carbon to ground water, which facilitates in-place microbial reductive dechlorination of TCE. According to Hansen (1993), a net addition of soil carbon occurs beneath poplar plantations with trees that are older than 6 to 12 years. Leigh and others (2002) suggest that root turnover can provide substrate for degradative bacteria, and Haycock and Pinay (1993) report that poplars in a riparian buffer strip in southern England contributed enough organic carbon to shallow ground water during winter months to cultivate anaerobic conditions and promote complete denitrification of dissolved nitrate. In addition to supporting in-place reductive dechlorination, phreatophytes such as eastern cottonwoods might remove contaminants from shallow ground water by various processes. Tree physiological processes might alter the flow of ground water and thereby reduce contaminant mobility by a process called phytostabilization. Plants and microbial enzymes can bind contaminants into soil by a process called humification. Once the contaminants have been removed from the aquifer through root systems, trees use enzymes to break down contaminants by a process called phytodegradation. Finally trees can remove contaminants by transpiration from leaf surfaces by a process called phytovolatilization (McCutcheon and Schnoor, 2003).

The demonstration project was initiated using a plantation of 1-year-old stems harvested from branches of eastern cottonwoods during the dormant season (whips) and a plantation of 1-year-old eastern cottonwood seedlings (calipers). The U.S. Geological Survey (USGS), in cooperation with the U.S. Air Force, collected water-level and water-quality data throughout the duration of the ongoing demonstration project; data from August 1996 to January 2003 are presented in this report. This study was conducted to determine water-level variations at the phytoremediation demonstration site and to determine the effects of the water-level variations on tree growth and mortality and on the biogeochemical system.

\section{Purpose and Scope}

This report documents water-level variations at the phytoremediation site during 1996-2003 and describes factors affecting water-level variations, such as aquifer properties, precipitation, drawdown attributable to trees, and irrigation. The effects of spatial changes in water-level altitudes and groundwater depth on tree growth and mortality during August 1996January 2003 are described. Changes in water-level altitudes at three instrumented wells during October 1998-July 2002 are presented, and these data are compared to the stage of a nearby creek and precipitation data over the same period of record. This report also presents an evaluation of the effects of groundwater depth on the biogeochemical system including subsurface oxidation-reduction processes that relate to TCE degradation.

\section{Description of the Study Area}

The study area is 25 acres and is located in the northwestern corner of a golf course in the southeastern part of the Naval Air Station-Joint Reserve Base Carswell Field (NAS-JRB) (fig. 1). The land surface slopes gently southeastward and sharply southwestward from Roaring Springs Road toward Farmers Branch Creek (fig. 2). The climate in the study area is subhumid, with short, mild winters (daily low temperature averaging about 34 degrees Fahrenheit $\left[{ }^{\circ} \mathrm{F}\right]$ in January) and generally long, hot summers (daily high temperature averaging about $96^{\circ} \mathrm{F}$ in July) (Kuniansky and others, 1996). Average annual temperature is $65^{\circ} \mathrm{F}$, and average annual precipitation is 32 inches (in.) (Kuniansky and others, 1996).

The phytoremediation demonstration site, which comprises the study area, is located in the central lobe (fig. 1) of a larger TCE ground-water plume that occurs in an alluvial aquifer and originates upgradient from the site at AFP4. When the demonstration project was initiated during spring 1996, the phytoremediation site consisted of a plantation of 1-year-old stems harvested from branches of eastern cottonwoods during the dormant season (whips) and a plantation of 1-year-old eastern cottonwood seedlings (calipers). Each plantation was about 235 feet (ft) long and $50 \mathrm{ft}$ wide and contained 7 rows of trees. About 60 trees were planted in each row of the whip plantation, and about 30 trees were planted in each row of the caliper plantation.

Thickness of the alluvial aquifer, which is composed of clayey sands and gravels, ranged from 6 to $15 \mathrm{ft}$, and saturated thickness ranged from 1.5 to $5 \mathrm{ft}$. A relatively impermeable, massively bedded, shaley limestone underlies the aquifer. The aquifer, which contains three permeable units (shallow, intermediate, and deep), is unconfined and very permeable. The general direction of ground-water flow in the alluvial aquifer at the site (fig. 3) is to the southeast, which is perpendicular to the long sides of the plantations, but locally ground water flows 


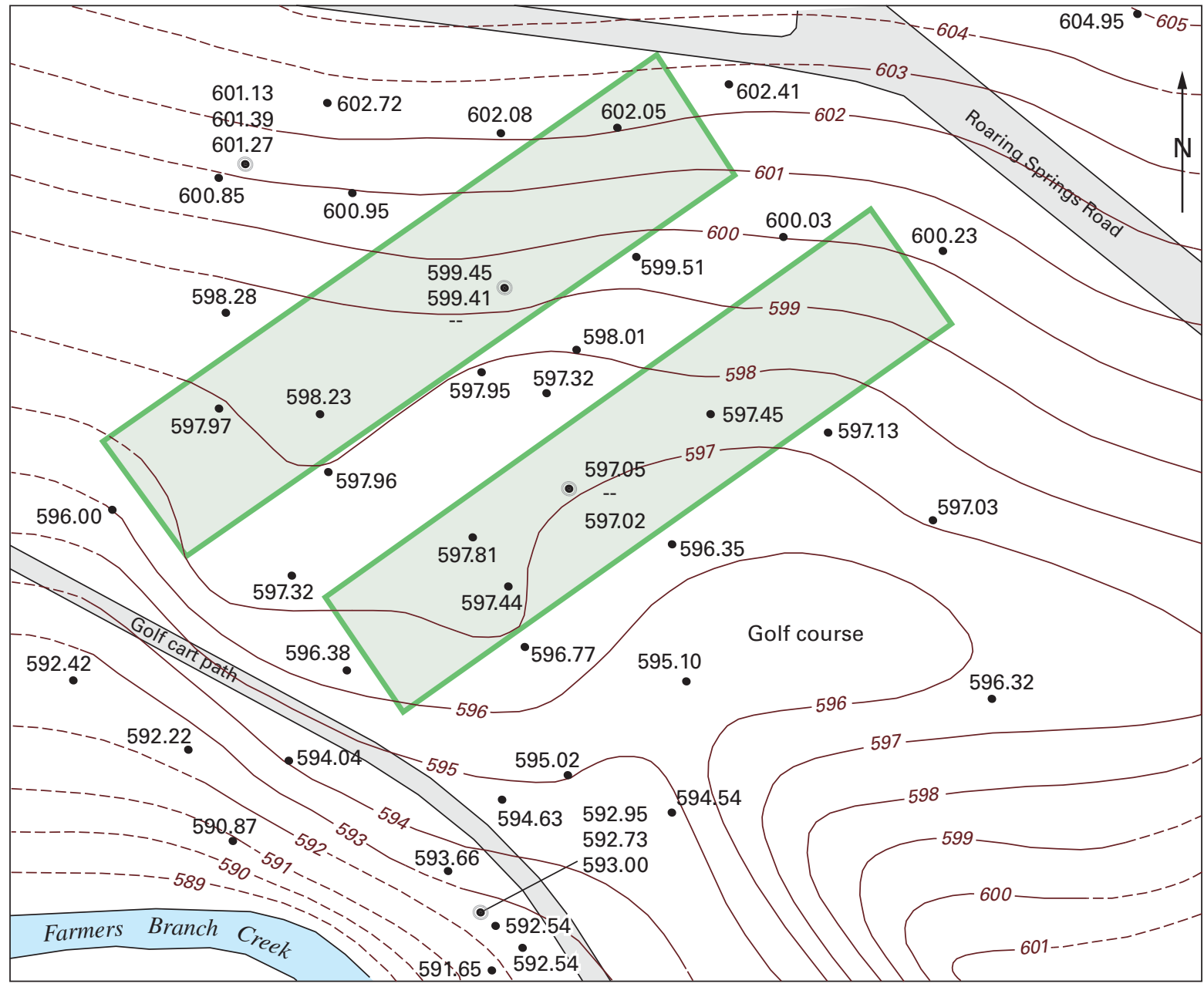

EXPLANATION

Approximate extent of tree plantations

-605- Topographic contour-Shows altitude of land surface, in feet above NAVD 88. Contour interval 1 foot; dashed where inferred

$600_{23}$ Well-Number is altitude of land surface, in feet above NAVD 88

- Nested wells-Numbers are altitudes of land surface, in 599.45 feet above NAVD 88; --, not available 599.41

Figure 2. Land-surface altitudes in study area.

toward Farmers Branch Creek in the area southwest of the golf cart path. Ground-water depths ranged from 8 to $13 \mathrm{ft}$ below land surface at the time of site characterization (1996).

\section{Acknowledgments}

This study was supported by the Superfund Innovative Technology Evaluation Program of the U.S. Environmental Protection Agency, the Environmental Security Technology Certification Program of the Department of Defense, and the
Aeronautical Systems Center, Environmental Management Directorate, Wright-Patterson Air Force Base.

\section{Methods}

Planting techniques used at the site generally followed those established for short-rotation woody crops (Perlack and others, 1995). Seven rows were trenched in each plantation to a depth of $3 \mathrm{ft}$, with a spacing of $8 \mathrm{ft}$ between rows. Whips, which 


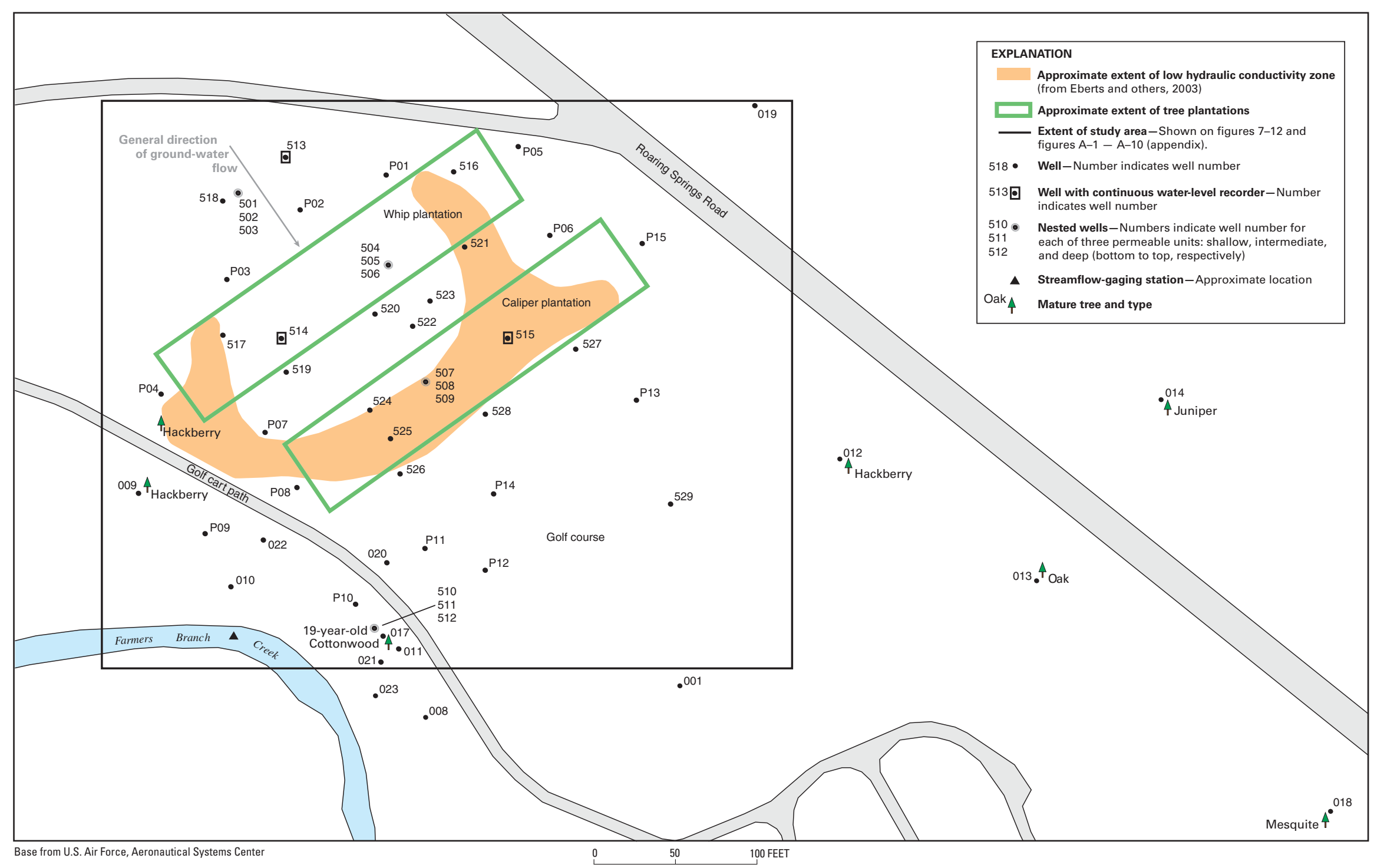

Figure 3. Location of wells within the study area and location of low hydraulic conductivity zone. 


\section{Water-Level Variations and Their Effects on Tree Growth and Mortality and on the Biogeochemical System, 1996-2003}

were about $1.5 \mathrm{ft}$ tall, were planted $4 \mathrm{ft}$ apart within rows, whereas calipers, which were greater than $6.5 \mathrm{ft}$ tall, were planted $8 \mathrm{ft}$ apart within rows. Irrigation lines and compost material were placed in the trenches. After trenches were backfilled, the whips extended 2 in. above the land surface.

The plantings, specifically for the whips, were closely spaced to allow for a "natural" self-design of the phytoremediation system. In other words, tree growth and survival were dependent upon subsurface heterogeneities. Closely spaced cottonwoods have been shown to have smaller diameters and lower survival rates than widely spaced cottonwoods (Krinard, 1985). This also was observed at the demonstration site. Whips, which were planted twice as closely as calipers, had both a higher mortality rate and a smaller relative diameter (fig. 4) than calipers (fig. 5). A drip irrigation system was used to supplement precipitation during the first two growing seasons, and trees were watered liberally during the first year, before continuous waterlevel measurements, to encourage development of deep roots. Trees were watered only once during 1997. During the first 3 years of the demonstration project, several tree properties were measured, including height, canopy diameter, and trunk diameter by Science Applications International Corporation (SAIC). Tree properties were not measured again until January 2003, when trunk diameter was measured by the USGS.

The monitoring system for the site was designed to measure incremental changes in site conditions because phytoremediation processes require years to develop. Groundwater-level data were collected from 15 piezometers and 44 wells, stream stage was measured in Farmers Branch Creek, and precipitation was measured at the NAS-JRB (National Climatic Data Center, 2002). All piezometers and wells are referred to as wells in this report. The wells were installed upgradient from, within, downgradient from, and surrounding the tree plantations. Several wells were installed adjacent to mature trees, including a 19-year-old (in 1996) cottonwood tree. Well depths ranged from 6.55 to $15.19 \mathrm{ft}$ below land surface. Twelve of the wells were installed to make four sets of nested wells with three wells in each nest. Each well within each nest was screened across one of three permeable units (shallow, intermediate, and deep) within the alluvial aquifer. All other wells were screened across all three units. Well-construction data are in the appendix (table A-1).

Most of the 59 wells were used primarily for measuring water levels. Land-surface altitudes at the wells were determined by automatic levels from a known benchmark. The horizontal accuracy of this method typically is within $0.03 \mathrm{ft}$ (D.S. Brown, U.S. Geological Survey, oral commun., 2004). Water levels in all wells were measured from the top of casing using an electric tape. In addition, transducers were placed in three wells to continuously measure and record water levels - one upgradient from the tree plantations (well 513), one in the whip plantation (well 514), and one in the caliper plantation (well 515) (fig. 3). Water-level-altitude data from the three instrumented wells (513, 514, and 515), stage data from Farmers Branch Creek, and monthly precipitation data from the
NAS-JRB are presented in figure 6 for the longest time interval that was common to all three datasets.

To assess geochemical changes within the aquifer that can be attributed to the planted trees, unfiltered ground-water samples were collected from wells using a peristaltic pump. Wells were pumped for at least 30 minutes before sampling. Ground-water samples were analyzed for DO and volatile organic compounds (VOCs) - TCE, cis-dichloroethene (cis-DCE), trans-dichloroethene (trans-DCE), and vinyl chloride (VC).

Decontamination procedures consisted of rinsing the sample cell used for collecting the DO sample with ground water from the well prior to sample collection. New Tygon tubing (having a low oxygen-diffusion coefficient) was used at each well.

During the study, methods for geochemical data collection and analysis changed, usually as a result of technological advancements. This invariably affects comparability of some datasets over time. The concentration of DO was measured in the field using the indigo carmine method (Gilbert and others, 1982). Before June 1998, DO was analyzed using a method of visual comparison to a standard for a concentration measurement. After June 1998, a photometer was used to provide a quantitative method for determining concentration. Before January 2000, VOCs were analyzed in the field using a Photovac $10 \mathrm{~S} 50$ gas chromatograph calibrated for TCE, cis-DCE, transDCE, and VC. All subsequent ground-water samples were analyzed in the laboratory by Severn Trent Laboratories (STL) in Arvada, Colo. Spatial variations in ratios of TCE to cis-DCE measured prior to January 2000 are useful, but the magnitude of the values is not directly comparable to data that were analyzed in the laboratory after January 2000. Water-quality results are listed in the appendix (tables A-2 - A-6).

Duplicate analyses were done on about 10 percent of well samples. Replicate samples from about 10 percent of total well samples also were sent to STL for analysis along with (typically) at least one trip blank. STL also analyzed method blanks and spikes to test for quality assurance and quality control within the laboratory (table A-7).

Geochemical data from May 1999, January 2000, and July 2000 are given less weight than other geochemical data in this report because water-level data were not collected during these sampling events.

\section{Water-Level Data}

Ground-water levels were measured in 59 wells upgradient from, within, downgradient from, and surrounding the tree plantations during August 1996, October 1997, February 1998, June 1998, September 2000, January 2001, July 2001, January 2002 , July 2002, and January 2003. These datasets were used to generate a series of maps of ground-water depth and water-level altitude, one for each of the measurement dates. The same datasets were used in conjunction with topographic data (fig. 2) to generate a series of water-level-altitude maps for the same time periods (appendix, figs. A-1 - A-10). Water levels were 


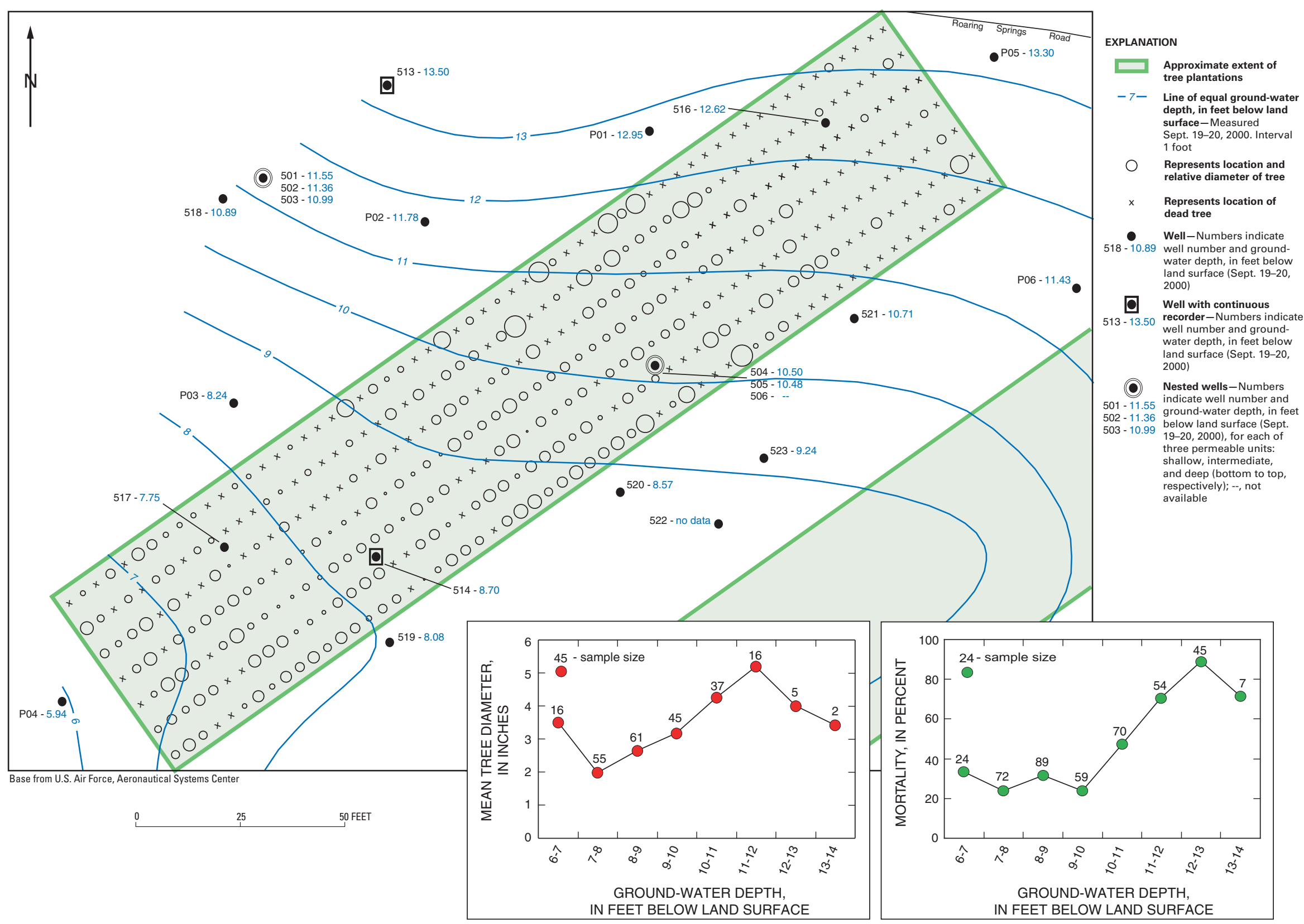

Figure 4. Location and relative diameter of existing trees, January 2003, and relations between mean tree diameter and ground-water depth (September 2000) and between mortality and ground-water depth (September 2000) within the whip plantation. 


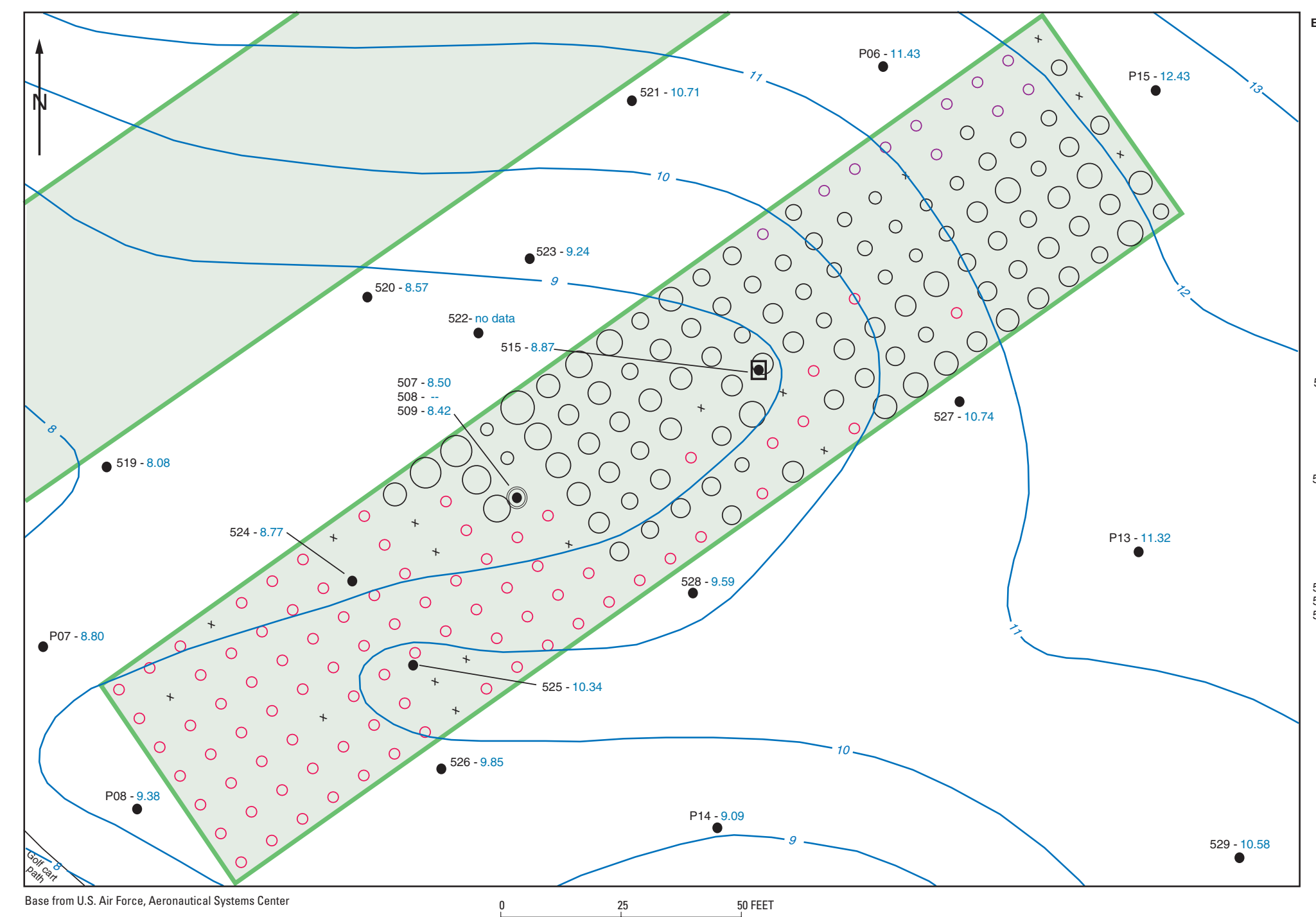

EXPLANATION

Approximate extent

$-7-$ Line of equal ground. water depth, in feet Measured Sept. 19-20, 2000
Interval 1 foot

Represents location and relative diameter

Represents location

- Represents location of a tree stunted by

Represents location Represents location
of a tree altered by human activity

$\bullet \quad$ Well-Numbers
$520-8.57$ indicate well number and ground-water depth, in feet below 19-20, 2000)

Dell with continuous indicate well number and ground-water
depth, in feet below land surface (Sept.

Nested wells

(9) Nested wells-
Numbers indicate $508-\ldots$ well number and
508 , ground-water depth,
in feet below land surface (Sept. 19-20,
2000 ), for each of three permeable units: shallow, intermediate,
and deep (bottom to top, respectively); top, respectively):
,- not available

Figure 5. Location and relative diameter of existing trees and location of trees stunted by beaver activity within the caliper plantation, January 2003. 

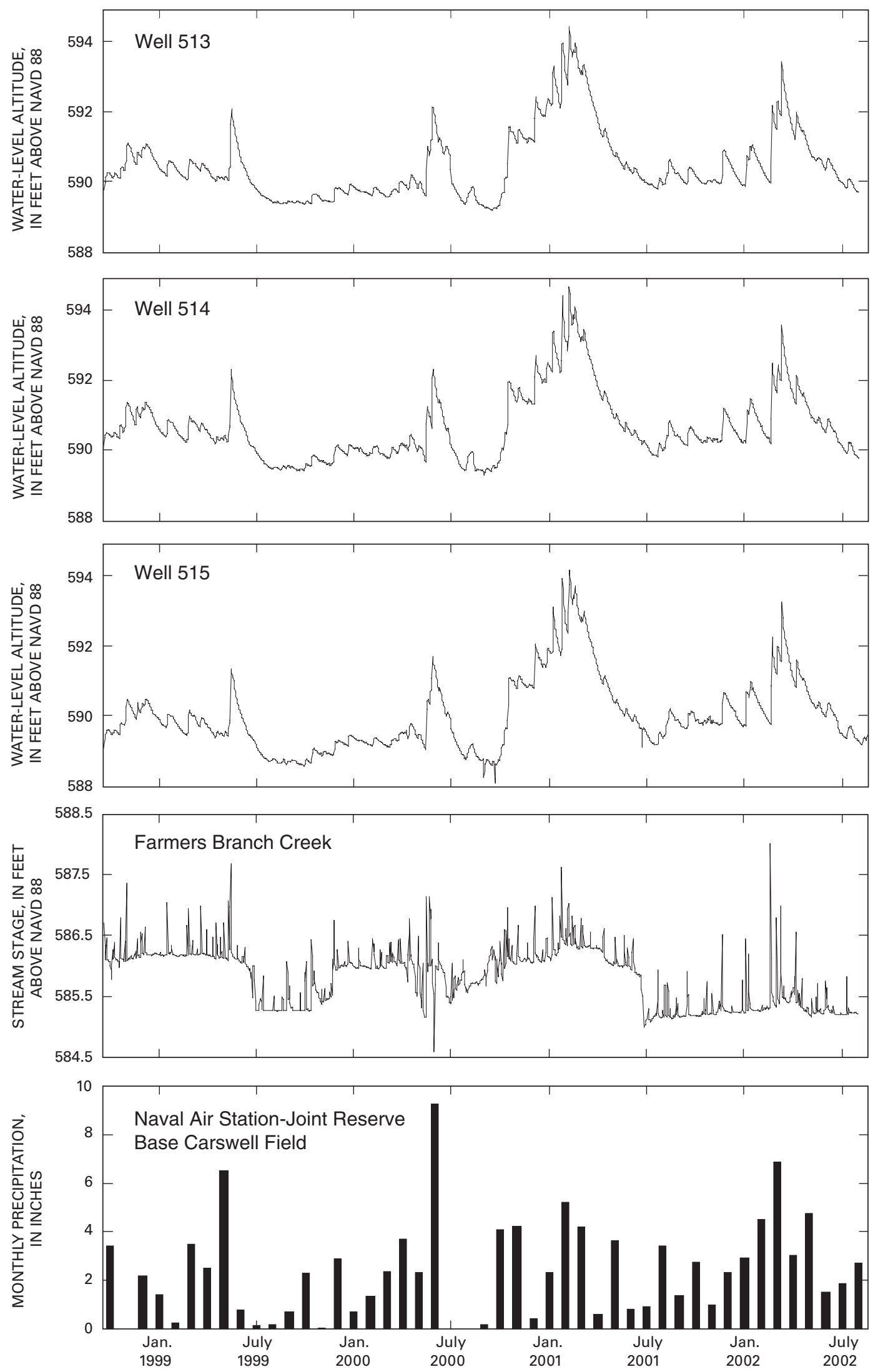

Figure 6. Daily mean water-level altitudes for wells 513, 514, and 515, daily mean stream stage at Farmers Branch Creek, and monthly precipitation at Naval Air Station-Joint Reserve Base Carswell Field, November 1998-August 2002. 
not measured in all wells during the first 2 years. Measurements for ground-water depth and water-level altitude at nested wells were not used directly in contouring. However, the range of measured water levels at nested wells was considered in contouring. For example, if water-level altitudes at a nest ranged from 590.73 to $590.96 \mathrm{ft}$, it was assumed that the actual waterlevel altitude at that point could not be outside that range. This same assumption was made with ground-water depths at nested wells. Measured ground-water depths and water-level altitudes at nested wells are shown in the appendix (figs. A-1 - A-10).

\section{Factors Affecting Water-Level Variations}

Water-level data were used to characterize water-level variations during 1996-2003. Three primary factors affect observed water levels in the study area: aquifer properties, precipitation, and drawdown induced by trees. Irrigation during the first two growing seasons also likely affected water levels indirectly by reducing the dependence of trees on water from the aquifer; however, technology is not in place to measure those effects.

\section{Aquifer Properties}

The alluvial aquifer, which is composed of clayey sands and gravels, is very thin and ranges from 6 to $15 \mathrm{ft}$ thick; saturated thickness ranges from 1.5 to $5 \mathrm{ft}$. The aquifer is unconfined and very permeable. The combination of these aquifer properties makes the water levels in the aquifer easily influenced by short-term stresses such as large amounts of precipitation.

\section{Precipitation}

Monthly precipitation data were obtained from a weather station at the nearby NAS-JRB (National Climatic Data Center, 2002). These data were compared to water-level-altitude data from the three instrumented wells $(513,514$, and 515) and stage data from Farmers Branch Creek to evaluate the relative effect that precipitation has on water-level variations at the site. There is a strong relation between precipitation and ground-water altitude at the site (fig. 6). Monthly precipitation totals in excess of 6 in. during May 1999, June 2000, and March 2002 appear as peaks in the hydrographs for wells 513, 514, and 515 and in the stage of Farmers Branch Creek; periods of substantially belownormal precipitation, referred to as droughts in this report, from July to September 2000 (0.19 in.) and from July to August 1999 (0.34 in.) appear as troughs. The highest water levels occurred during January-March 2001. Although this peak is coincident with moderately heavy precipitation (11.72 in. during that period), the magnitude of the peak is greater than peaks from May 1999, June 2000, and March 2002, which had comparable precipitation totals. Additional precipitation might have fallen during January-March 2001 in the contributing area to the site that was not observed at the NAS-JRB weather station.

\section{Drawdown Induced by the Trees-Transpiration Effects}

Drawdown maps were generated to estimate the effects of transpiration on ground-water levels. These maps were generated by comparing water levels measured in June 1998 (fig. 7) and September 2000 (fig. 8) with water levels measured in February 1998. Water levels measured in February 1998 were used in the comparison rather than water levels measured in August 1996 because 38 additional wells were installed in the area between August 1996 and February 1998, and these wells provided more control. Data from the additional wells helped to provide a more detailed picture of the drawdown cone. The February 1998 data also were used because they provided the largest available dormant-season dataset. A ground-water-flow model of the site (Eberts and others, 2003) indicated no remnant effects of tree transpiration on water-level altitudes during the dormant season.

Before drawdowns were computed, water levels in wells at the study site were normalized to water levels in wells in the surrounding area to account for temporal changes in the water table that were unrelated to the planted trees. Specifically, the water-level data were adjusted by an amount equal to the difference between water levels at the selected time (June 1998 or September 2000) and the water levels during February 1998 in wells that were outside the influence of the planted trees. After this normalization, the difference between the water levels during the period of interest and February 1998 was computed to approximate the drawdown that could be attributed to tree transpiration.

During the peak of the third growing season (June 1998), the maximum drawdown that could be attributed to trees, 4.0 to 4.9 in., was observed between the two plantations. Although a drawdown cone could be mapped at this time, the regional hydraulic gradient across the demonstration site was to the southeast (fig. 7). As a result, most contaminated ground water flowed past the downgradient end of the planted area. By the end of the fifth growing season (September 2000), both the magnitude and extent of the drawdown caused by the trees was apparent (fig. 8). Maximum observed drawdown in September 2000 was about 11.5 in., and the diameter of the drawdown cone for areas in which the drawdown exceeded 3.0 in. was about $525 \mathrm{ft}$.

\section{Irrigation}

A drip irrigation system was required to supplement precipitation during the first two growing seasons (1996-97). Water from the city was used to irrigate the trees during this period. Trees were watered liberally during the first year, before continuous water-level measurements, to encourage development of deep roots. Trees were watered only once during 1997. Roots were expected to intercept most or all percolating irrigation water (Licht and Madison, 1994); therefore, irrigation was not considered to be an additional source of water 


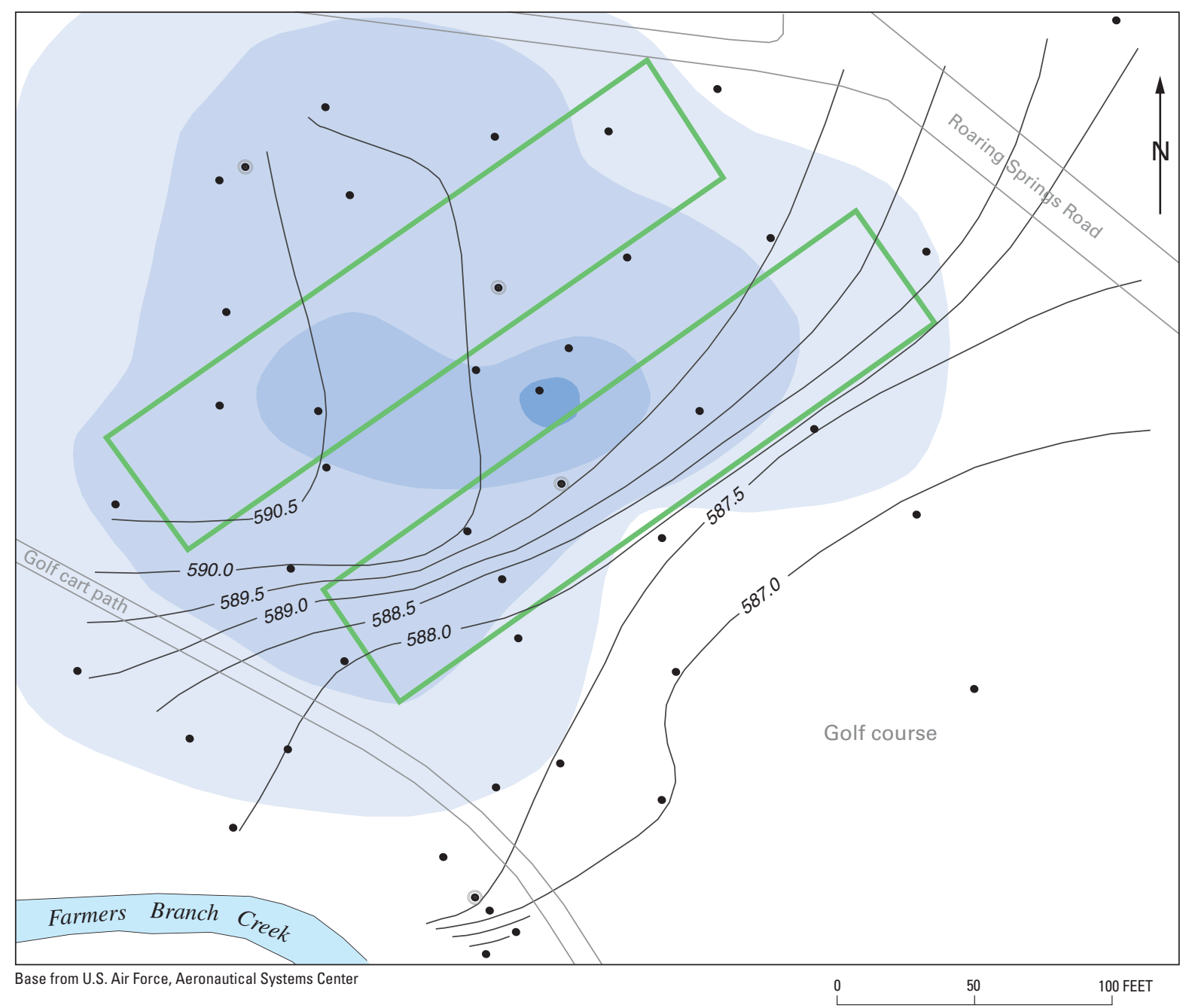

\section{EXPLANATION}

Estimated drawdown, in inches

Less than 0.9

1.0 to 1.9

2.0 to 2.9

3.0 to 3.9

4.0 to 4.9
Approximate extent of tree plantations

Water-table contour-Shows altitude of water table, in feet above NAVD 88. Contour interval 0.5 foot

- Well

- Nested wells

Figure 7. Estimated drawdown attributed to planted trees, June 22, 1998.

to the aquifer. However, irrigation might have caused a reduction in the volume of water extracted from the aquifer by the trees.

\section{Effects of Water-Level Variations on Tree Growth and Mortality}

Rates of tree growth at the site were documented to determine the effectiveness of the phytoremediation system. Fiftytwo whips and 51 calipers were measured for tree height, can- opy diameter, and trunk diameter several times during the first three growing seasons by SAIC. Overall, both whips and calipers showed a substantial increase in all properties measured. Only two of the 52 whips and three of the 51 calipers did not survive the first 3 years.

Mean trunk diameter increased from less than 1 in. to about 2 in. for the whips and from less than $1.5 \mathrm{in}$. to $3.15 \mathrm{in}$. for the calipers during the first 3 years of the study. Although the calipers generally were taller than the whips during the first growing season, by the end of the third growing season (1998), the whips were about equal to the calipers in height. The whips 


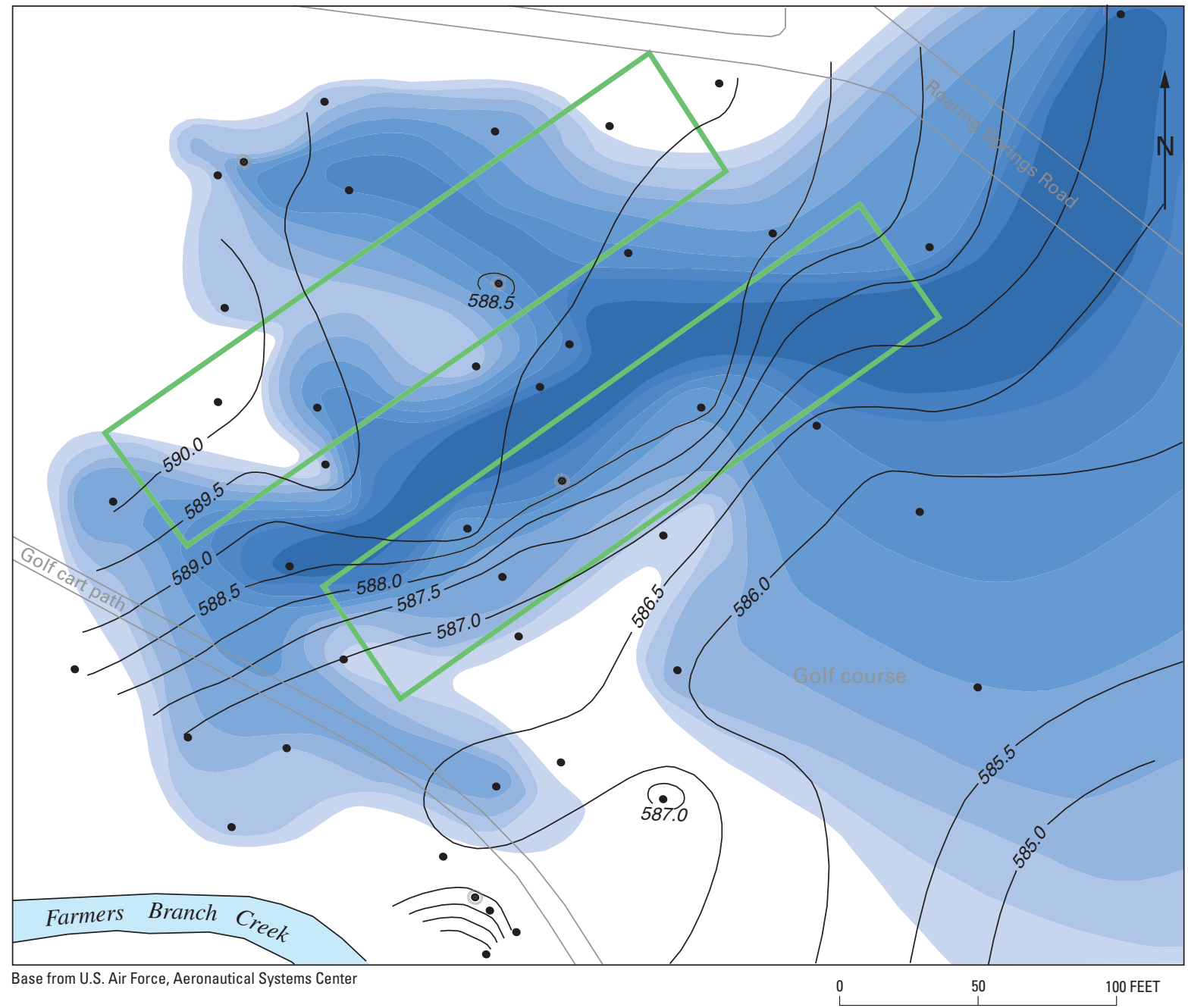

\section{EXPLANATION}

Estimated drawdown, in inches

Less than 3.0

3.0 to 3.9

4.0 to 4.9

5.0 to 5.9

6.0 to 6.9

7.0 to 7.9

8.0 to 8.9

9.0 to 9.9

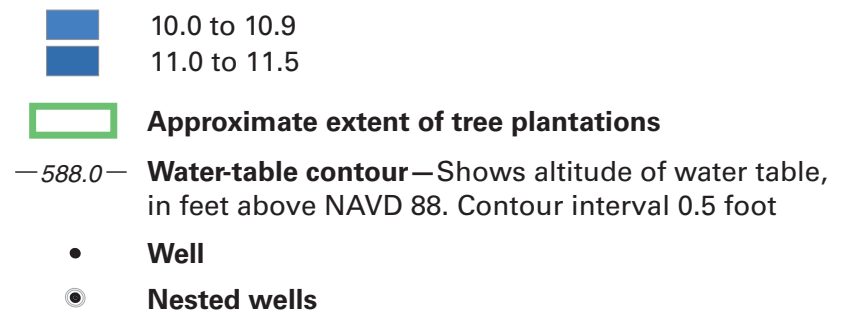

Figure 8. Estimated drawdown attributed to planted trees, September 19-20, 2000.

had a mean height of $18 \mathrm{ft}$, and the calipers had a mean height of $21.7 \mathrm{ft}$ in 1998.

During the fifth growing season (2000) the trees showed signs of severe water stress in areas where ground-water depth was greater than $11.5 \mathrm{ft}$ below land surface. The fifth growing season was characterized by drought conditions (fig. 6) that might have amplified the influence of variations in soil structure at the site (Hamblin, 1985), differences in root biomass that might have resulted from planting strategy variations, and differences in drought tolerance of the different cottonwood vari- eties that were planted (Tschaplinski and others, 1998; Khurana and others, 2000). Because the trees had been irrigated during the first 2 years of the study, differences in ability to access ground water between whips and calipers might have been masked (Persson, 1995).

In January 2003, the diameters of trees in both plantations were measured and compared to ground-water depths from September 2000, when the site was in the midst of a drought. These data are shown in figure 4 (whips) and figure 5 (calipers); 
the figures also indicate which trees were stunted by beaver activity and which trees died.

In the whip plantation, mortality was relatively constant between about 25 and 30 percent where ground-water depth was less than $10 \mathrm{ft}$ (fig. 4). Mortality increased substantially where ground-water depth exceeded $10 \mathrm{ft}$, and approached 90 percent for ground-water depths between 12 and $13 \mathrm{ft}$. This is consistent with findings of Stone and Kalisz (1991), who reported a maximum rooting depth for eastern cottonwood trees of about $11.8 \mathrm{ft}$. Mean tree diameter also increased as groundwater depth increased; however, this relation did not hold true when the sample size within a depth interval was small (less than 20 trees), as was the case for depth intervals from 6 to $7 \mathrm{ft}$, 12 to $13 \mathrm{ft}$, and 13 to $14 \mathrm{ft}$. During periods of drought, larger, more deeply rooted trees were more likely to survive than smaller neighboring trees. As smaller neighboring trees died, this allowed for more growth of the remaining trees because of less competition for water, nutrients, and space.

Almost one-half ( 49 percent) of the trees in the caliper plantation were either stunted by beaver activity ( 40 percent) or altered by human activities ( 9 percent). These trees could not be included in computations related to tree diameter and made mortality-based computations problematic. As a result, plots of ground-water depth and mean tree diameter and ground-water depth and percent mortality were not included in figure 5 . In the caliper plantation, the mean diameter of trees was about 6.75 in. in January 2003 in areas where September 2000 ground-water depths were greater than $9 \mathrm{ft}$, whereas the mean diameter was about 8.25 in. in the remainder of the plantation, where groundwater depths were less than $9 \mathrm{ft}$. These computations do not include trees that were stunted by beaver activity.

\section{Effects of Water-Level Variations on Ground-Water Biogeochemistry}

Results from water-quality sampling provide insight into the oxidation-reduction processes occurring in the aquifer and effects of water-level variations. The molar ratio of TCE to cisDCE (TCE/cis-DCE) can be used to evaluate degradation of TCE to $c i s$-DCE. Decreases in the molar ratio of TCE/cis-DCE were observed in samples collected from most wells within and downgradient from the planted area over time. Observed decreases in TCE/cis-DCE appear to be related to ground-water depth. Eberts and others (2003) observed the lowest TCE/cisDCE at the end of the fifth growing season (September 2000) in samples collected from wells where ground-water depth was less than $10 \mathrm{ft}$. They also observed that September $2000 \mathrm{sam}$ ples from wells with the lowest TCE/cis-DCE (wells 511, 514, and 515) had the lowest DO concentrations, 0.93 to $1.7 \mathrm{mg} / \mathrm{L}$, and the highest DOC concentrations, 1.6 to $1.8 \mathrm{mg} / \mathrm{L}$. Mean DO and DOC concentrations for the rest of the September 2000 samples were 3.9 and $1.1 \mathrm{mg} / \mathrm{L}$, respectively. In contrast, $\mathrm{TCE} /$ cis-DCE values during the third growing season (June 1998) were relatively constant, between 3.0 and 4.0, across the site except near well 514 and at the wells adjacent to the 19-year old cottonwood (fig. 9; fig. 3 for location of cottonwood). This indicates that between the third and fifth growing seasons, DOC had been introduced into the aquifer by the planted trees, which had stimulated reductive dechlorination of TCE. This conclusion is consistent with observations made by Schiff and others (1997) who reported that DOC in ground water, which came largely from roots and leaching of leaf litter, generally is not active in the geochemical system except where ground water is shallow enough to interact with recently generated DOC before it is consumed by microbes. TCE/cis-DCE, DO, and DOC results are in appendix tables A-4-A-6.

The relation between ground-water depth and TCE/cisDCE also can be used to explain the increase in mean TCE/cisDCE beneath and downgradient from the planted area between January and July 2001. The water table was almost $2 \mathrm{ft}$ higher in January than it was in July 2001; therefore, the ground-water depth was almost $2 \mathrm{ft}$ greater in July 2001 (figs. 10 and 11). This was the greatest measured decline in the water table between two sampling events during the study. As a result, shallow ground water had greater contact with the microbially active root zone in January than in July, and less degradation of TCE occurred in July than in January. Microbial communities also might have been stressed during July because of changes in water levels. Because the labile component of DOC is partially derived from leaching of leaf litter, it is also possible that TCE/cis-DCE values in January were influenced by an increased availability of DOC introduced by infiltrating precipitation.

DO data collected during September 2000, January 2001, July 2001, January 2002, and July 2002 were grouped into different ground-water-depth intervals and graphed (fig. 12a). The boxplots generally show a gradual increase in median DO concentrations as ground-water depth increases. This general trend also can be seen in figure 12b, which shows TCE/cis-DCE for ground-water-depth intervals for the same dates. In the molar ratio graph, there is a pronounced increase in median TCE/ cis-DCE at a ground-water depth of about $6.5 \mathrm{ft}$, which indicates less degradation of TCE occurs. The dates that were used to generate the boxplots were selected because they were the only dates that had a consistent method of chemical analysis in addition to corresponding ground-water-depth data.

Data collected from well 516 demonstrates the relation between the trees, ground-water depth, and ground-water biogeochemistry (fig. 13). In July 2000, the DO concentration was less than $1.0 \mathrm{mg} / \mathrm{L}$, and the TCE/cis-DCE also was less than 1.0 in samples from well 516. Both of these low values indicate that in-place biodegradation was occurring. After July 2000, a drought occurred in the area that greatly stressed trees around well 516. As trees around well 516 began to die, both the DO concentration and the TCE/cis-DCE gradually increased to values greater than those previously observed. 


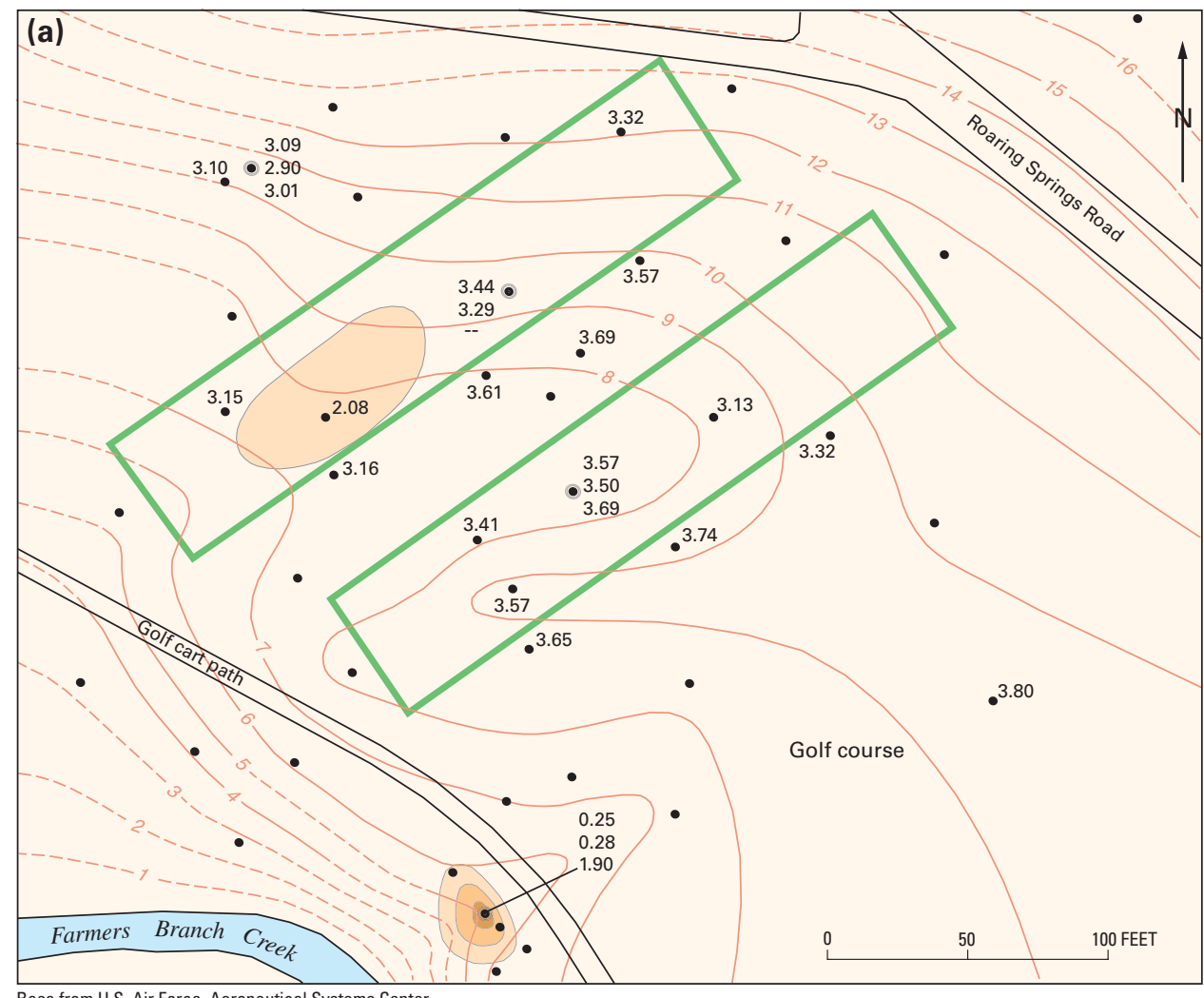

EXPLANATION

Molar ratio of TCE to cis-DCE

Less than 1.01

1.01 to 2.00

2.01 to 3.00

3.01 to 4.00

Approximate extent of tree plantations

-5- Line of equal ground-water depth, in feet below land surface-Interval 1 foot; dashed where inferred

- Well-Number is molar

3.32 ratio of TCE to cis-DCE

- Nested wells-Number is

3.09 molar ratio of TCE to cis-DCE;

$2.90--$, not sampled

- Well-No data for sampling event; interpretation (shade pattern) based on pre- and post-June 22, 1998 sampling

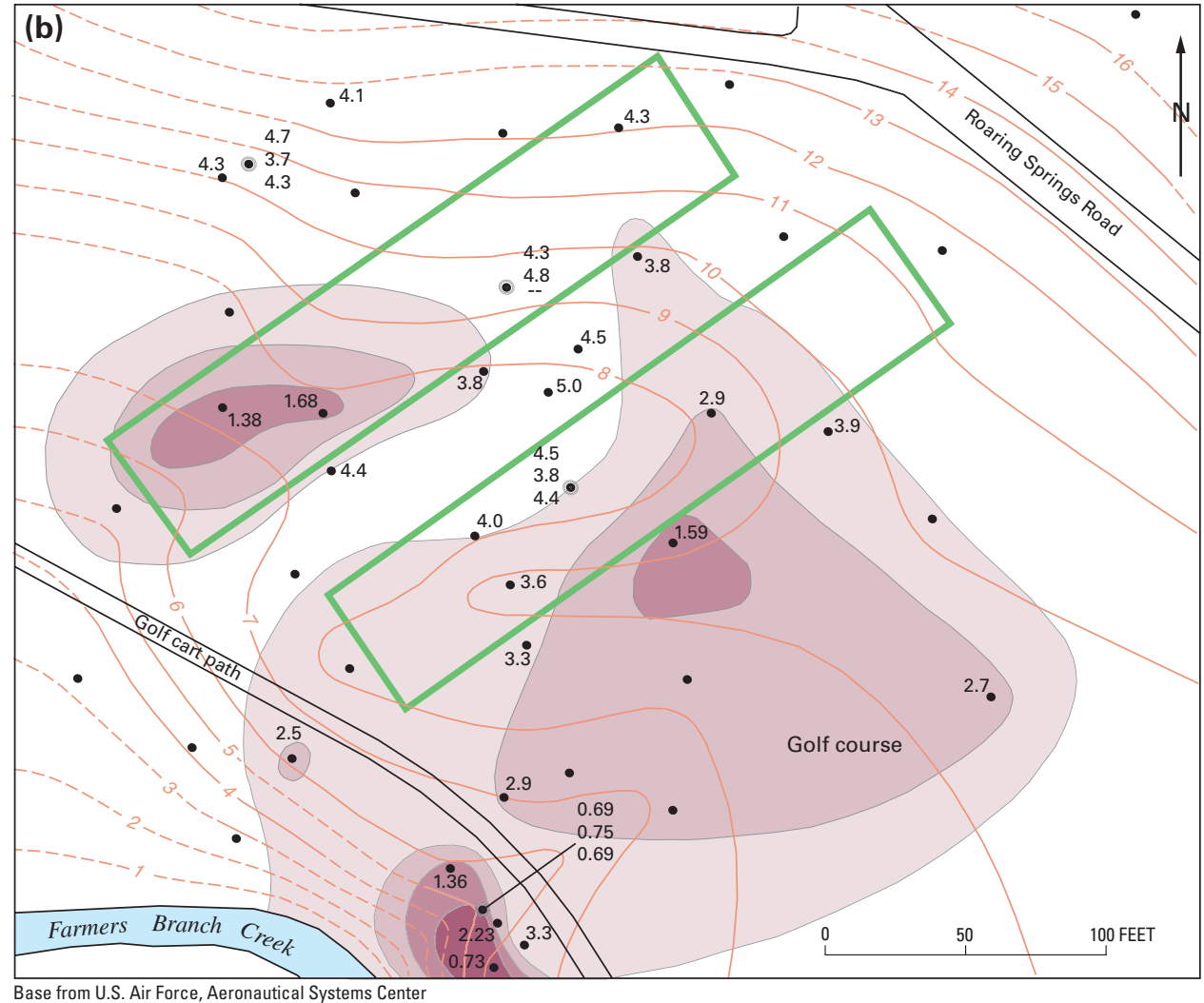

EXPLANATION

Dissolved oxygen concentration, in milligams per liter

Less than 1.01

1.01 to 2.00

2.01 to 3.00

3.01 to 4.00

Greater than 4.0

Approximate extent of tree plantations

Line of equal ground-water depth, in feet below land surface-Interval 1 foot; dashed where inferred

- Well-Number is dissolved 3 oxygen concentration, in milligrams per liter

- Nested wells-Number is

4.7 dissolved oxygen concen-

3.7 tration, in milligrams per

4.3 liter; --, not sampled

- Well-No data for sampling event; interpretation (shade pattern) based on pre- and post-June 22, 1998 sampling

Figure 9. Lines of equal ground-water depths and (a) molar ratio of trichloroethene (TCE) to cis-dichloroethene (cis-DCE), and (b) dissolved oxygen concentrations, June 22, 1998. 


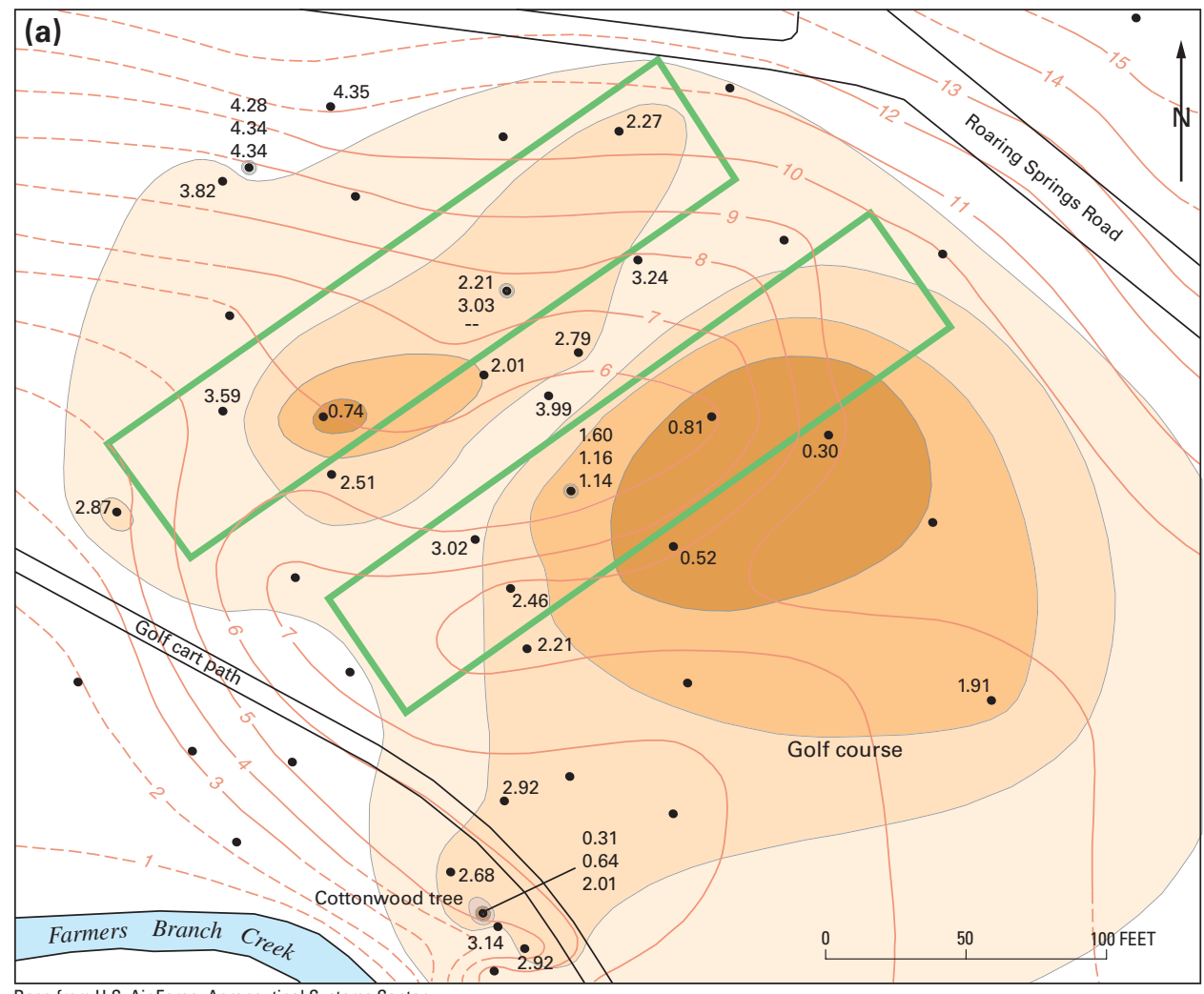

\section{EXPLANATION}

Molar ratio of TCE to cis-DCE

Less than 1.01

1.01 to 2.00

2.01 to 3.00

3.01 to 4.00

Greater than 4.0

Approximate extent of tree plantations

-5- Line of equal ground-water depth, in feet below land surface-Interval 1 foot dashed where inferred

- Well-Number is mola

2.27 ratio of TCE to cis-DCE

- Nested wells-Number is

4.28 molar ratio of TCE to cis-DCE;

4.34 --, not sampled

4.34

Well-No data for sampling event; interpretation (shade pattern) based on pre- and post-January 8, 2001 sampling

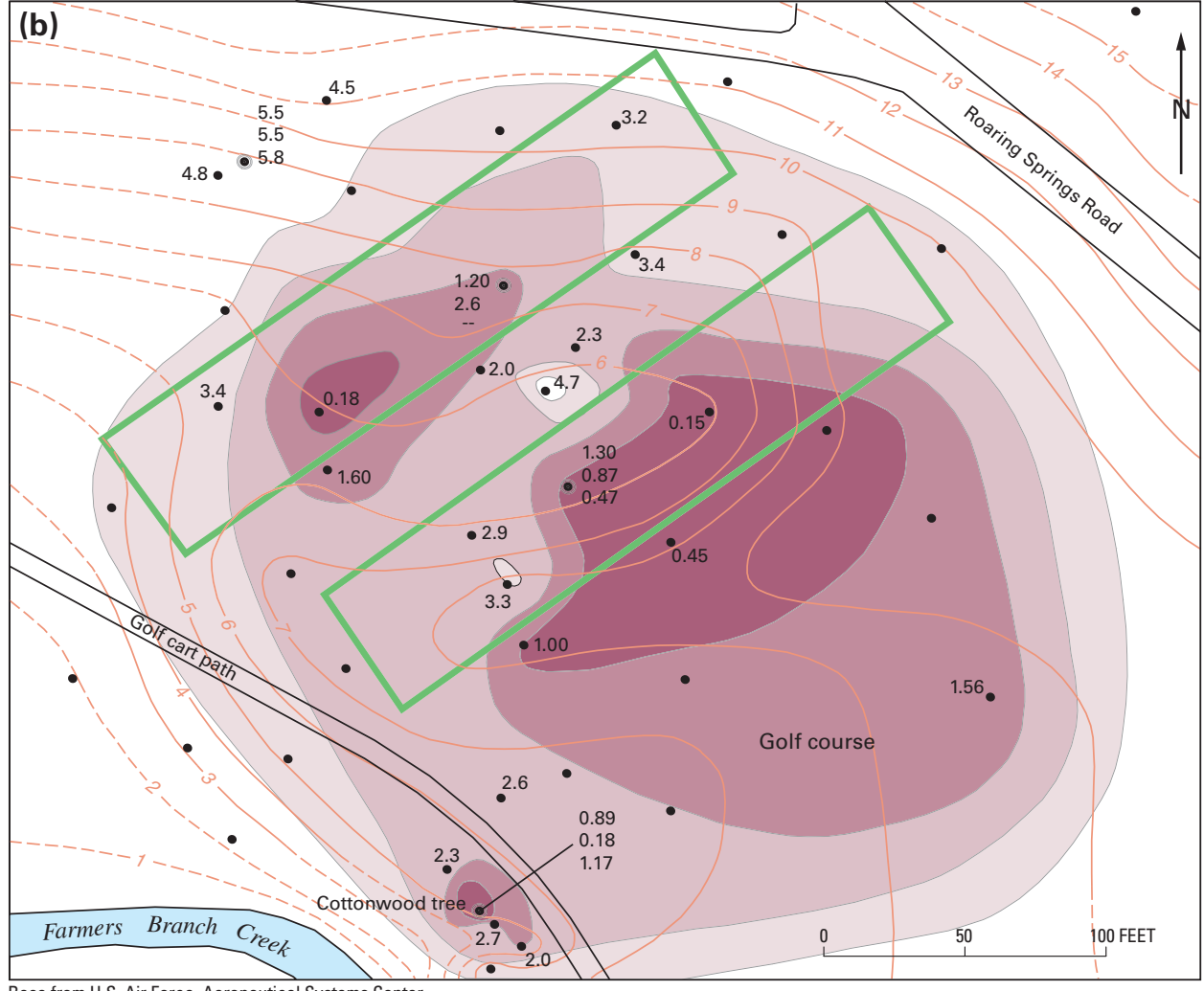

\section{EXPLANATION}

Dissolved oxygen concentration, in milligams per liter

Less than 1.01

1.01 to 2.00

2.01 to 3.00

3.01 to 4.00

Greater than 4.0

Approximate extent of tree plantations

-5- Line of equal ground-wate depth, in feet below land surface-Interval 1 foot dashed where inferred

- Well-Number is dissolved oxygen concentration, in milligrams per liter

- Nested wells-Number is 5.5 dissolved oxygen concen5.5 tration, in milligrams per

5.8 liter; --, not sampled

- Well-No data for sampling event; interpretation (shade pattern) based on pre- and post-January 8, 2001 sampling

Figure 10. Lines of equal ground-water depths and (a) molar ratio of trichloroethene (TCE) to cis-dichloroethene (cis-DCE), and (b) dissolved oxygen concentrations, January 8, 2001. 


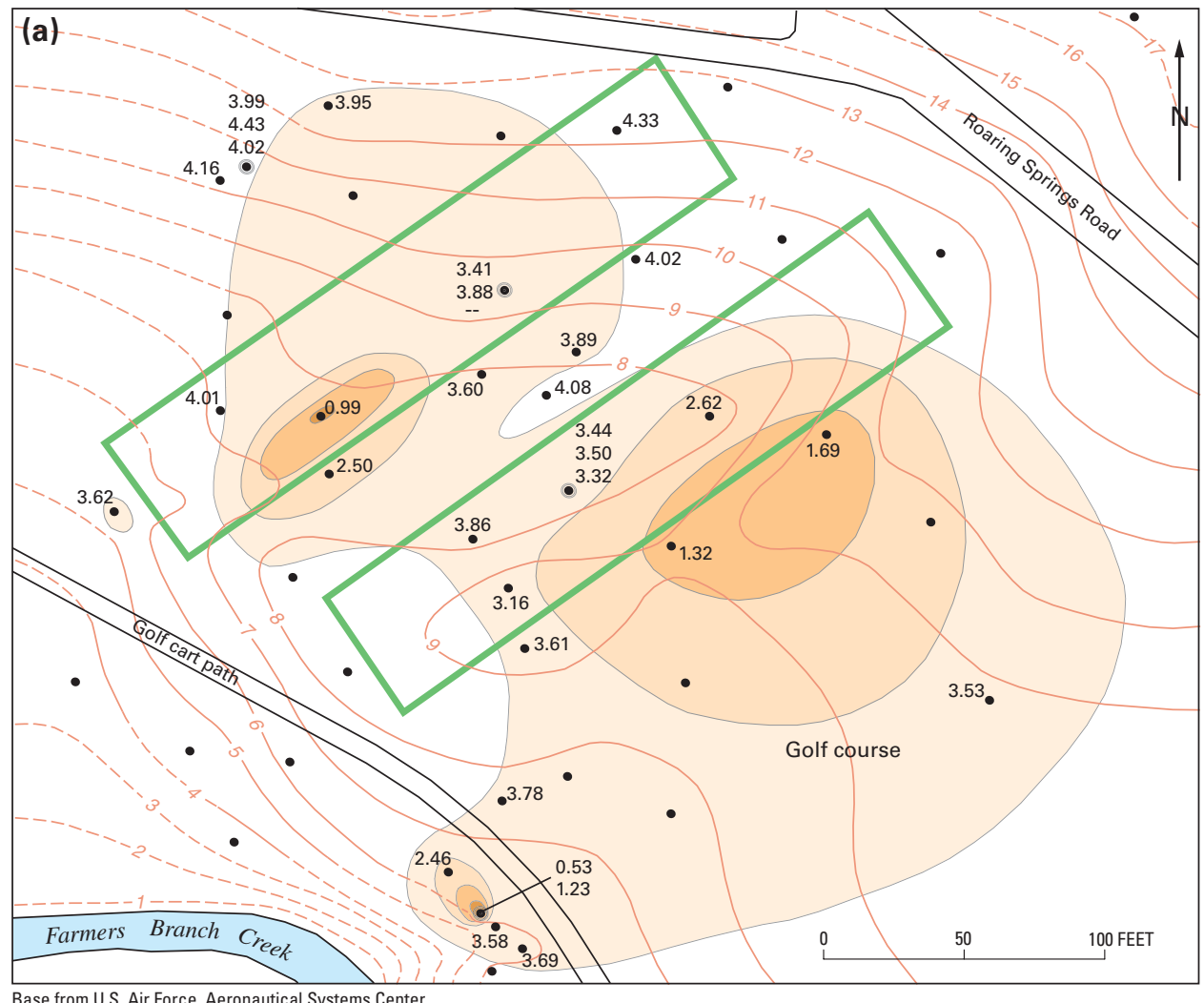

\section{EXPLANATION}

Molar ratio of TCE to cis-DCE

Less than 1.01

1.01 to 2.00

2.01 to 3.00

3.01 to 4.00

Greater than 4.0

Approximate extent of tree plantations

-5- Line of equal ground-water depth, in feet below land surface-Interval 1 foot dashed where inferred

- Well-Number is molar

4.02 ratio of TCE to cis-DCE

- Nested wells-Number is 3.99 molar ratio of TCE to cis-DCE:

4.43 --, not sampled

4.02

- Well-No data for sampling event; interpretation (shade pattern) based on pre- and post-July 12-13, 2001 sampling

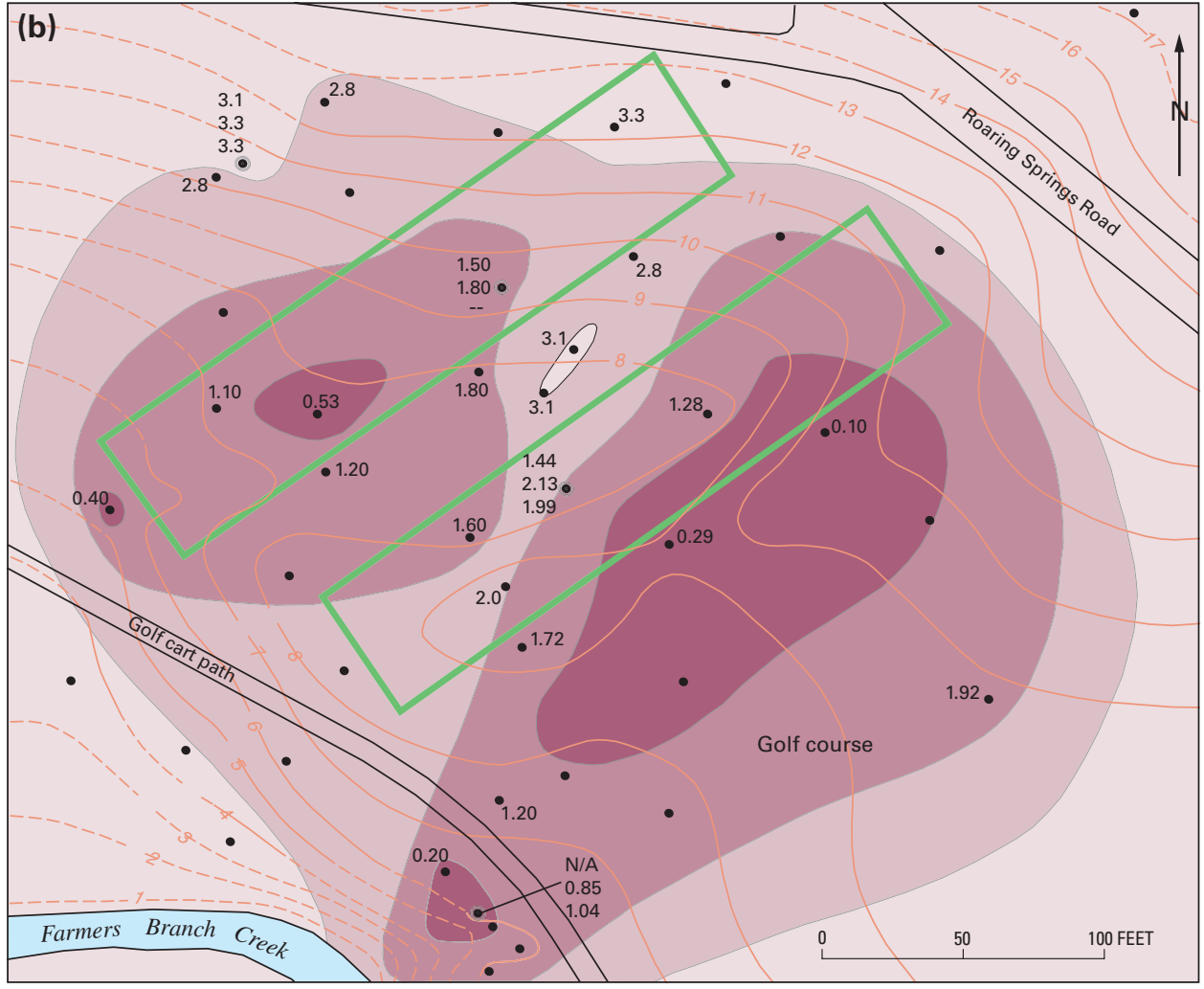

\section{EXPLANATION}

Dissolved oxygen concentration, in milligams per liter

Less than 1.01

1.01 to 2.00

2.01 to 3.00

3.01 to 4.00

Approximate extent of tree plantations

Line of equal ground-water depth, in feet below land surface-Interval 1 foot; dashed where inferred

- Well-Number is dissolved oxygen concentration, in milligrams per liter

- Nested wells-Number is 3.1 dissolved oxygen concen3.3 tration, in milligrams per

3.3 liter; --, not sampled

- Well-No data for sampling event; interpretation (shade pattern) based on pre- and post-July 12-13, 2001 sampling

Base from U.S. Air Force, Aeronautical Systems Center

Figure 11. Lines of equal ground-water depths and (a) molar ratio of trichloroethene (TCE) to cis-dichloroethene (cis-DCE), and (b) dissolved oxygen concentrations, July 12-13, 2001. 

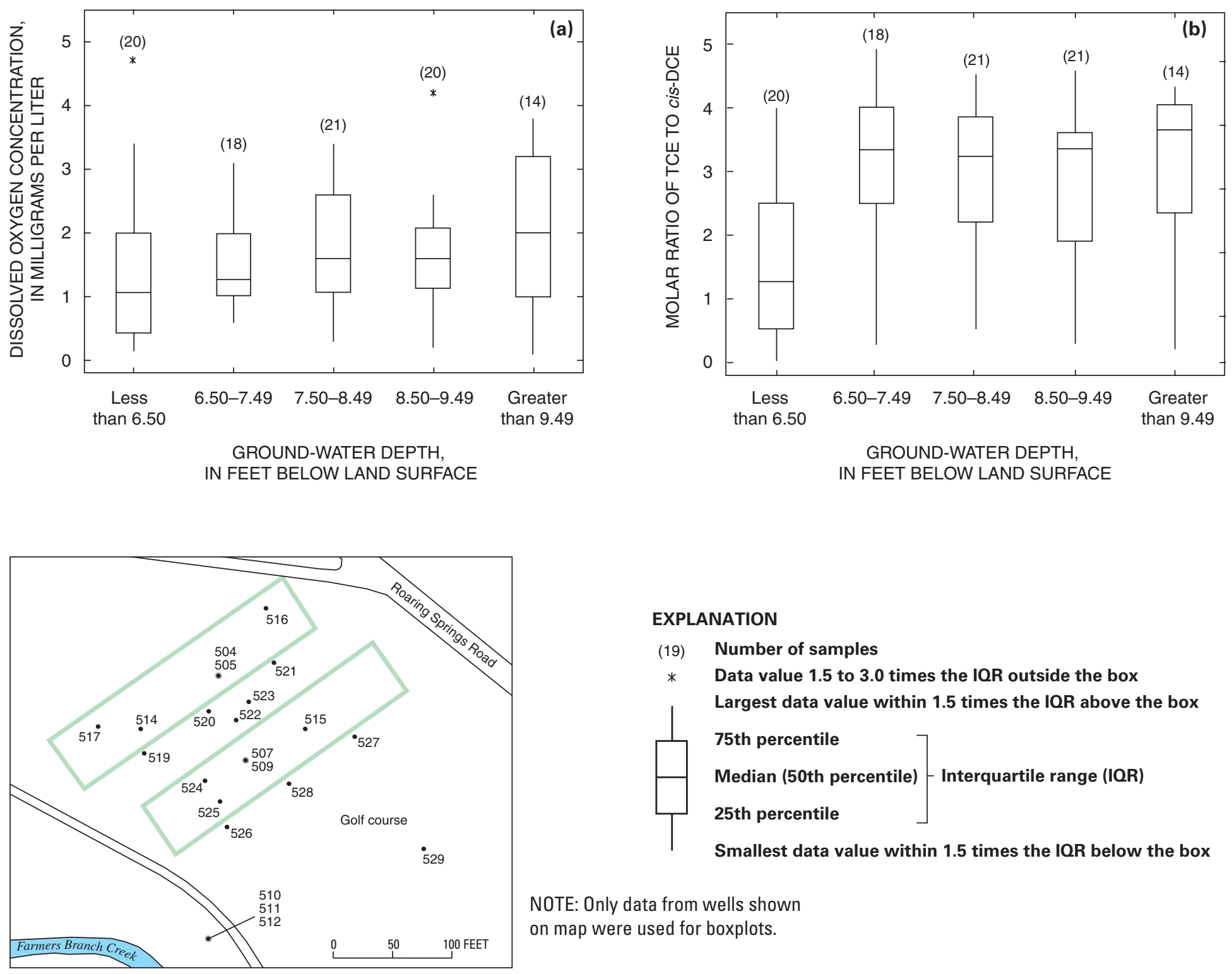

\section{EXPLANATION}

(19) Number of samples

* Data value 1.5 to 3.0 times the IQR outside the box

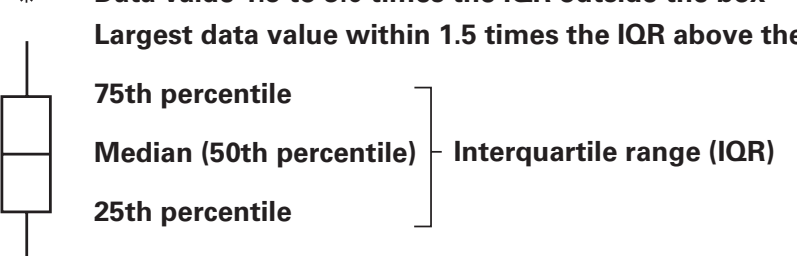

Smallest data value within 1.5 times the IQR below the box

NOTE: Only data from wells shown on map were used for boxplots.

Figure 12. Boxplots showing distribution of (a) dissolved oxygen concentrations, September 2000-July 2002, and (b) molar ratios of trichloroethene (TCE) to cis-dichloroethene (cis-DCE), September 2000-July 2002 for selected ground-water depths. 


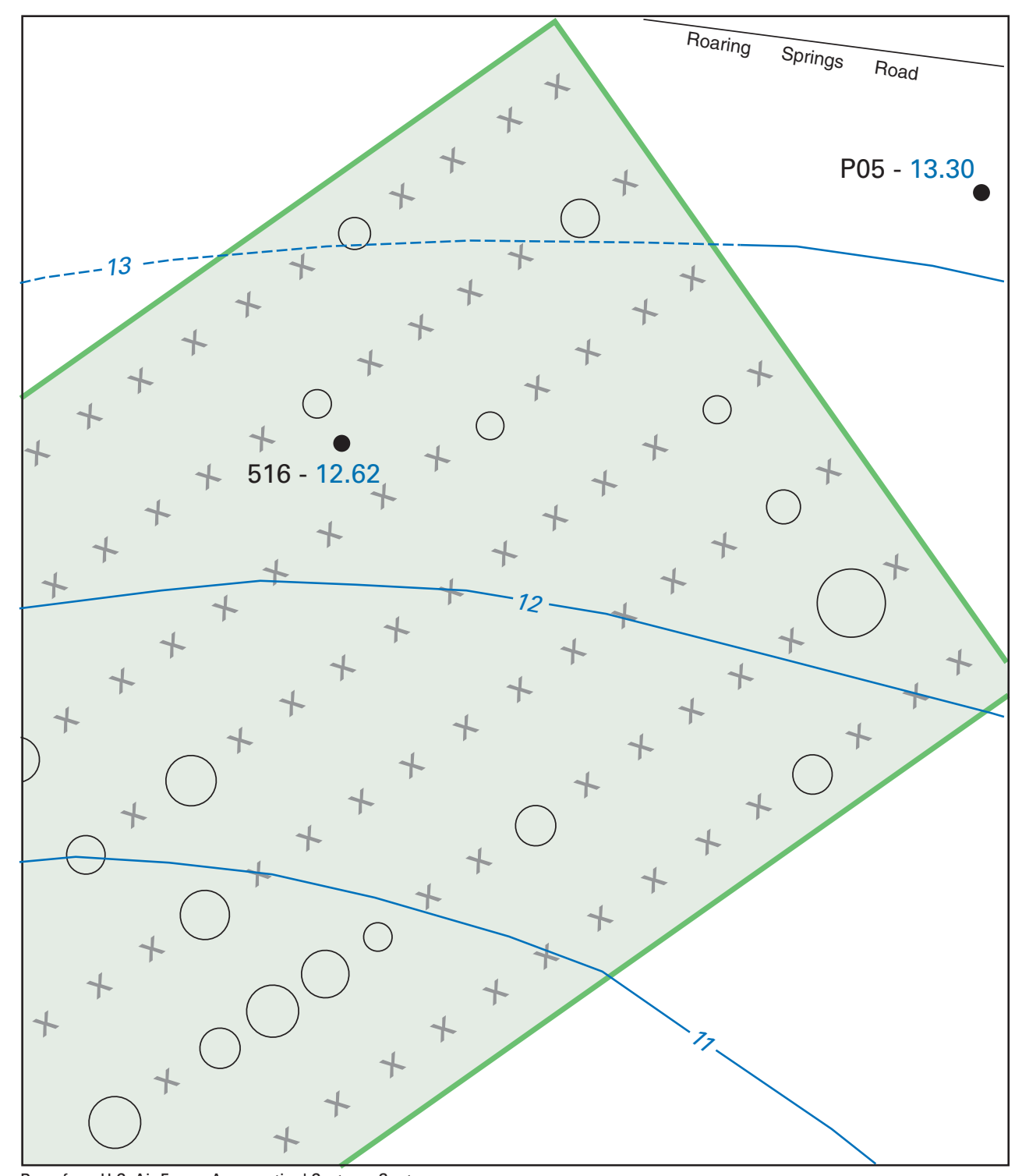

Base from U.S. Air Force, Aeronautical Systems Center

25

50 FEET
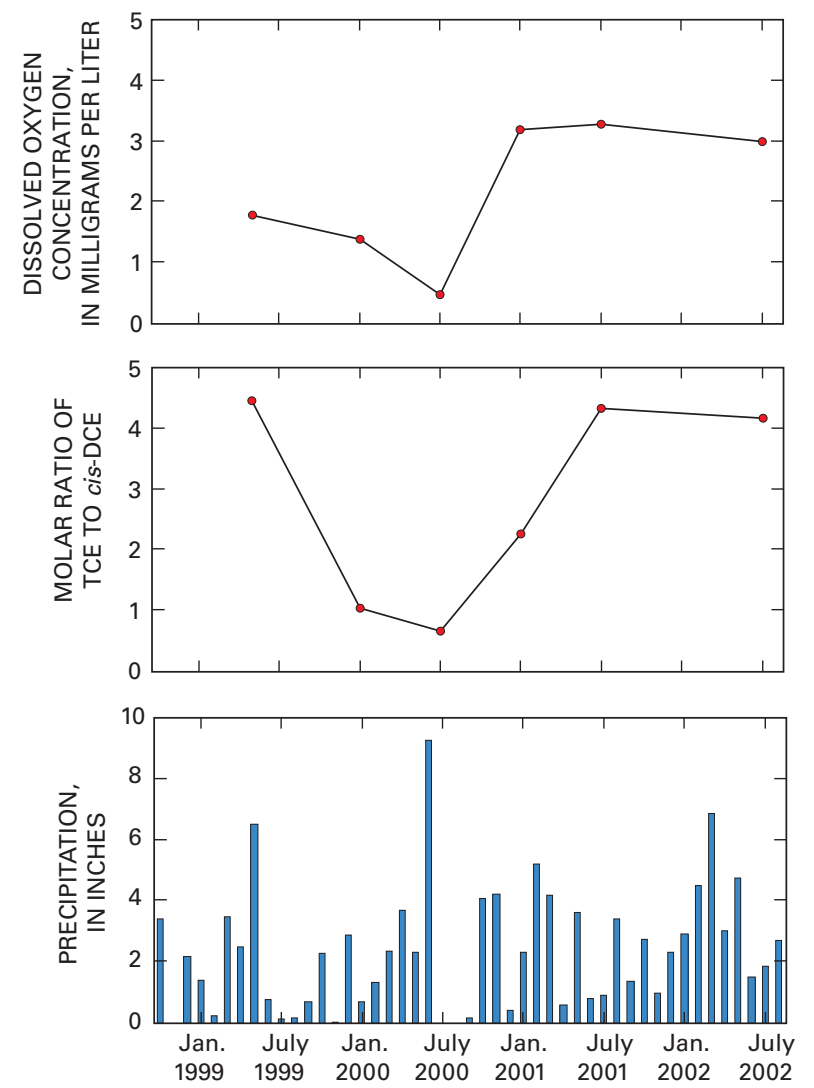

EXPLANATION

Approximate extent of tree plantations

-11- Line of equal ground-water depth in feet below

land surface-Measured Sept. 19-20, 2000. Interval

1 foot; dashed where inferred

$\bigcirc \quad$ Represents location and relative diameter of tree

\section{$X \quad$ Represents location of dead tree}

- Well-Numbers indicate well number and ground-

516 - water depth, in feet below land surface (September 12.62 2000)

Figure 13. Location and relative diameter of remaining trees within the whip plantation near well 516, graphs of dissolved oxygen concentration and molar ratio of trichloroethene (TCE) to cis-dichloroethene (cis-DCE) from well 516 samples for selected sampling events, and graph of monthly precipitation from the nearby Naval Air StationJoint Reserve Base Carswell Field. 


\section{Summary}

In 1996, a field-scale phytoremediation demonstration project was initiated by the U.S. Air Force at a site in western Fort Worth, Tex., near Air Force Plant 4. The primary objective of this project was to determine the effectiveness of eastern cottonwoods at reducing the mass of dissolved trichloroethene (TCE) that is being transported within an alluvial aquifer. Eastern cottonwoods have the potential to add organic carbon to ground water, which facilitates in-place microbial degradation of TCE and also might remove contaminants from ground water.

The demonstration project was initiated using a plantation of 1-year-old stems harvested from branches of eastern cottonwoods during the dormant season (whips) and a plantation of 1-year-old eastern cottonwood seedlings (calipers). The U.S. Geological Survey, in cooperation with the U.S. Air Force, collected water-level and water-quality data throughout the duration of the demonstration project. This study was conducted to determine water-level variations at the phytoremediation demonstration site and to determine the effects of the water-level variations on tree growth and mortality and on the biogeochemical system.

This report presents spatial changes in water-level altitudes and ground-water depths at periodic sampling events; data from August 1996 to January 2003 are presented in this report. This report also describes factors affecting water-level variations, such as aquifer properties, precipitation, irrigation, and drawdown attributable to the trees. This report also evaluates the effects of ground-water depth on tree growth, mortality rates, and subsurface oxidation-reduction processes.

Water levels in the study area can be influenced by shortterm stresses such as precipitation because the alluvial aquifer is thin, unconfined, and very permeable. A strong relation between precipitation and ground-water levels exists. Transpiration effects of the trees also influence water levels through induced drawdown. During the peak of the third growing season (June 1998), the maximum drawdown that could be attributed to trees was 4.0 to 4.9 in. However, by the end of the fifth growing season (September 2000), the maximum observed drawdown was about 11.5 in. A drip irrigation system was required to supplement precipitation during the first two growing seasons (1996-97). Roots were expected to intercept most or all percolating irrigation water; therefore, irrigation was not considered to be an additional source of water to the aquifer.

Rates of tree growth were documented to gage the effectiveness of the phytoremediation system over time. Overall, whips and calipers showed a substantial increase in height, canopy diameter, and trunk diameter during the first 3 years of the study. By the fifth growing season (September 2000), the heights of calipers varied predictably with ground-water depth; the trees showed signs of severe stress in areas where groundwater depth was more than $11.5 \mathrm{ft}$ below land surface. In January 2003, the diameter of each tree was measured and compared to ground-water depths from September 2000, when the site was in the midst of a drought. Mortality was relatively constant between about 25 and 30 percent in the whip plantation where ground-water depth was less than $10 \mathrm{ft}$. Mortality increased substantially as ground-water depth exceeded $10 \mathrm{ft}$ and approached 90 percent for ground-water depths between 12 and $13 \mathrm{ft}$.

TCE/cis-dichloroethene (cis-DCE) decreased during the study period in samples from most of the wells within and downgradient from the planted area over time. Observed decreases in TCE/cis-DCE appear to be related to ground-water depth. TCE/cis-DCE during the third growing season (June 1998) was relatively constant, between 3.0 and 4.0, across the site with a few exceptions. By the end of the fifth growing season (September 2000), the lowest TCE/cis-DCE values were observed in samples from wells where ground-water depths were less than $10 \mathrm{ft}$; these samples contained the lowest dissolved oxygen concentrations, 0.93 to $1.7 \mathrm{mg} / \mathrm{L}$, and the highest dissolved organic carbon concentrations, 1.6 to $1.8 \mathrm{mg} / \mathrm{L}$. Between the third and fifth growing seasons, a labile fraction of dissolved organic carbon was introduced into the aquifer by the planted trees that was capable of stimulating reductive dechlorination of TCE.

\section{References Cited}

Eberts, S.M., Harvey, G.J., Jones, S.A., and Beckman, S.W., 2003, Multiple process assessment for a chlorinated-solvent plume, in McCucheon, S.C., and Schnoor, J.L., eds., Phytoremediation-Transformation and control of contaminants: Hoboken, N.J., Wiley, p. 589-633.

Gilbert, T.W., Behymer, T.D., and Castaneda, H.B., 1982, Determination of dissolved oxygen in natural and waste waters: American Laboratory, American Society for Testing and Materials ASTM D 888-87, p. 119-134.

Hamblin, A.P., 1985, The influence of soil structure on water movement, crop root growth, and water uptake: Advances in Agronomy, v. 38, p. 95-157.

Hansen, E.A., 1993, Soil carbon sequestration beneath hybrid poplar plantations in the north central United States: Biomass and Bioenergy, v. 5, no. 6, p. 431-436.

Haycock, N.E., and Pinay, G., 1993, Groundwater nitrate dynamics in grass and poplar vegetated riparian buffer strips during winter: Journal of Environmental Quality, v. 22, p. 273-278.

Jacobs Engineering Group Inc., 1996, Technology demonstration plan treatability study for plant-enhanced bioremediation of contaminated soil and groundwater-Draft final: Fort Worth, Tex., U.S. Air Force Aeronautical Systems Center, Air Force Plant 4 [variously paged].

Khurana, D.K., Narljede, S., and Chandrashekhar, M.B., 2000, Rooting behavior-An indicator of plantation success and growth in poplars in Populus production systems, in Isebrands, J.G., and Richardson, J., eds., 21st Session of the International Poplar Commission, Poplar and willow culture-Meeting the needs of society and the environment, 
Vancouver, Wash., September 24-28, 2000: St. Paul, Minn., U.S. Department of Agriculture, Forest Service, North Central Research Station, General Technical Report NC-125, p. 93.

Krinard, R.M., 1985, Cottonwood development through 19 years in a Nelder's Design: U.S. Department of Agriculture, Forest Service, Southern Forest Experiment Station, Research Note SO-322, 4 p.

Kuniansky, E.L., Jones, S.A., Brock, R.D., and Williams, M.D., 1996, Hydrogeology at Air Force Plant 4 and vicinity and water quality of the Paluxy aquifer: U.S. Geological Survey Water-Resources Investigation Report 96-4091, 41 p.

Leigh, M.B., Fletcher, J.S., Xiong, Fu, and Schmitz, F.J., 2002, Root turnover-An important source of microbial substrates in rhizosphere remediation recalcitrant contaminants: Environmental Science and Technology, v. 36, p. 1,579-1,583.

Licht, L.A., and Madison, Mark, 1994, Phytoremediation of groundwater at Air Force Plant 4, Carswell. Texas-Innovative technology evaluation report: Proceedings of the 87th meeting of the Air and Waste Management Association, June 19-24, 1994, Cincinnati, Ohio.

McCutcheon, S.C., and Schnoor, J.L., 2003, Overview of phytotransformation and control of wastes, in McCucheon, S.C., and Schnoor, J.L., eds., Phytoremediation-Transformation and control of contaminants: Hoboken, N.J., Wiley, p. 3-58.

National Climatic Data Center, 2002, Daily climatic data: U.S. Department of Commerce, National Oceanic and Atmospheric Administration, accessed December 16, 2002 , at URL

http://www4.ncdc.noaa.gov/cgi-win/ wwcgi.dll?wwDI StnSrch StnID 10011153

Perlack, R.D., Wright, L.L., Huston, M.A., and Schramm, W.E., 1995, Biomass fuel from woody crops for electric power generation: Oak Ridge, Tenn., Oak Ridge National Laboratory.

Persson, G., 1995, Willow stand evapotranspiration simulated for Swedish soils: Agricultural Water Management, v. 28, p. 271-293.

RUST Geotech, 1996, Interim Air Force Plant 4 assessment of intrinsic bioremediation: Prepared for U.S. Air Force, Headquarters Aeronautical Systems Center, Wright Patterson Air Force Base, Ohio, contract no. DE-AC04-94AL96907 [variously paged].

Schiff, S.L., Aravena, R., Trumbore, S.E., Hinton, M.J., Elgood, R., and Dillon, P.J., 1997, Export of DOC from forested catchments on the Precambrian Shield of central Ontario-Clues from ${ }^{13} \mathrm{C}$ and ${ }^{14} \mathrm{C}$ : Biogeochemistry, v. 36, p. $43-65$.

Stone, E.L., and Kalisz, P.J., 1991, The maximum extent of tree roots: Forest Ecology and Management, v. 46, p. 77.

Tschaplinski, T.J., Tuskan, G.A., Gebre, G.M., and Todd, D.E., 1998, Drought resistance of two hybrid Populus clones grown in a large-scale plantation: Tree Physiology, v. 18, p. 653-658.

U.S. Air Force, Air Force Center for Environmental Excellence, 1997, Technical report for the ERPIMS 2.0 database model of the Environmental Resources Program Information Management System: San Antonio, Tex., U.S. Air Force, Brooks Air Force Base, 112 p.

Wiedemeier, T.H., Swanson, M.A., Moutox, D.E., Gordon, E.K., Wilson, J.T., Wilson, B.H., Kampbell, D.H., Haas, P.E., Miller, R.N., Hansen, J.E., and Chapelle, F.H., 1996, Technical protocol for evaluating natural attenuation of chlorinated solvents in ground water-Draft revision 1: San Antonio, Tex., Air Force Center for Environmental Excellence Technology Transfer Division, Brooks Air Force Base [variously paged]. 
Appendix

$\longrightarrow$ 


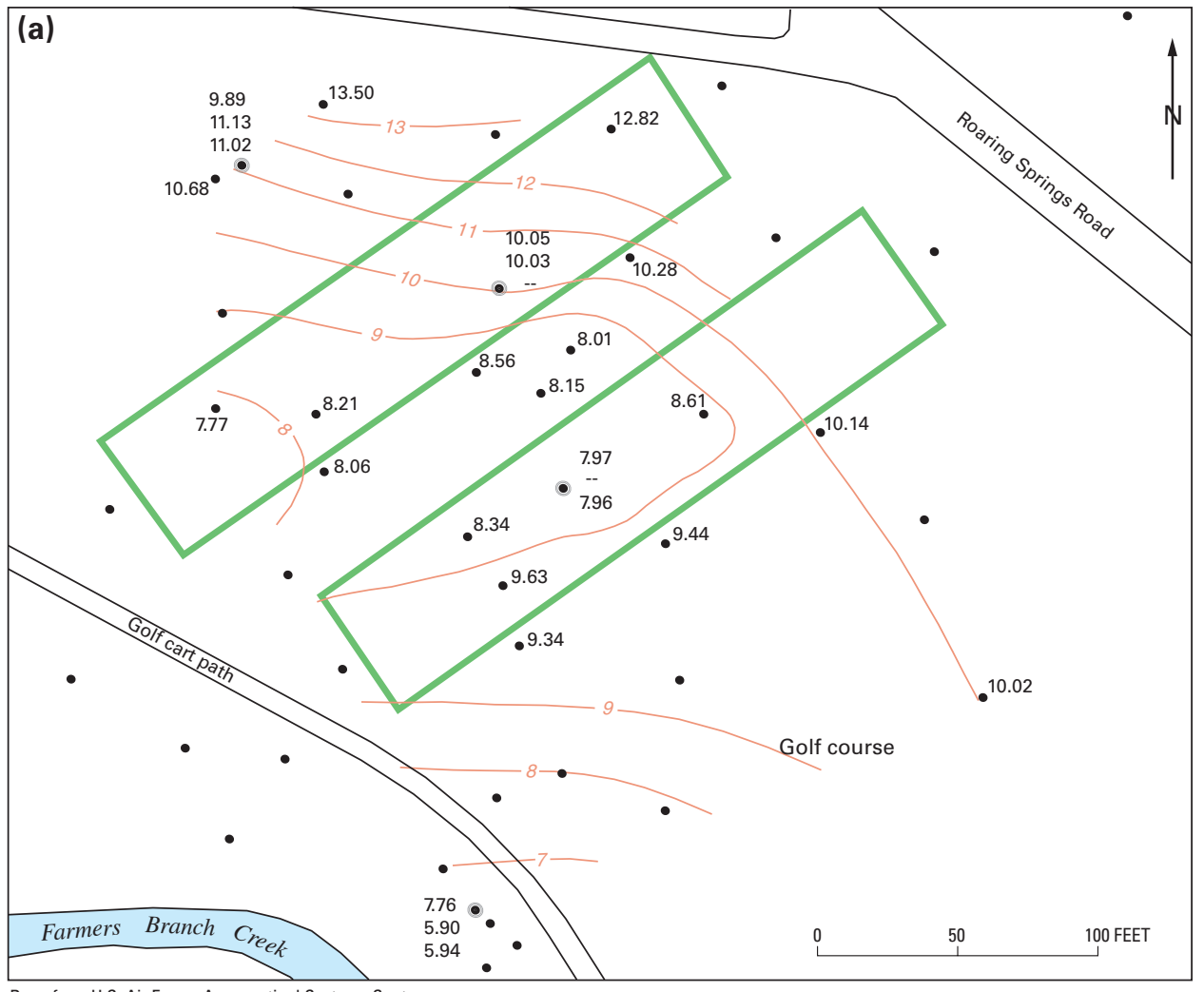

EXPLANATION

Approximate extent of tree plantations

-7 - Line of equal ground-water depth, in feet below land surface-Interval 1 foot

- Well-Number is ground-water depth, in feet below land surface

- Nested wells-Numbers are

3.09 ground-water depths, in feet

2.90 below land surface; --, not

3.01 available

- Well-No data for sampling event

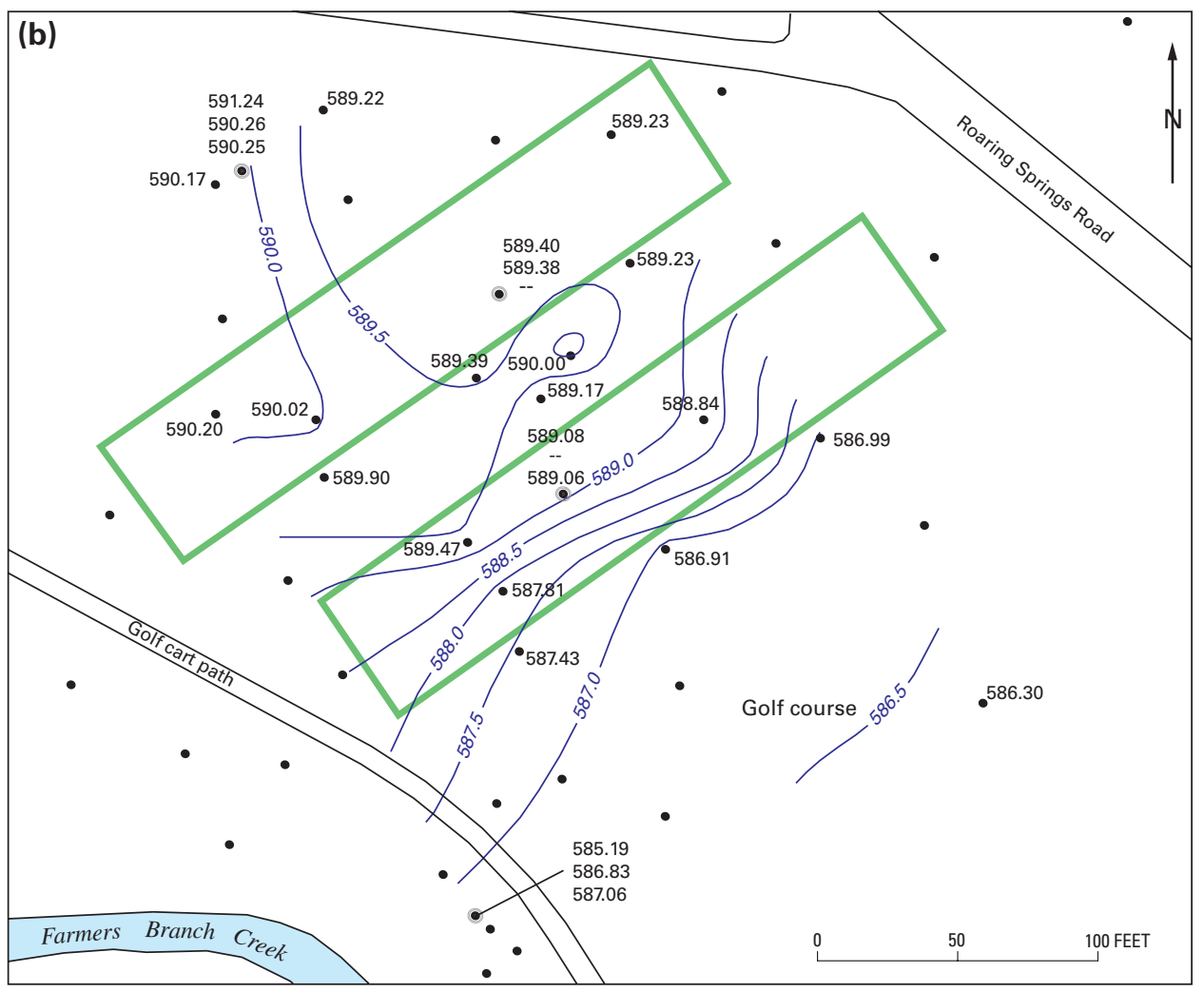

EXPLANATION

Approximate extent of tree plantations

-590.0-Water-table contour-Shows altitude of water table, in feet above NAVD 88. Contour interval 0.5 foot

- Well-Number is altitude of water level, in feet above NAVD 88

- Nested wells-Numbers are 85.19 altitudes of water levels, in 586.83 feet above NAVD 88; --, not 587.06 available

- Well-No data for sampling event

Figure A-1. (a) Lines of equal ground-water depths and (b) water-level altitude contours for Aug. 17-22, 1996. 


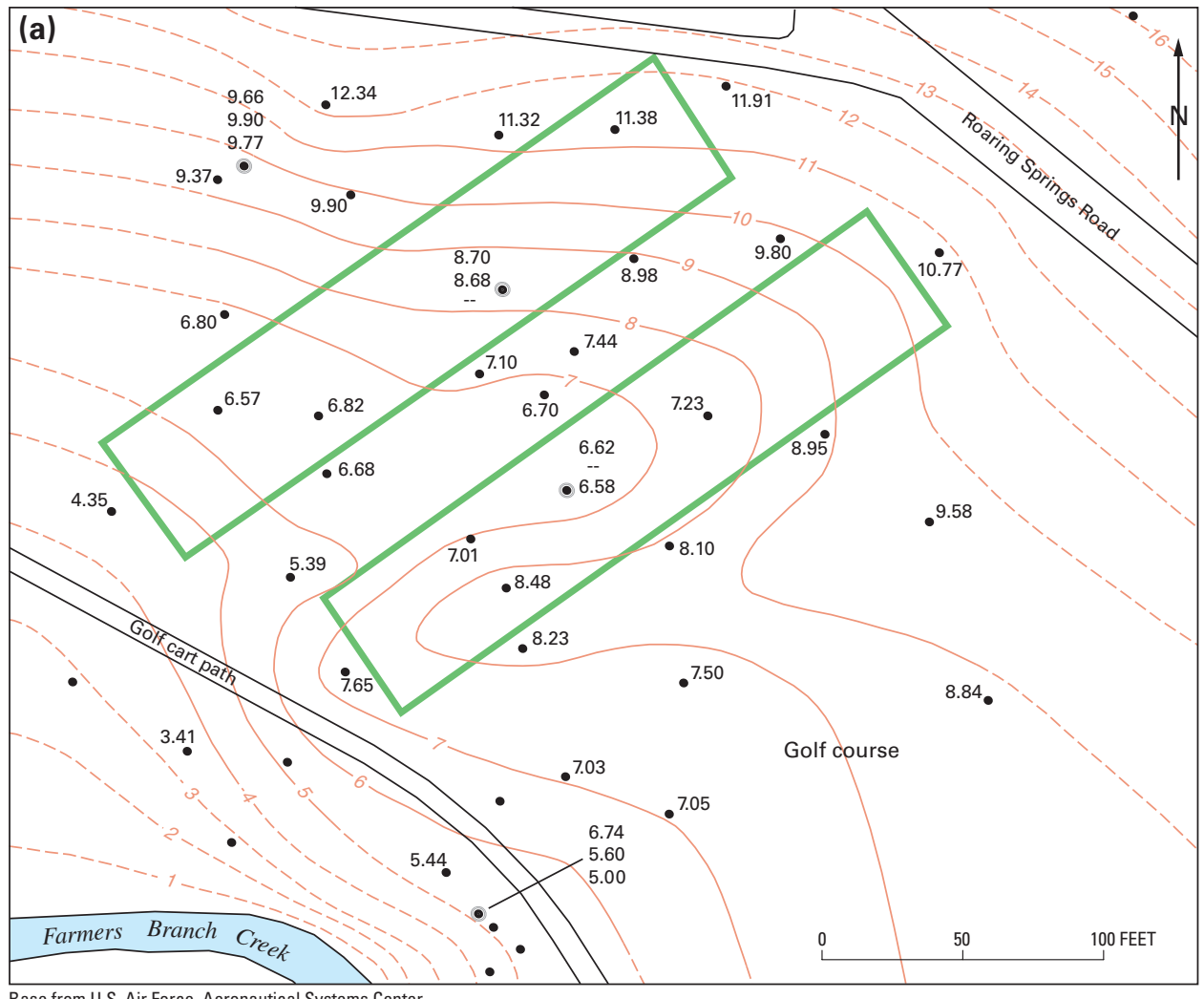

EXPLANATION

Approximate extent of tree plantations

-7 - Line of equal ground-water depth, in feet below land surface-Interval 1 foot

- Well-Number is ground-water

58 depth, in feet below land surface

- Nested wells-Numbers are

6.74 ground-water depths, in feet

5.60 below land surface; --, not

5.00 available

- Well-No data for sampling event

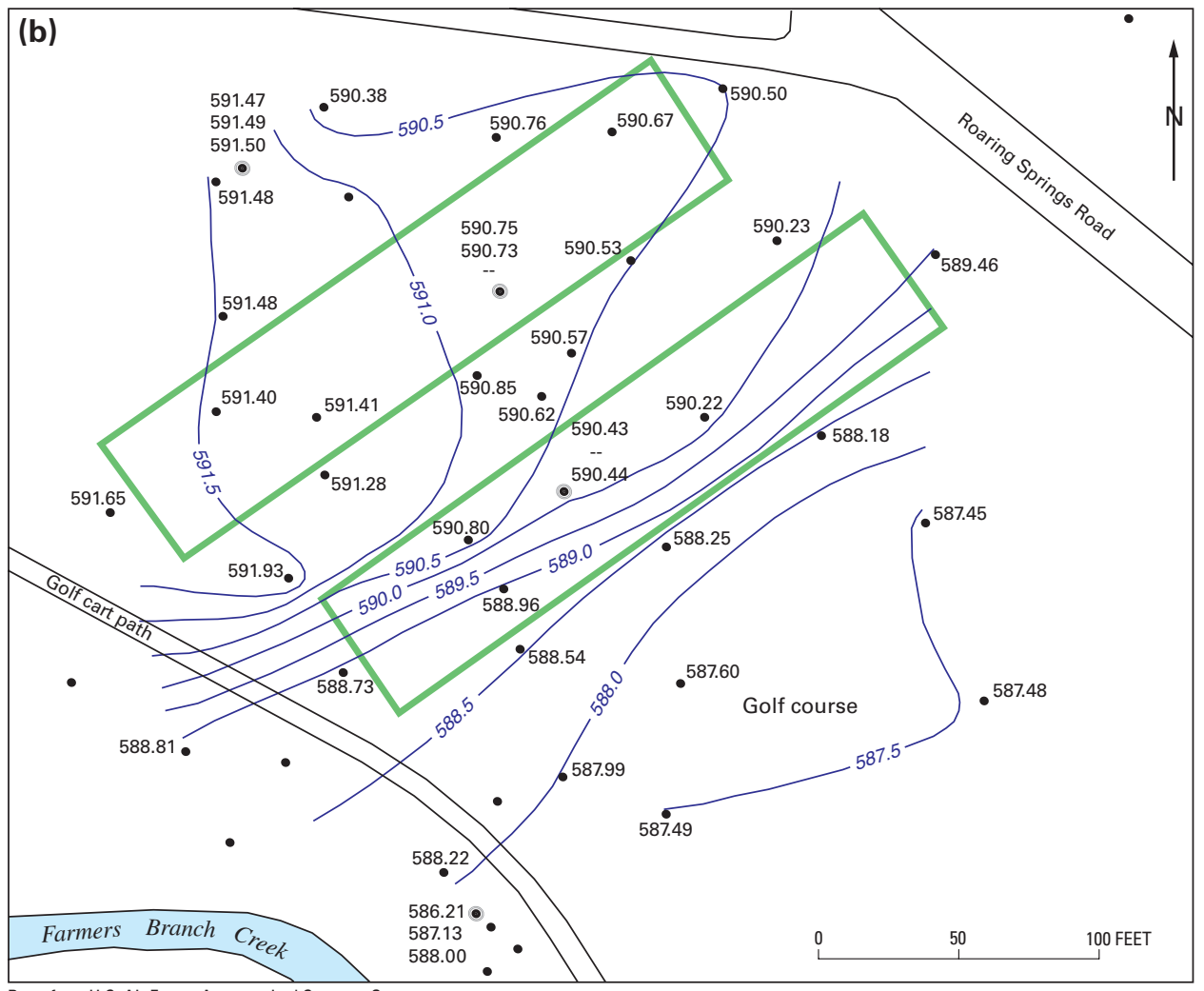

EXPLANATION

Approximate extent of tree plantations

-590.0-Water-table contour-Shows altitude of water table, in

feet above NAVD 88. Contour interval 0.5 foot

- Well-Number is altitude of water level, in feet above NAVD 88

- Nested wells-Numbers are 591.47 altitudes of water levels, in 591.49 feet above NAVD 88; --, not 591.50 available

- Well-No data for sampling event

Figure A-2. (a) Lines of equal ground-water depths and (b) water-level altitude contours for 0ct. 28, 1997. 

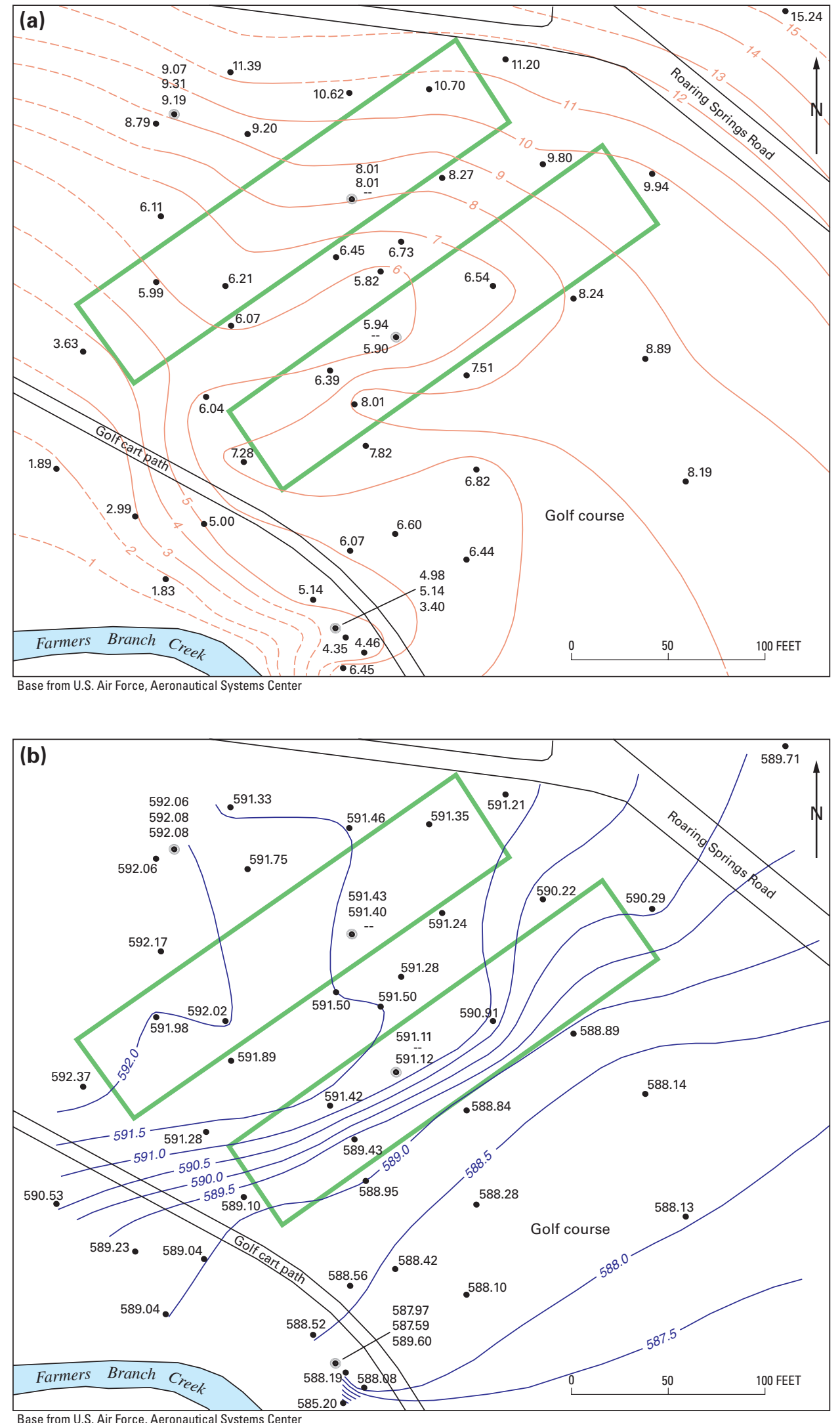

EXPLANATION

Approximate extent of tree plantations

-590.0-Water-table contour-Shows altitude of water table, in feet above NAVD 88. Contour interval 0.5 foot

- Well-Number is altitude of 592.06 water level, in feet above NAVD 88

- Nested wells-Numbers are

592.06 altitudes of water levels, in

592.08 feet above NAVD 88; --, not available

Figure A-3. (a) Lines of equal ground-water depths and (b) water-level altitude contours for Feb. 11, 1998. 


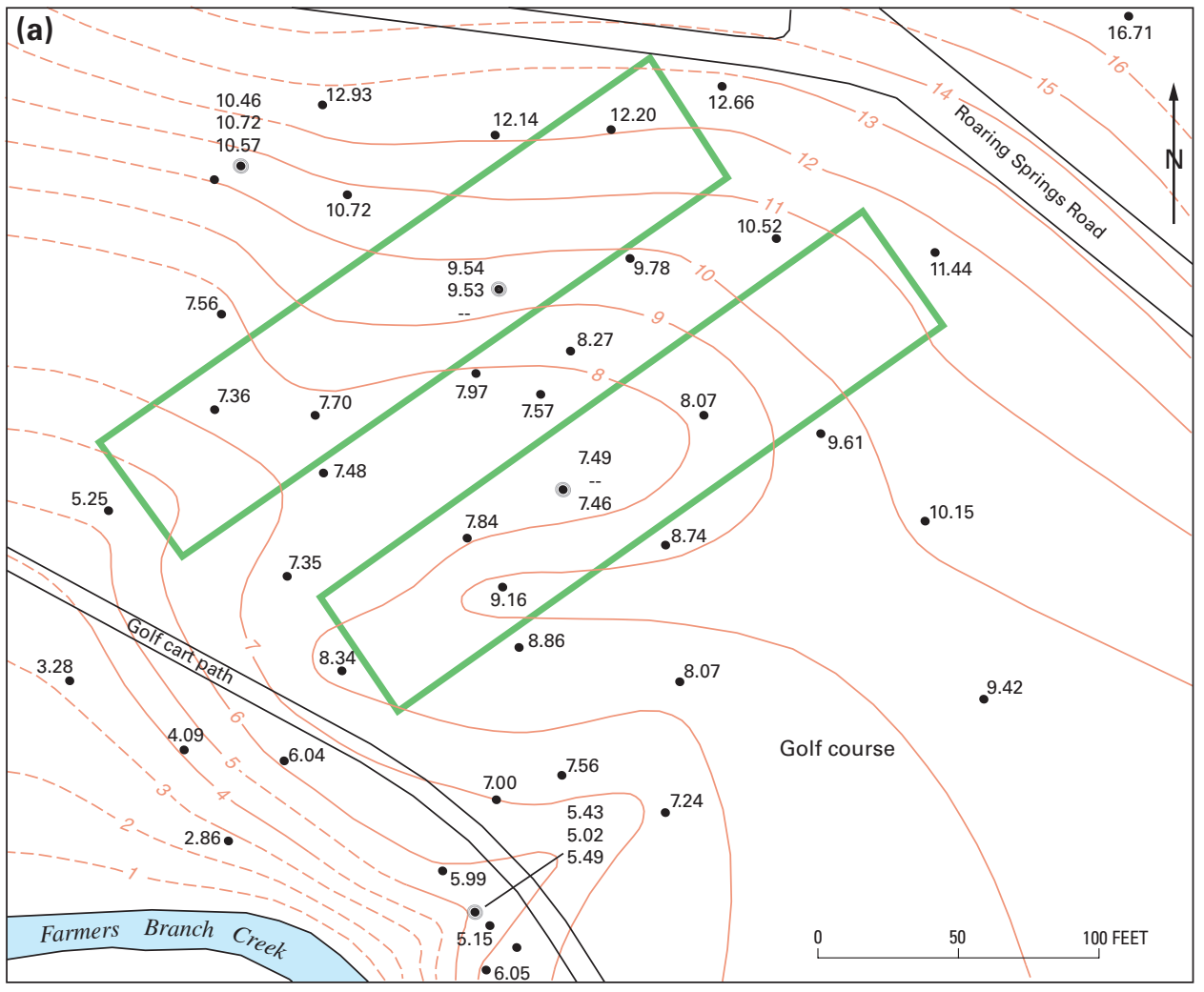

EXPLANATION

Approximate extent of tree plantations

-7- Line of equal ground-water depth, in feet below land surface-Interval 1 foot

- Well-Number is ground-water depth, in feet below land surface

- Nested wells-Numbers are

5.43 ground-water depths, in feet

5.02 below land surface; --, not

5.49 available

- Well-No data for sampling event

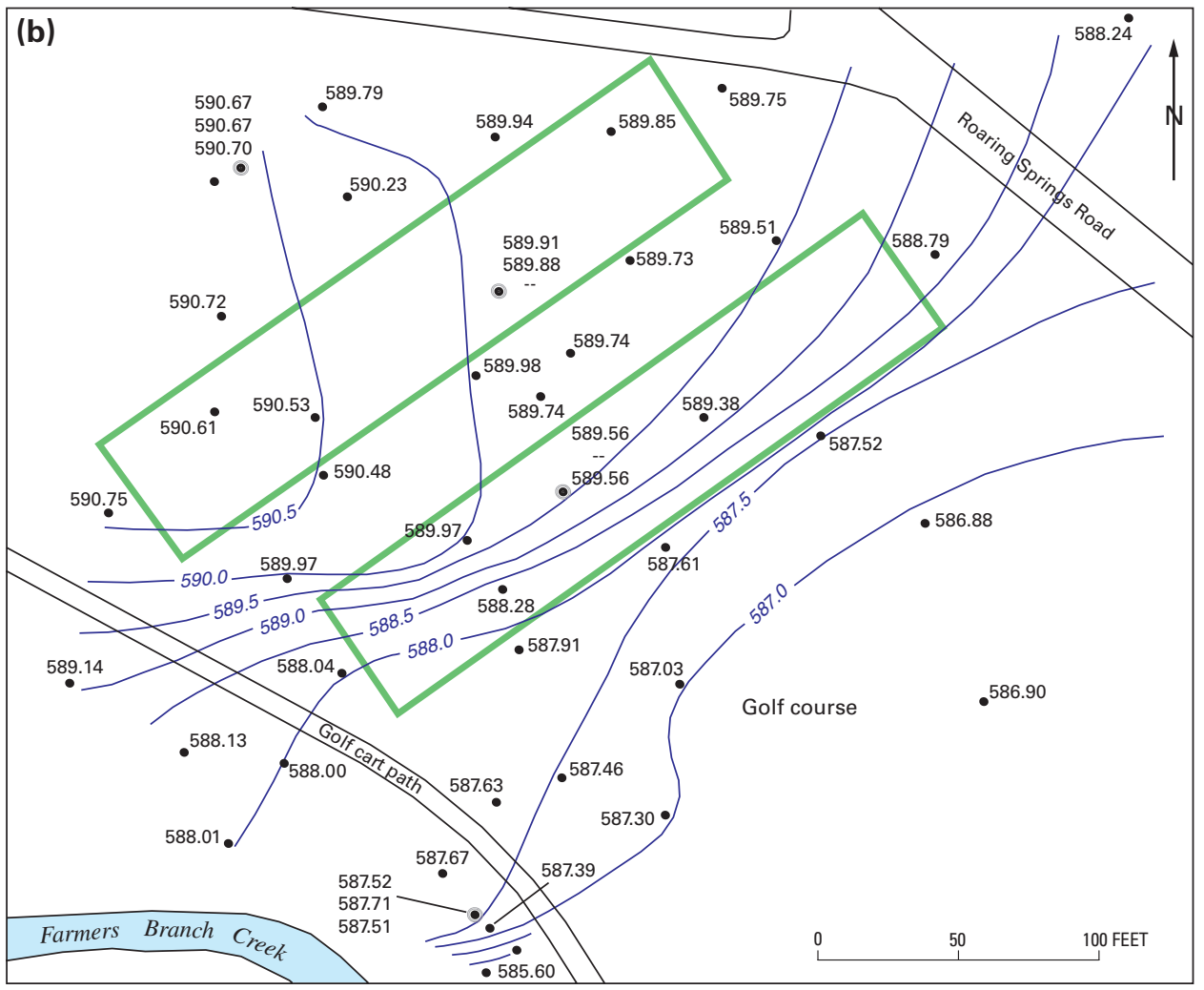

EXPLANATION

Approximate extent of tree plantations

-590.0-Water-table contour-Shows altitude of water table, in feet above NAVD 88. Contour interval 0.5 foot

- Well-Number is altitude of water level, in feet above NAVD 88

- Nested wells-Numbers are 590.67 altitudes of water levels, in 590.67 feet above NAVD 88; --, not 590.70 available

- Well-No data for sampling

Base from U.S. Air Force, Aeronautical Systems Cente

Figure A-4. (a) Lines of equal ground-water depths and (b) water-level altitude contours for June 22, 1998. 


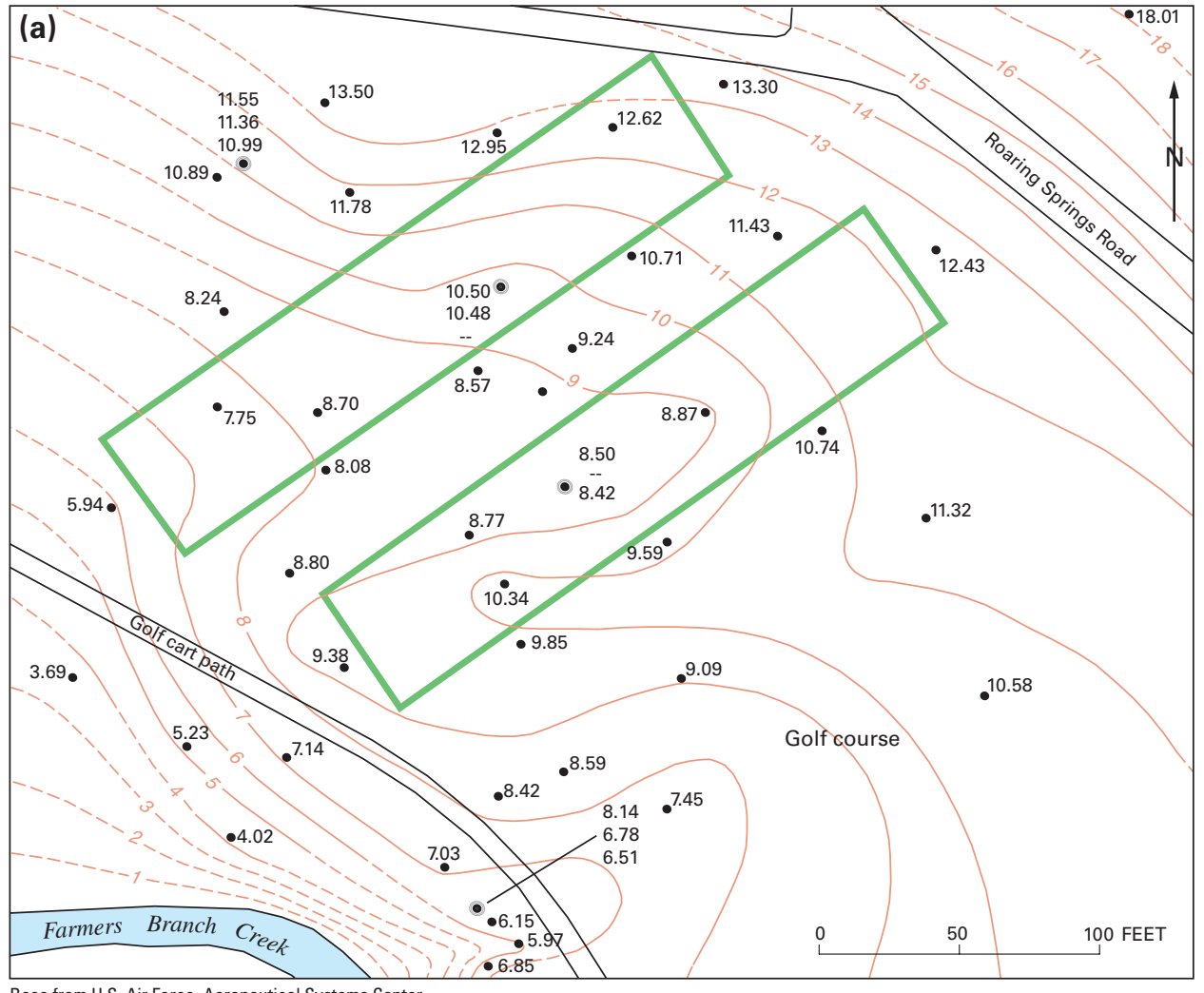

EXPLANATION

Approximate extent of tree plantations

-7- Line of equal ground-water depth, in feet below land surface-Interval 1 foot

- Well-Number is ground-water depth, in feet below land surface

- Nested wells-Numbers are

8.14 ground-water depths, in feet

6.78 below land surface; --, not

6.51 available

- Well-No data for sampling event

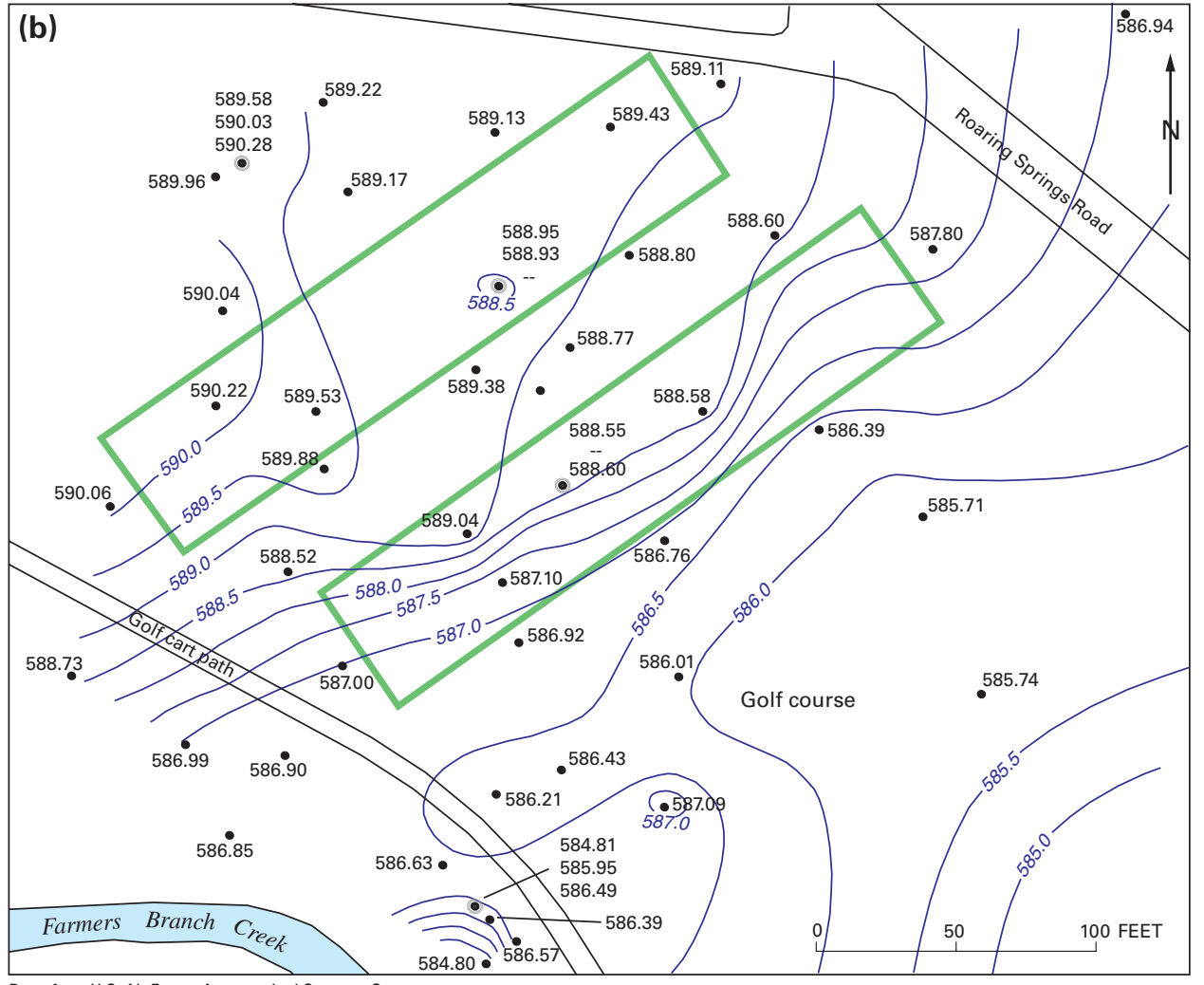

\section{EXPLANATION}

Approximate extent of tree plantations

-590.0-Water-table contour-Shows altitude of water table, in feet above NAVD 88. Contour interval 0.5 foot

- Well-Number is altitude of 4 water level, in feet above NAVD 88

- Nested wells-Numbers are 589.58 altitudes of water levels, in 590.03 feet above NAVD 88; --, not available

- Well-No data for sampling event

Figure A-5. (a) Lines of equal ground-water depths and (b) water-level altitude contours for 0 ct. 10, 2000. 


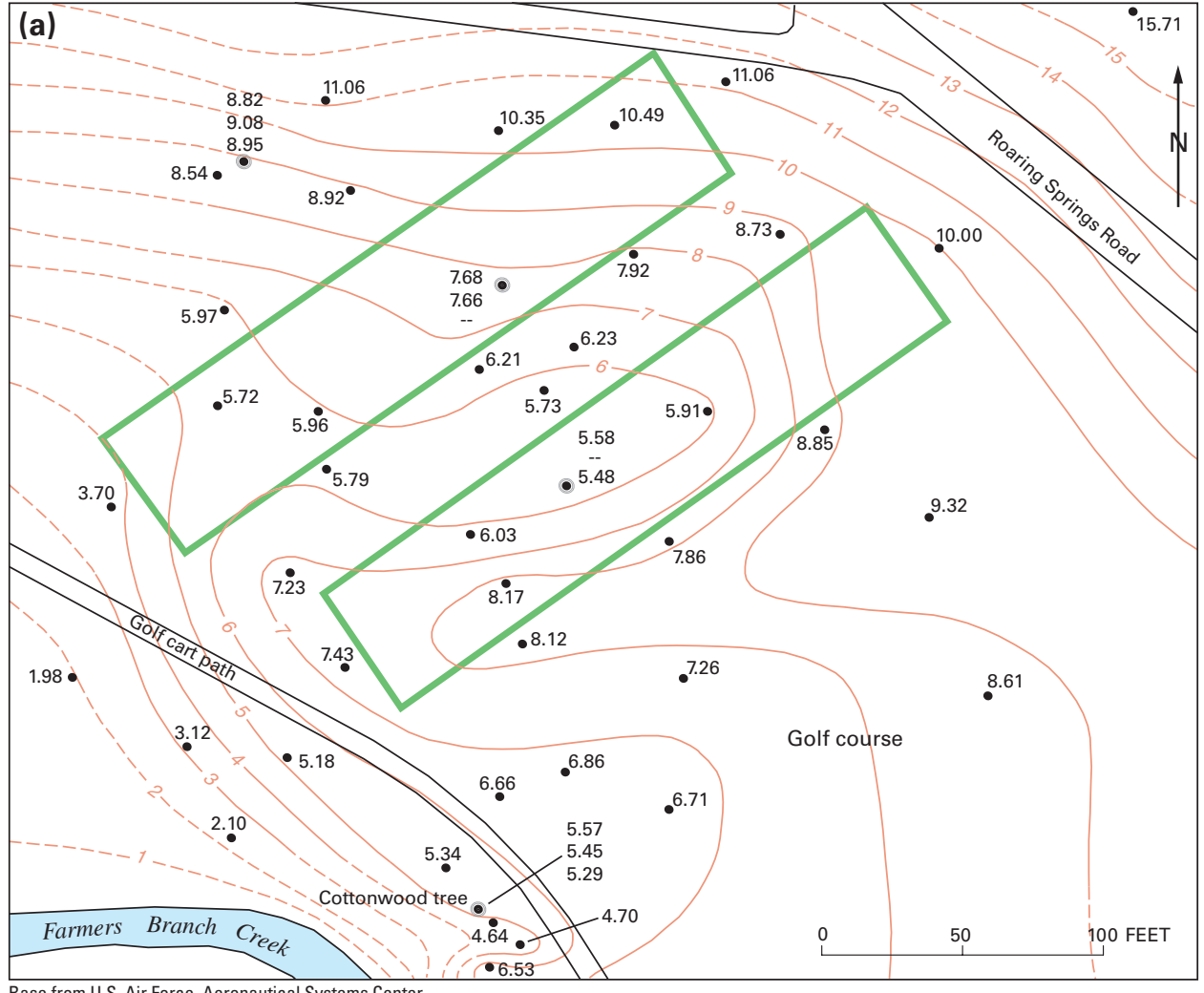

Base from U.S. Air Force, Aeronautical Systems Center

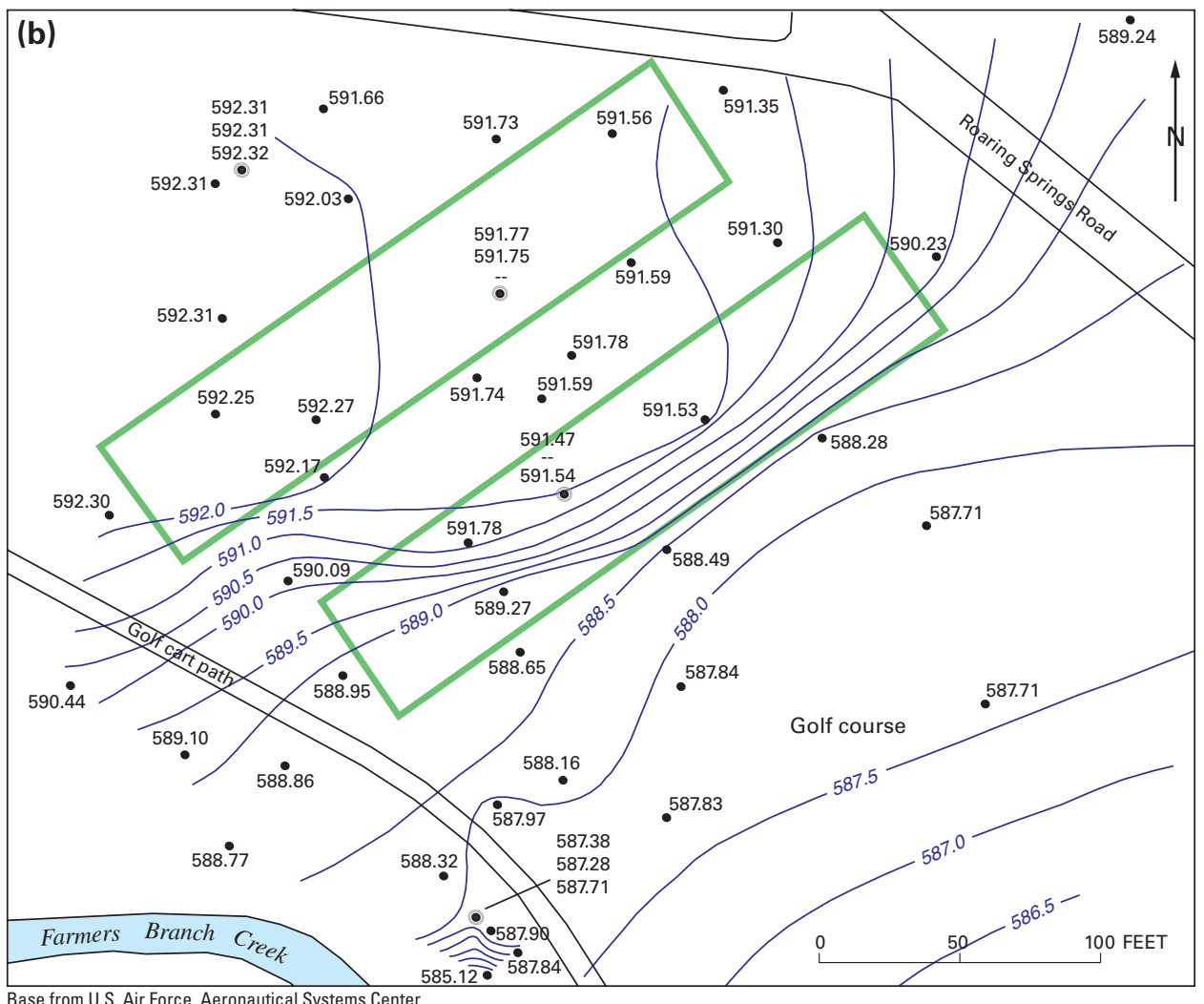

EXPLANATION

Approximate extent of tree plantations

-590.0-Water-table contour-Shows altitude of water table, in feet above NAVD 88. Contour interval 0.5 foot

- Well-Number is altitude of water level, in feet above NAVD 88

- Nested wells-Numbers are 52.31 altitudes of water levels, in 592.31 feet above NAVD 88; --, not 592.32 feet above

Figure A-6. (a) Lines of equal ground-water depths and (b) water-level altitude contours for Jan. 8, 2001. 


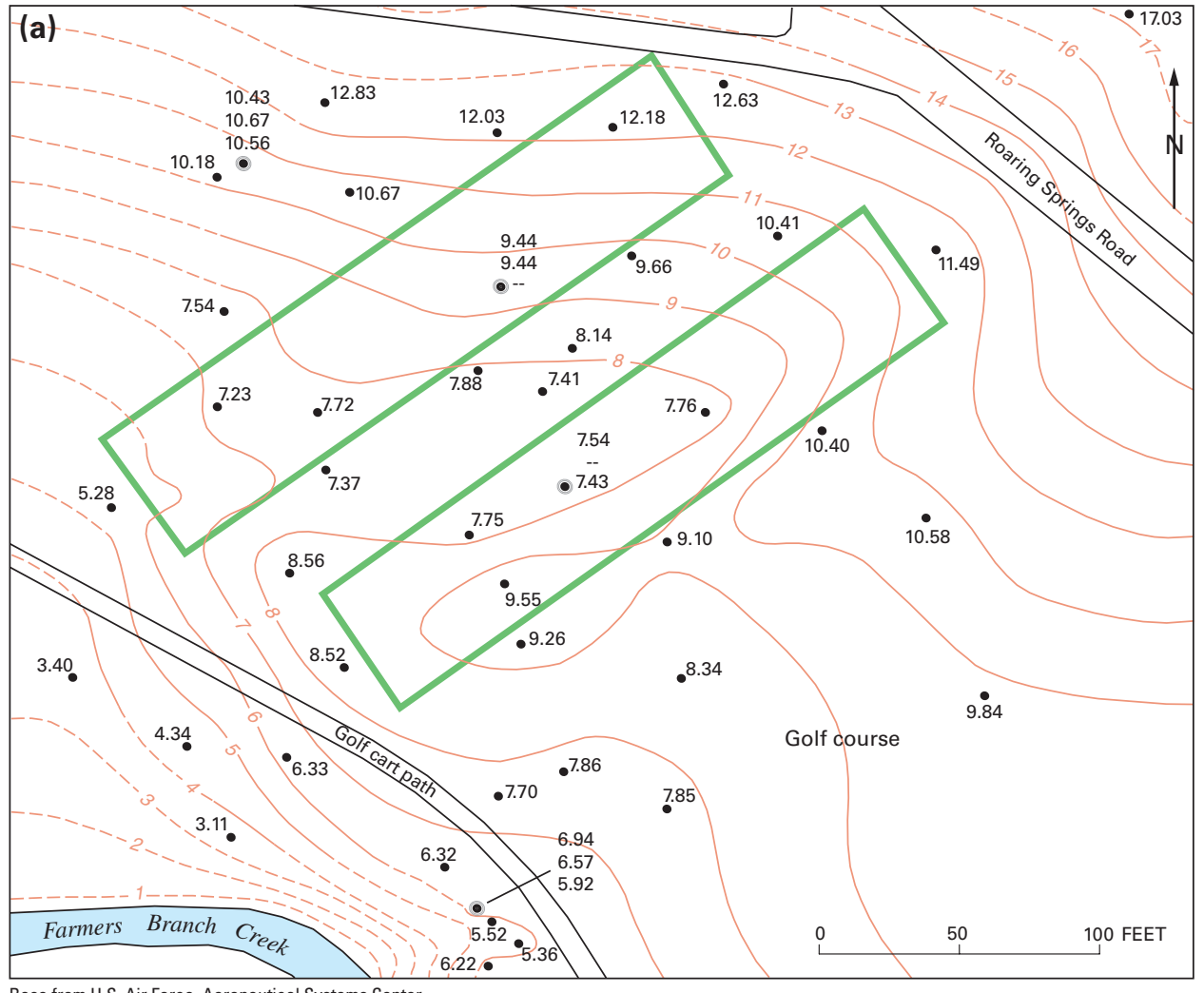

EXPLANATION

Approximate extent of tree plantations

- 7 - Line of equal ground-water depth, in feet below land surface-Interval 1 foot

- Well-Number is ground-water depth, in feet below land surface

- Nested wells-Numbers are 6.94 ground-water depths, in feet

6.57 below land surface; --, not

5.92 available

Base from U.S. Air Force, Aeronautical Systems Cente

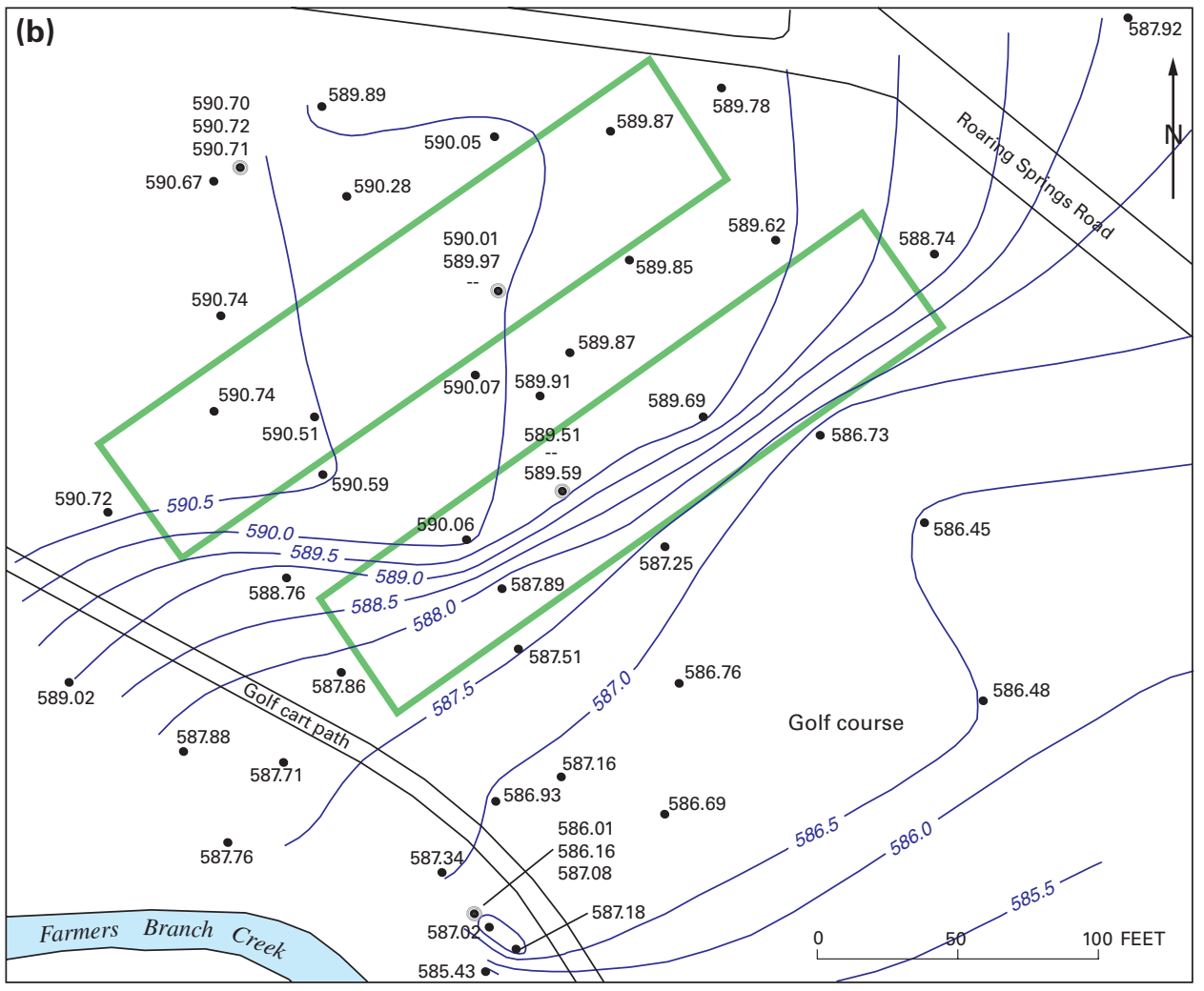

EXPLANATION

Approximate extent of tree plantations

-590.0-Water-table contour-Shows altitude of water table, in feet above NAVD 88. Contour interval 0.5 foot

- Well-Number is altitude of water level, in feet above NAVD 88

- Nested wells-Numbers are 590.70 altitudes of water levels, in 590.72 feet above NAVD 88; --, not 590.71 feet above

Base from U.S. Air Force, Aeronautical Systems Center

Figure A-7. (a) Lines of equal ground-water depths and (b) water-level altitude contours for July 12-13, 2001. 


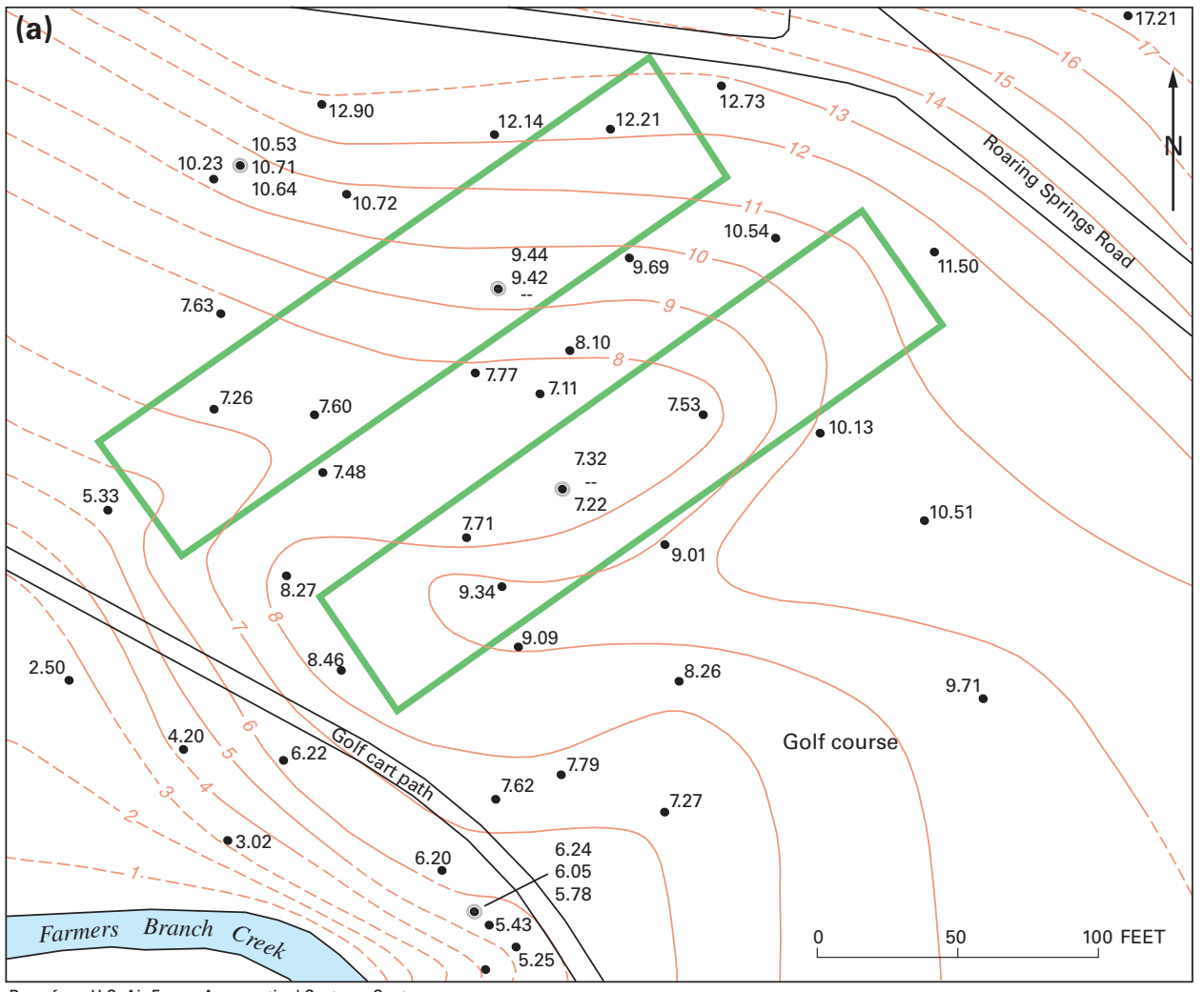

EXPLANATION

Approximate extent of tree plantations

- 7 - Line of equal ground-water depth, in feet below land surface-Interval 1 foot

- Well-Number is ground-water

depth, in feet below land surface

- Nested wells-Numbers are

6.24 ground-water depths, in feet

6.05 below land surface; --, not

5.78 available

- Well-No data for sampling event

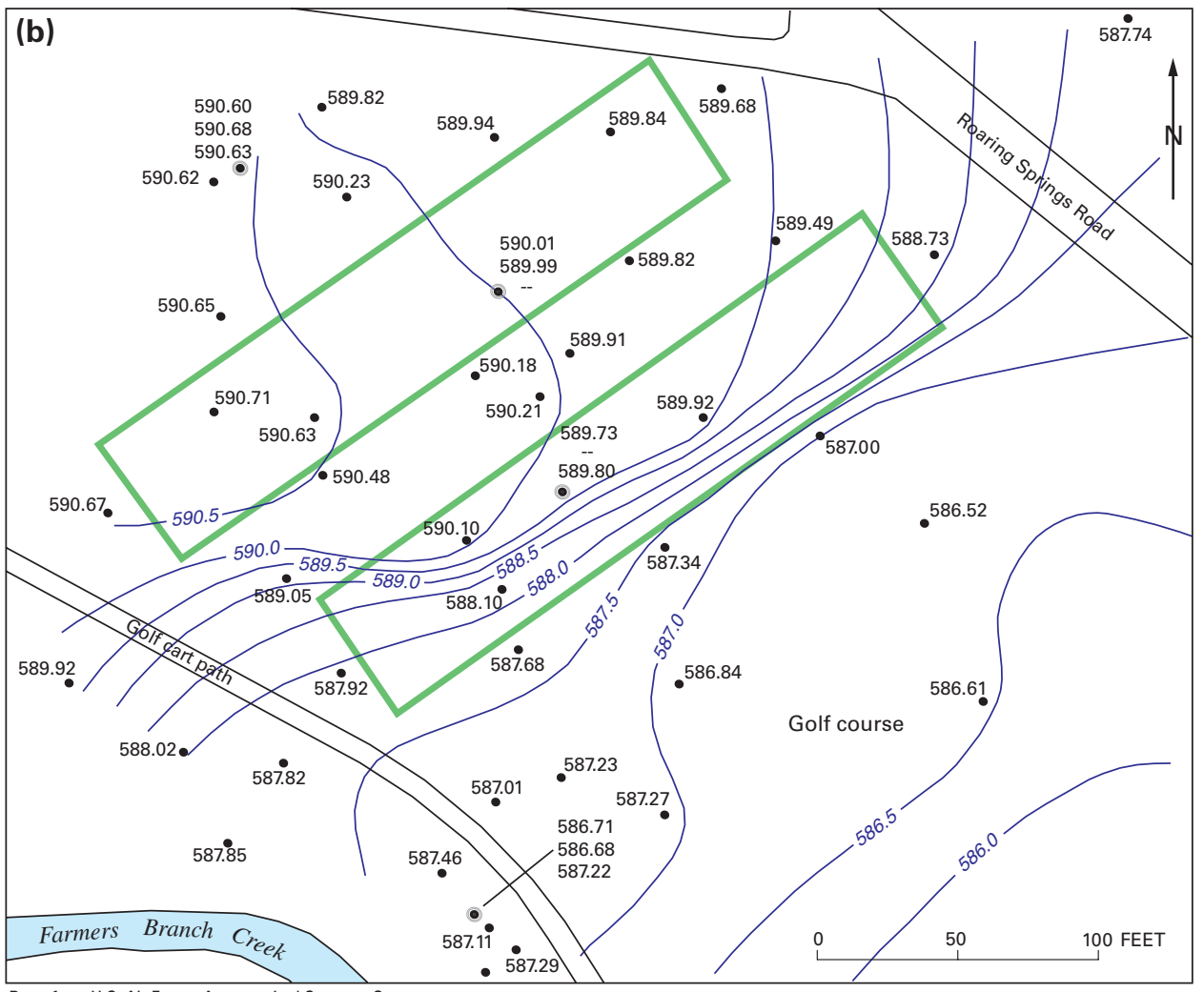

EXPLANATION

Approximate extent of tree plantations

-590.0-Water-table contour-Shows altitude of water table, in feet above NAVD 88. Contour interval 0.5 foot

- Well-Number is altitude of water level, in feet above NAVD 88

- Nested wells-Numbers are 590.60 altitudes of water levels, in 590.68 feet above NAVD 88; --, not 590.63 available

- Well-No data for sampling event

Figure A-8. (a) Lines of equal ground-water depths and (b) water-level altitude contours for Jan. 15-16, 2002. 


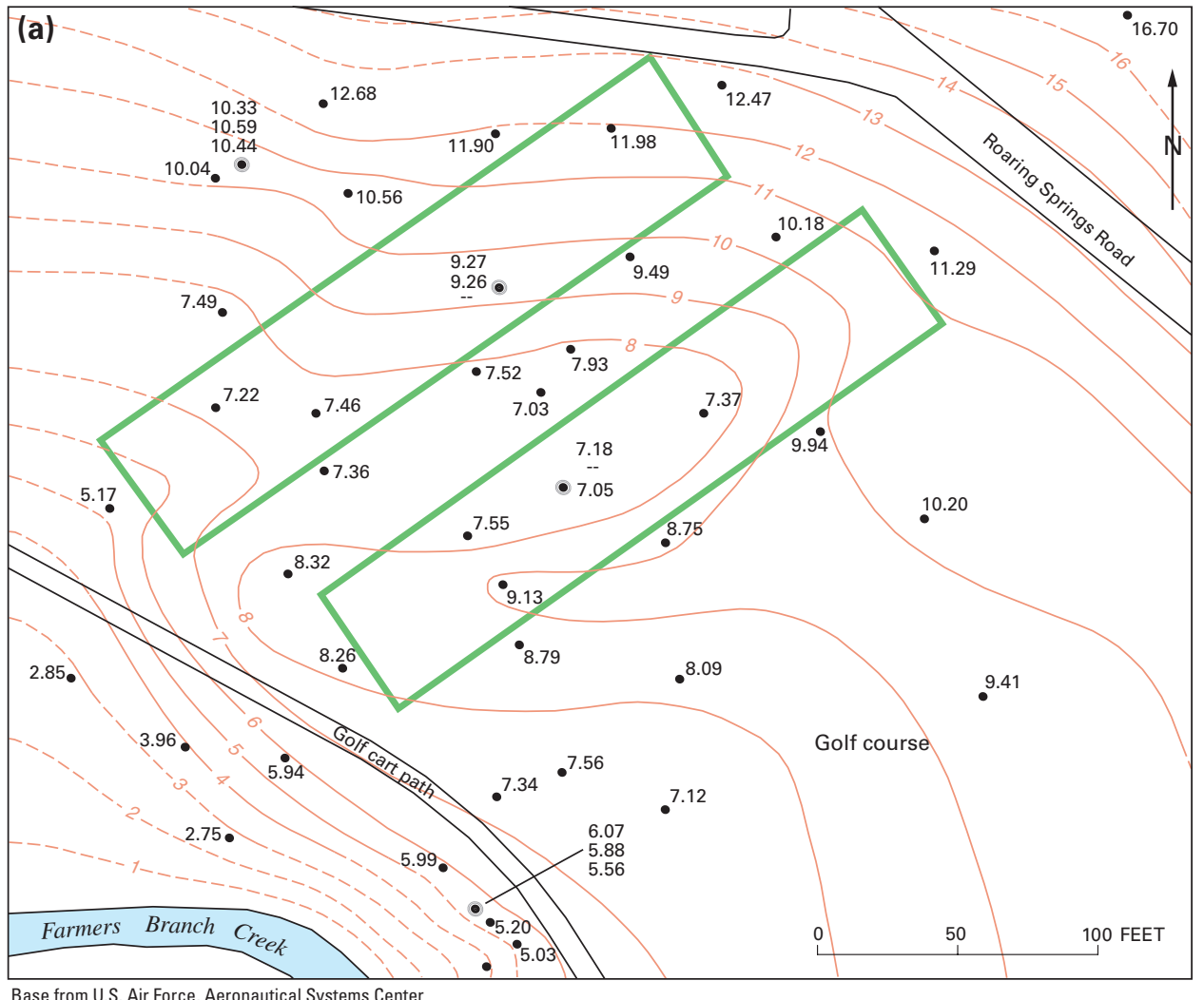

EXPLANATION

Approximate extent of tree plantations

-7 - Line of equal ground-water depth, in feet below land surface-Interval 1 foot

- Well-Number is ground-water depth, in feet below land surface

- Nested wells-Numbers are 6.07 ground-water depths, in feet

5.88 below land surface; --, not

5.56 available

- Well-No data for sampling event

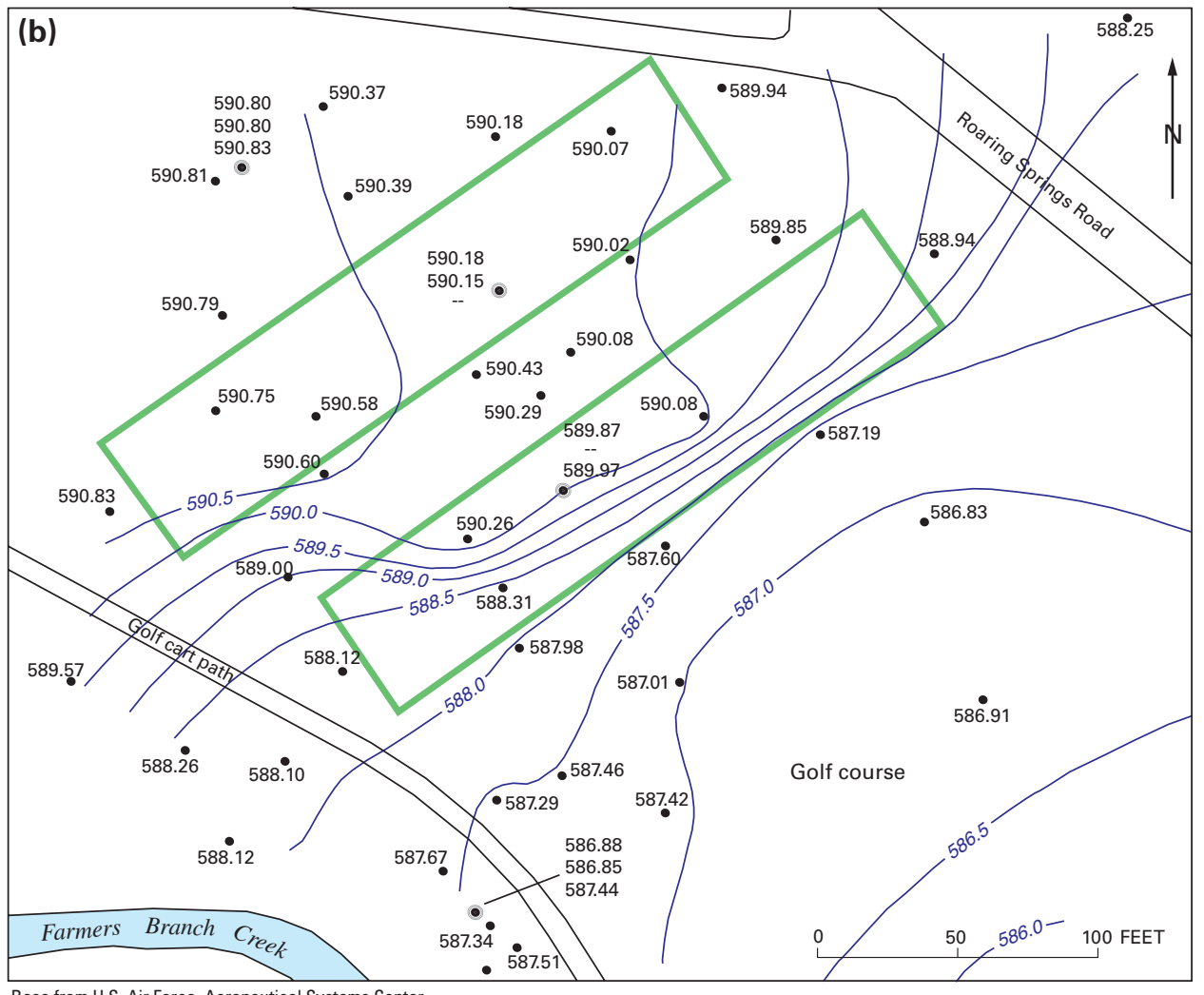

\section{EXPLANATION}

Approximate extent of tree plantations

-590.0-Water-table contour-Shows altitude of water table, in feet above NAVD 88. Contour interval 0.5 foot

- Well-Number is altitude of water level, in feet above NAVD 88

- Nested wells-Numbers are 590.80 altitudes of water levels, in 590.80 feet above NAVD 88; --, not available

- Well-No data for sampling event

Figure A-9. (a) Lines of equal ground-water depths and (b) water-level altitude contours for July 18-19, 2002. 


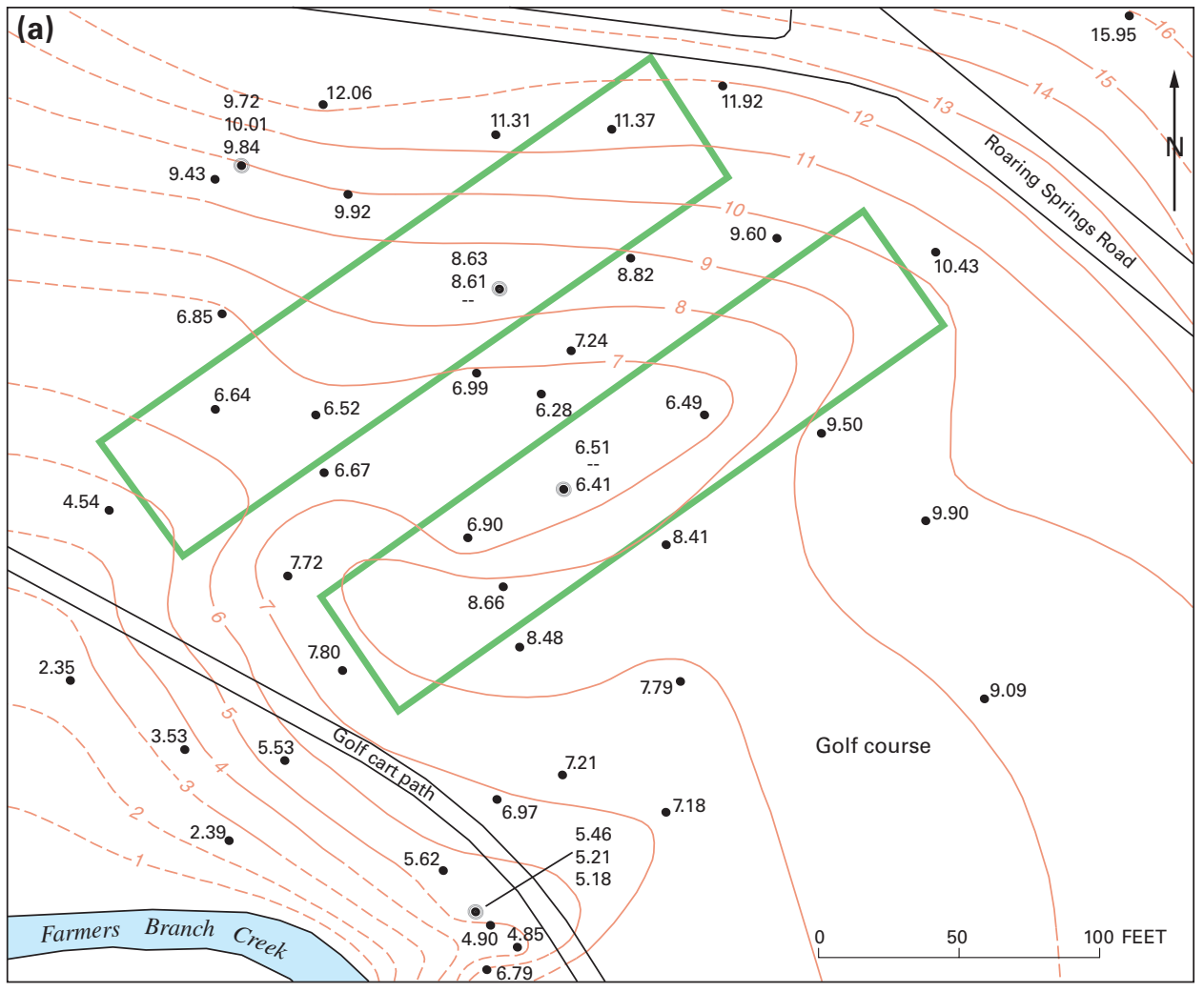

EXPLANATION

Approximate extent of tree plantations

-7- Line of equal ground-water depth, in feet below land surface-Interval 1 foot

- Well-Number is ground-water depth, in feet below land surface

- Nested wells-Numbers are

5.46 ground-water depths, in feet

5.21 below land surface; --, not

5.18 available

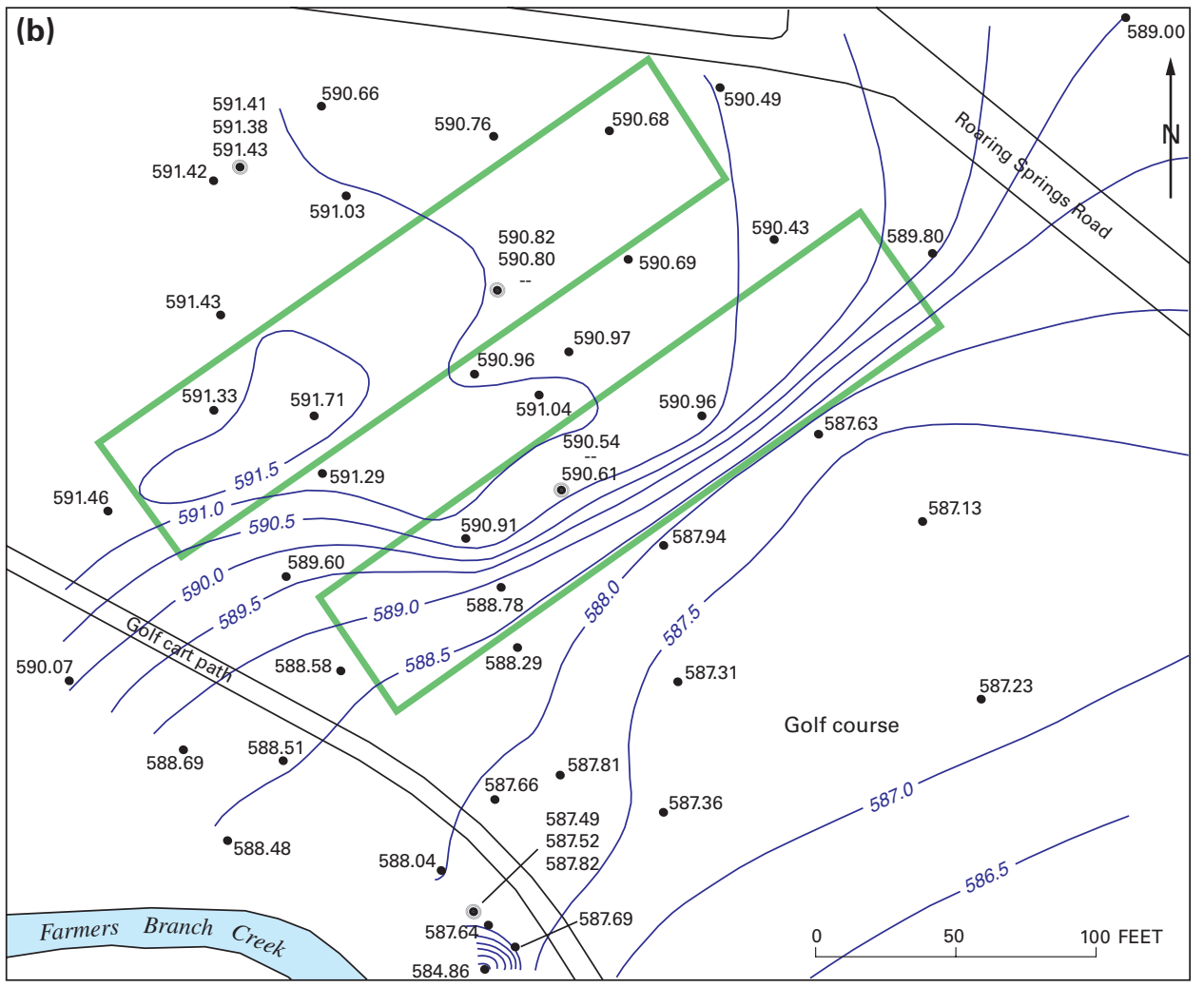

EXPLANATION

Approximate extent of tree plantations

-590.0-Water-table contour-Shows altitude of water table, in

feet above NAVD 88. Contour interval 0.5 foot

Well-Number is altitude of water level, in feet above NAVD 88

- Nested wells-Numbers are 591.41 altitudes of water levels, in 591.38 feet above NAVD 88; --, not 591.43 available

Base from U.S. Air Force, Aeronautical Systems Center

Figure A-10. (a) Lines of equal ground-water depths and (b) water-level altitude contours for Jan. 14-15, 2003. 
Table A-1. Well-construction data.

[--, not available]

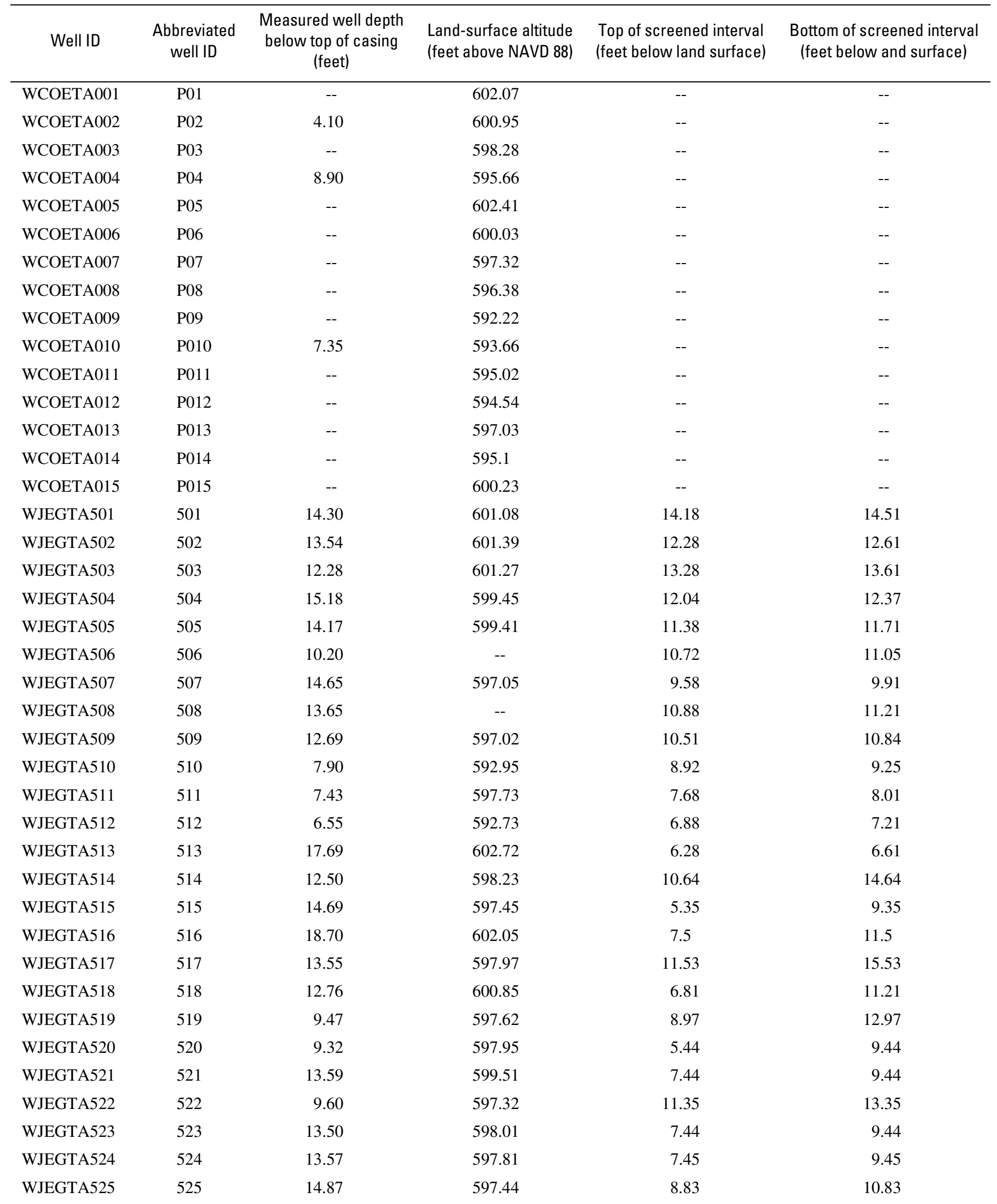


34 Water-Level Variations and Their Effects on Tree Growth and Mortality and on the Biogeochemical System, 1996-2003

Table A-1. Well-construction data-Continued.

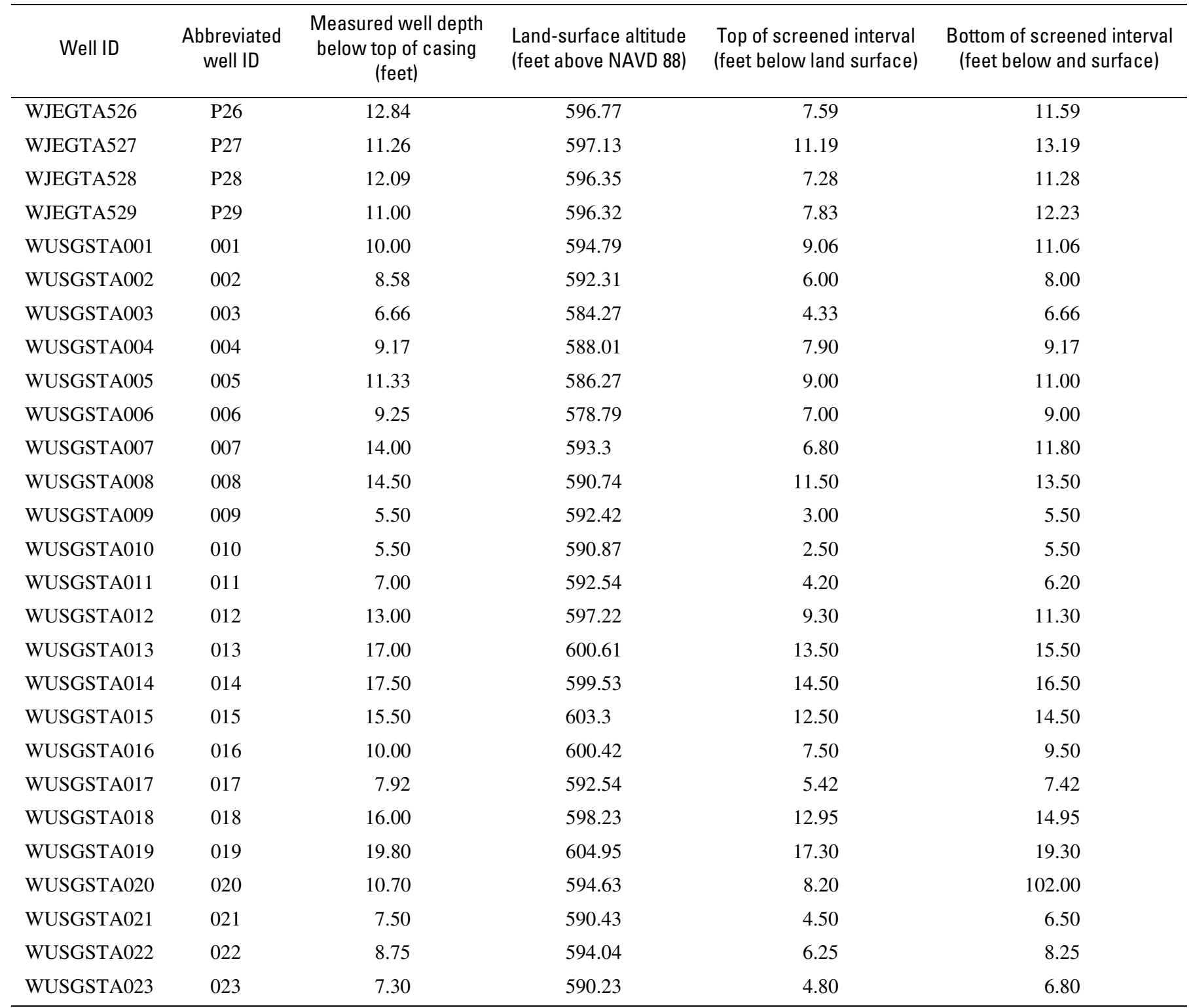


Table A-2. Trichloroethene concentrations from six sampling events.

[In micrograms per liter $(\mu \mathrm{g} / \mathrm{L})$; to convert to micromoles per liter, divide by atomic mass of trichloroethene, $131.38 \mu \mathrm{g} / \mathrm{L}$; --, not sampled; $\mathrm{Q}$, elevated reporting limit]

\begin{tabular}{|c|c|c|c|c|c|c|}
\hline \multicolumn{7}{|c|}{ Sampling event } \\
\hline Well ID & June 1998 & Sept. 2000 & Jan. 2001 & July 2001 & Jan.-Feb. 2002 & July 2002 \\
\hline WCOETA002 & -- & -- & -- & -- & 170 & 170 \\
\hline WCOETA004 & -- & -- & 210 & 270 & 200 & 170 \\
\hline WCOETA006 & -- & -- & -- & -- & -- & 170 \\
\hline WCOETA010 & -- & -- & 160 & 110 & 120 & 130 \\
\hline WJEGTA501 & 460 & -- & 180 & 200 & 170 & 160 \\
\hline WJEGTA502 & 510 & 160 & 200 & 240 & 140 & 170 \\
\hline WJEGTA503 & 530 & -- & 200 & 180 & 150 & 180 \\
\hline WJEGTA504 & 560 & -- & 150 & 180 & 140 & 130 \\
\hline WJEGTA505 & 490 & -- & 160 & 200 & 170 & 120 \\
\hline WJEGTA507 & 440 & -- & 150 & 210 & 190 & 150 \\
\hline WJEGTA508 & 450 & -- & 130 & 190 & 160 & 180 \\
\hline WJEGTA509 & 500 & -- & 110 & 180 & 150 & 150 \\
\hline WJEGTA510 & 48 & -- & 32 & -- & 7.8 & 2 \\
\hline WJEGTA511 & 64 & 45 & 64 & 41 & 43 & 11 \\
\hline WJEGTA512 & 360 & -- & 150 & 100 & 77 & 110 \\
\hline WJEGTA513 & -- & -- & 230 & 230 & 150 & 180 \\
\hline WJEGTA514 & 423 & 120 & 72 & 110 & 130 & 150 \\
\hline WJEGTA515 & 390 & 60 & 34 & 160 & 51 & 130 \\
\hline WJEGTA516 & 540 & 240 & 160 & 270 & 230 & 170 \\
\hline WJEGTA517 & 470 & -- & 190 & 250 & 190 & Q200 \\
\hline WJEGTA518 & 420 & 200 & 150 & 220 & 190 & 170 \\
\hline WJEGTA519 & 600 & 190 & 180 & 230 & 140 & 130 \\
\hline WJEGTA520 & 450 & -- & 150 & 200 & 170 & 190 \\
\hline WJEGTA521 & 580 & -- & 180 & 240 & 170 & 180 \\
\hline WJEGTA522 & -- & -- & 200 & 210 & 190 & 180 \\
\hline WJEGTA523 & 500 & -- & 170 & 190 & 190 & 160 \\
\hline WJEGTA524 & 600 & 220 & 180 & 230 & 180 & 180 \\
\hline WJEGTA525 & 460 & -- & 140 & 210 & 130 & 150 \\
\hline WJEGTA526 & 490 & 240 & 150 & 220 & 180 & 160 \\
\hline WJEGTA527 & 540 & -- & 40 & 110 & 12 & Q51 \\
\hline WJEGTA528 & 380 & -- & 24 & 75 & 1.2 & 47 \\
\hline WJEGTA529 & 500 & -- & 150 & 220 & 170 & 160 \\
\hline WUSGSTA011 & -- & -- & 170 & 140 & 150 & 150 \\
\hline WUSGSTA017 & -- & -- & 170 & 160 & 150 & 130 \\
\hline WUSGSTA020 & -- & -- & 170 & 200 & 150 & 160 \\
\hline WUSGSTA021 & -- & -- & -- & -- & 75 & -- \\
\hline
\end{tabular}


Table A-3. cis-Dichloroethene concentrations from six sampling events.

[In micrograms per liter $(\mu \mathrm{g} / \mathrm{L})$; to convert to micromoles per liter, divide by atomic mass of $c i s$-dichloroethene, $96.94 \mu \mathrm{g} / \mathrm{L}$; --, not sampled]

\begin{tabular}{|c|c|c|c|c|c|c|}
\hline \multicolumn{7}{|c|}{ Sampling event } \\
\hline Well ID & Jun. 1998 & Sept. 2000 & Jan. 2001 & July 2001 & Jan.-Feb. 2002 & July 2002 \\
\hline WCOETA002 & -- & -- & -- & -- & 28 & 29 \\
\hline WCOETA004 & -- & -- & 54 & 55 & 53 & 38 \\
\hline WCOETA006 & -- & -- & -- & -- & -- & 31 \\
\hline WCOETA010 & -- & -- & 44 & 33 & 57 & 46 \\
\hline WJEGTA501 & 110 & -- & 31 & 37 & 30 & 26 \\
\hline WJEGTA502 & 130 & 33 & 34 & 40 & 27 & 28 \\
\hline WJEGTA503 & 130 & -- & 34 & 33 & 30 & 29 \\
\hline WJEGTA504 & 120 & -- & 50 & 39 & 45 & 26 \\
\hline WJEGTA505 & 110 & -- & 39 & 38 & 35 & 21 \\
\hline WJEGTA507 & 91 & -- & 69 & 45 & 36 & 28 \\
\hline WJEGTA508 & 95 & -- & 83 & 40 & 33 & 33 \\
\hline WJEGTA509 & 100 & -- & 71 & 40 & 33 & 30 \\
\hline WJEGTA510 & 140 & -- & 77 & -- & 83 & 49 \\
\hline WJEGTA511 & 170 & 120 & 74 & 57 & 59 & 53 \\
\hline WJEGTA512 & 140 & -- & 55 & 60 & 43 & 44 \\
\hline WJEGTA513 & -- & -- & 39 & 43 & 33 & 30 \\
\hline WJEGTA514 & 150 & 47 & 72 & 82 & 51 & 47 \\
\hline WJEGTA515 & 92 & 24 & 31 & 45 & 25 & 32 \\
\hline WJEGTA516 & 120 & 47 & 52 & 46 & 42 & 30 \\
\hline WJEGTA517 & 110 & -- & 39 & 46 & 44 & 30 \\
\hline WJEGTA518 & 100 & 39 & 29 & 39 & 30 & 26 \\
\hline WJEGTA519 & 140 & 53 & 53 & 68 & 37 & 45 \\
\hline WJEGTA520 & 92 & -- & 55 & 41 & 32 & 31 \\
\hline WJEGTA521 & 120 & -- & 41 & 44 & 30 & 29 \\
\hline WJEGTA522 & -- & -- & 37 & 38 & 33 & 30 \\
\hline WJEGTA523 & 100 & -- & 45 & 36 & 38 & 28 \\
\hline WJEGTA524 & 130 & 48 & 44 & 44 & 37 & 35 \\
\hline WJEGTA525 & 95 & -- & 42 & 49 & 32 & 33 \\
\hline WJEGTA526 & 99 & 47 & 50 & 45 & 40 & 33 \\
\hline WJEGTA527 & 120 & -- & 100 & 48 & 41 & 16 \\
\hline WJEGTA528 & 75 & -- & 34 & 42 & 1.9 & 15 \\
\hline WJEGTA529 & 97 & -- & 58 & 46 & 44 & 33 \\
\hline WUSGSTA011 & -- & -- & 43 & 28 & 44 & 32 \\
\hline WUSGSTA017 & -- & -- & 40 & 33 & 50 & 43 \\
\hline WUSGSTA020 & -- & -- & 43 & 39 & 42 & 35 \\
\hline WUSGSTA021 & -- & -- & -- & -- & 55 & -- \\
\hline
\end{tabular}


Table A-4. Molar ratios of trichloroethene to cis-dichloroethene from six sampling events.

[--, not sampled]

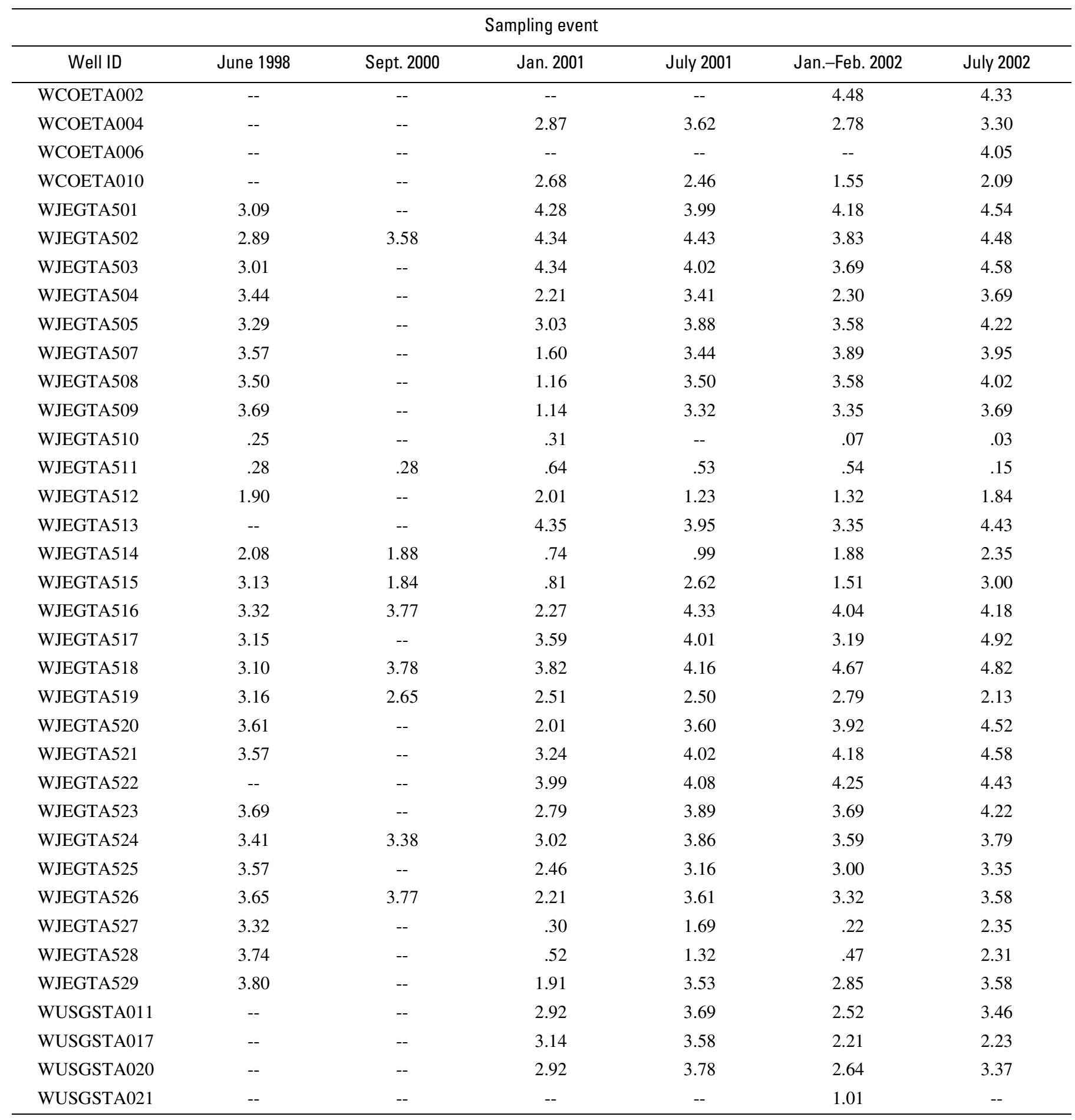


Table A-5. Dissolved oxygen concentrations from six sampling events.

[In milligrams per liter; --, not sampled]

\begin{tabular}{|c|c|c|c|c|c|c|}
\hline \multicolumn{7}{|c|}{ Sampling event } \\
\hline Well ID & June 1998 & Sept. 2000 & Jan. 2001 & July 2001 & Jan.-Feb. 2002 & July 2002 \\
\hline WCOETA002 & -- & -- & -- & -- & 3.8 & 2.6 \\
\hline WCOETA004 & -- & -- & 3.2 & 0.40 & 1.11 & .49 \\
\hline WCOETA006 & -- & -- & -- & -- & -- & 1.80 \\
\hline WCOETA010 & 1.36 & -- & 2.3 & .20 & 1.01 & .20 \\
\hline WJEGTA501 & 4.7 & -- & 5.5 & 3.1 & 3.5 & 2.6 \\
\hline WJEGTA502 & 3.7 & 4.3 & 5.5 & 3.3 & 3.4 & 2.8 \\
\hline WJEGTA503 & 4.3 & -- & 5.8 & 3.3 & 4.3 & 2.8 \\
\hline WJEGTA504 & 4.3 & -- & 1.2 & 1.50 & 2.08 & 2.6 \\
\hline WJEGTA505 & 4.8 & -- & 2.6 & 1.80 & 1.90 & 2.1 \\
\hline WJEGTA507 & 4.5 & -- & 1.3 & 1.44 & 1.30 & 2.24 \\
\hline WJEGTA508 & 3.8 & -- & .87 & 2.13 & 2.06 & 1.90 \\
\hline WJEGTA509 & 4.4 & -- & .47 & 1.99 & 1.02 & 1.24 \\
\hline WJEGTA510 & .69 & -- & .89 & -- & 1.60 & .44 \\
\hline WJEGTA511 & .75 & .93 & .18 & .85 & 1.11 & .80 \\
\hline WJEGTA512 & .69 & -- & 1.17 & 1.04 & 1.03 & .37 \\
\hline WJEGTA513 & 4.1 & -- & 4.5 & 2.8 & 4.1 & 3.1 \\
\hline WJEGTA514 & 1.68 & 1.7 & .18 & .53 & .34 & .59 \\
\hline WJEGTA515 & 2.9 & 1.6 & .15 & 1.28 & 1.07 & 1.10 \\
\hline WJEGTA516 & 4.3 & 3.8 & 3.2 & 3.3 & 2.0 & 3.01 \\
\hline WJEGTA517 & 1.38 & -- & 3.4 & 1.10 & 3.1 & 1.52 \\
\hline WJEGTA518 & 4.3 & 4.8 & 4.8 & 2.8 & 3.2 & 1.50 \\
\hline WJEGTA519 & 4.4 & 3.2 & 1.6 & 1.20 & .63 & 1.80 \\
\hline WJEGTA520 & 3.8 & -- & 2.0 & 1.80 & 1.70 & 1.14 \\
\hline WJEGTA521 & 3.8 & -- & 3.4 & 2.8 & 1.90 & 2.6 \\
\hline WJEGTA522 & 5.0 & -- & 4.7 & 3.1 & -- & 1.41 \\
\hline WJEGTA523 & 4.5 & -- & 2.3 & 3.1 & -- & 2.1 \\
\hline WJEGTA524 & 4.0 & 4.2 & 2.9 & 1.60 & -- & .30 \\
\hline WJEGTA525 & 3.6 & -- & 3.3 & 2.0 & -- & 1.30 \\
\hline WJEGTA526 & 3.3 & 3.2 & 1.00 & 1.72 & -- & .83 \\
\hline WJEGTA527 & 3.9 & -- & 2.8 & .10 & -- & .80 \\
\hline WJEGTA528 & 1.59 & -- & .45 & .29 & -- & 1.30 \\
\hline WJEGTA529 & 2.7 & -- & 1.56 & 1.92 & -- & 1.14 \\
\hline WUSGSTA011 & 3.3 & -- & 2.0 & 1.53 & -- & .60 \\
\hline WUSGSTA017 & 2.23 & -- & 2.7 & .76 & -- & .33 \\
\hline WUSGSTA020 & 2.9 & -- & 2.6 & 1.20 & -- & .90 \\
\hline WUSGSTA021 & .73 & -- & -- & -- & -- & -- \\
\hline WUSGSTA022 & 2.5 & -- & -- & -- & -- & -- \\
\hline
\end{tabular}


Table A-6. Dissolved organic carbon concentrations from September 2000 sampling event.

[In milligrams per liter]

\begin{tabular}{cc}
\hline Well ID & Concentration \\
\hline WJEGTA502 & 1.1 \\
WJEGTA511 & 1.7 \\
WJEGTA514 & 1.8 \\
WJEGTA515 & 1.6 \\
WJEGTA516 & 0.9 \\
WJEGTA518 & 1.1 \\
WJEGTA519 & 1.3 \\
WJEGTA524 & 1.0 \\
WJEGTA526 & 1.2 \\
\hline
\end{tabular}

Table A-7. Quality-control results for trichloroethene (TCE), cis-dichloroethene (cis-DCE), and molar ratios of TCE to cis-DCE (TCE/cis-DCE) for four of six sampling events.

[dup, duplicate sample; $\mu \mathrm{g} / \mathrm{L}$, micrograms per liter]

$$
\text { January } 2001
$$

Well WJEGTA509 dup $\quad$ TCE - $130 \mu \mathrm{g} / \mathrm{L} ;$ cis-DCE - $72 \mu \mathrm{g} / \mathrm{L}$; TCE/cis-DCE - 1.33

Field blank neither cis-DCE nor TCE were detected

Method blank (3) neither cis-DCE nor TCE were detected

\begin{tabular}{ll}
\hline & \multicolumn{1}{c}{ July 2001 } \\
\hline Well WJEGTA502 dup & TCE - 250 $\mu \mathrm{g} / \mathrm{L} ;$ cis-DCE - 40 $\mu \mathrm{g} / \mathrm{L} ; \mathrm{TCE} /$ cis-DCE - 4.61 \\
Well WJEGTA511 dup & TCE - 41 $\mu \mathrm{g} / \mathrm{L} ;$ cis-DCE - 64 $\mu \mathrm{g} / \mathrm{L}$; TCE/cis-DCE - 0.47 \\
Well WJEGTA525 dup & TCE - 200 $\mu \mathrm{g} / \mathrm{L} ;$ cis-DCE - 49 $\mu \mathrm{g} / \mathrm{L}$; TCE/cis-DCE - 3.01 \\
Field blank & neither cis-DCE nor TCE were detected \\
Method blank (3) & neither cis-DCE nor TCE were detected
\end{tabular}

January-February 2002

\begin{tabular}{|c|c|}
\hline Well WJEGTA515 dup & TCE - $51 \mu \mathrm{g} / \mathrm{L} ;$ cis-DCE - $25 \mu \mathrm{g} / \mathrm{L} ; \mathrm{TCE} /$ cis-DCE - 1.51 \\
\hline Well WJEGTA527 dup & TCE - $11 \mu \mathrm{g} / \mathrm{L} ;$ cis-DCE - $40 \mu \mathrm{g} / \mathrm{L} ; \mathrm{TCE} / c i s-\mathrm{DCE}-0.20$ \\
\hline Field blank & neither cis-DCE nor TCE were detected \\
\hline Method blank (3) & neither cis-DCE nor TCE were detected \\
\hline
\end{tabular}

\begin{tabular}{ll}
\hline & \multicolumn{1}{c}{ July 2002 } \\
\hline Well WJEGTA511 dup & TCE - 8.9 $\mu \mathrm{g} / \mathrm{L} ;$ cis-DCE - 48 $\mu \mathrm{g} / \mathrm{L} ; \mathrm{TCE} /$ cis-DCE - 0.14 \\
Well WJEGTA518 dup & TCE - $160 \mu \mathrm{g} / \mathrm{L} ;$ cis-DCE - 25 $\mu \mathrm{g} / \mathrm{L} ; \mathrm{TCE} /$ cis-DCE - 4.72 \\
Field blank & neither cis-DCE nor TCE were detected \\
Method blank (3) & neither cis-DCE nor TCE were detected \\
\hline
\end{tabular}


Prepared by the Texas District Office:

U.S. Geological Survey

8027 Exchange Drive

Austin, TX 78754-4733

Information regarding water resources in Texas is available at URL http: //tx.usgs.gov/ 